UNIVERSIDADE DE SÃO PAULO

FACULDADE DE CIÊNCIAS FARMACÊUTICAS

Programa de Pós-Graduação em Fármaco e Medicamentos

Área de Insumos Farmacêuticos

\title{
Estudo farmacognóstico do jambolão \\ Syzygium cumini (L.) Skeels \\ Myrtaceae
}

ANDREA DE ANDRADE RUGGIERO

Dissertação para obtenção do grau de MESTRE

Orientador: Prof ${ }^{\mathrm{a}} \mathrm{Dr}^{\mathrm{a}}$ Edna Tomiko Myiake Kato

São Paulo

2004 


\section{Andrea de Andrade Ruggiero}

Estudo farmacognóstico do jambolão

Syzygium cumini (L.) Skeels

Myrtaceae

Comissão Julgadora

da

Dissertação para obtenção do grau de Mestre

Profa. Dra. Edna Tomiko Myiake Kato orientador/presidente

$1^{\circ}$. examinador

$2^{\circ}$. examinador

São Paulo, 6̆de 2004. 


\section{AGRADECIMENTOS ESPECIAIS}

Aos meus pais, Edgard e leda, pelo amor e apoio incondicionais.

Ao Claudio, pelo amor e carinho que me dedica.

Aos meus filhos Gustavo, Carolina e Gabriel, pelo tempo cedido durante os últimos quatro anos.

Aos meus irmãos, sogros e cunhados pelo incentivo e compreensão. 


\section{AGRADECIMENTOS}

À Profa Dra Edna Tomiko Myiake Kato pela acolhida em seu grupo de trabalho, orientação para a realização deste trabalho, confiança e amizade.

À Dra Maria Lúcia Kawasaki, pesquisadora do Instituto de Botânica de São Paulo, pela identificação da espécie.

À Profa Dr ${ }^{a}$ Elfriede Marianne Bacchi, pelo apoio, orientação e colaboração nos ensaios de toxicidade aguda.

À Profa Dra Sílvia Berlanga Morais de Barros pela orientação e colaboração na realização do ensaio de atividade antioxidante.

À Profa Dra Mitsuko Taba Ohara e Profa ${ }^{2}{ }^{a}$ Telma Kaneko pela orientação e colaboração na realização do ensaio de atividade antimicrobiana.

Ao Prof. Dr. Paulo Minami pelo uso do fotomicroscópio Nikon ${ }^{\circledR}$.

À $\mathrm{Dr}^{\mathrm{a}}$ Márcia Ortiz Mayo Marques, pesquisadora do Instituto Agronômico Campinas, pela realização da análise por CG-EM do óleo volátil.

Às doutorandas Tânia Cristina Higashi Sawada e Fabiana Gaspar Gonzalez pelo apoio na realização do ensaio de atividade antioxidante.

Aos técnicos, Roberto Honório de Jesus, José Sobrinho e Clarissa Zanoni Kera, pelo apoio nas atividades laboratoriais.

Ao técnico de laboratório de Patologia da Fundação do $A B C$, Juan Francisco Sander Filho, pelos cortes realizados no micrótomo.

Ao farmacêutico Valmir Campiotti do Confar pela realização da análise de determinação do índice de refração.

A todos os funcionários do Bloco 15, com gratidão especial a Beth Paiva (Secretaria de Pós-Graduação), pelo apoio e incentivo dispensado à mirıha pessoa.

Às pós-graduandas Elza Mitiko Okabe, Raquel Donatini, Tati Ishikawa, Vilma Marlene Maciel Mezo, Taís Garcia Dias, Sônia Valéria Bonotto, Helena Onishi Ferraz, Magali Glauzer Silva e Suzana Mayumi Saito, pela colaboração e, principalmente, pela amizade. 
Às graduandas Cely Lee, Claudia Okana, Tatiana Rodrigues Fraga, Monique Santana Torres, Raquel de Traglia Tonini, Thais Tiemi Watanabe, Daniela Marques Gattei, pela ajuda na parte experimental.

Ao CNPQ pela bolsa concedida no período de setembro de 2000 a fevereiro de 2001.

Aos amigos Marcelo Guimarães e José Armando Júnior, pela colaboração e apoio constantes.

Aos demais professores, funcionários, alunos, amigos e colegas, ainda que não citados nominalmente, que direta ou indiretamente colaboraram para a realização deste trabalho. 


\section{SUMÁRIO}

AGRADECIMENTOS ESPECIAIS

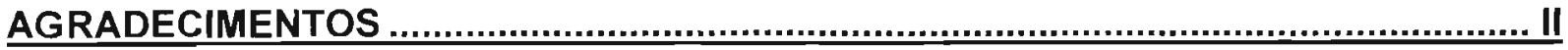

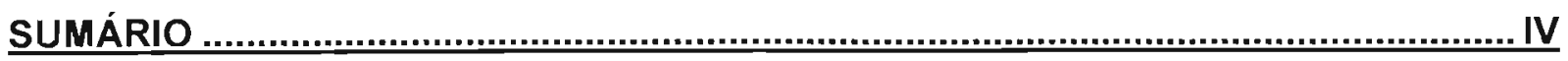

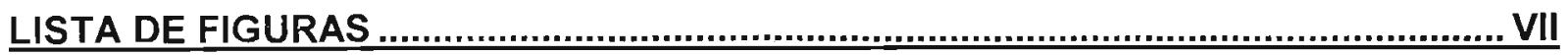

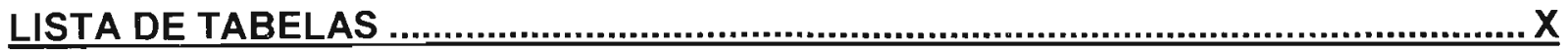

LISTA DE ABREVIATURAS E SÍMBOLOS ....................................................... XII

RESUMO

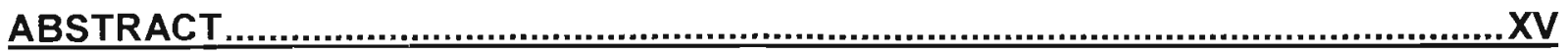

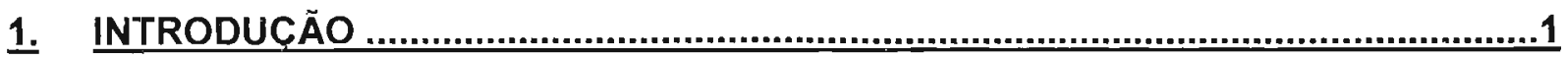

2. ASPECTOS RELEVANTES SOBRE OS GÊNEROS SYZYGIUM E EUGENIA ........2

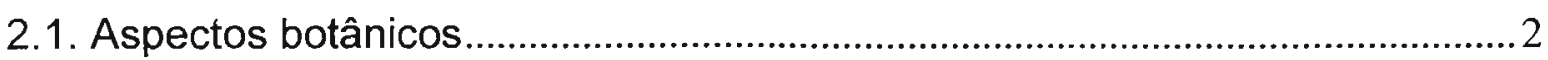

2.1.1. Família Myrtaceae Jussieu ......................................................................... 2

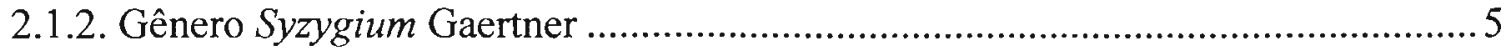

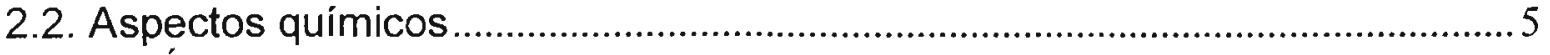

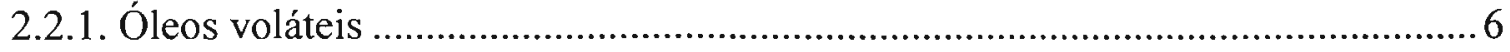

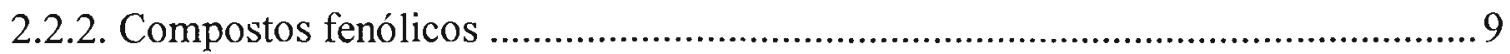

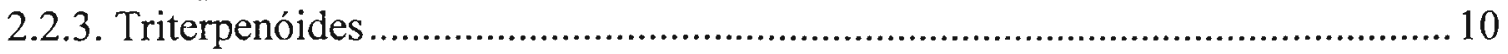

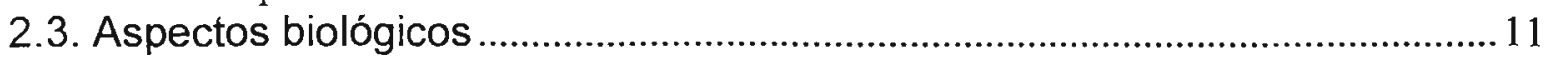

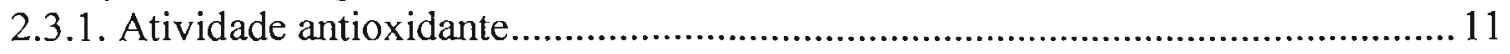

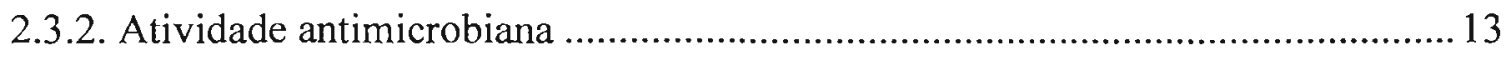

2.4. Espécie Syzygium cumini (L.) Skeels.......................................................... 15

2.4.1. Distribuição geográfica e descrição geral ........................................................... 15

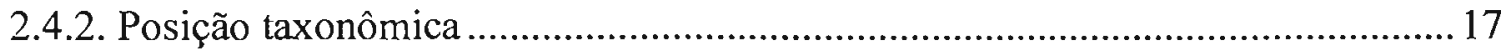

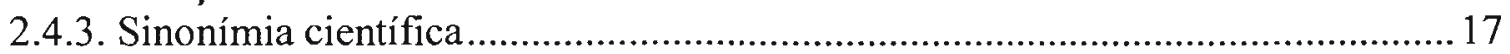

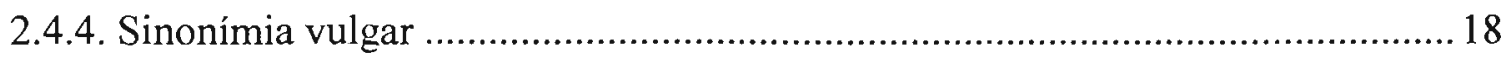

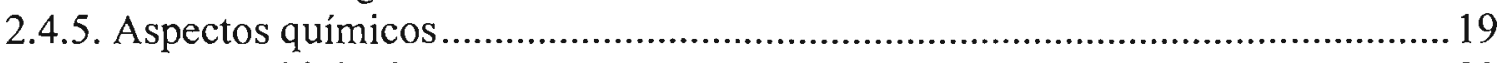

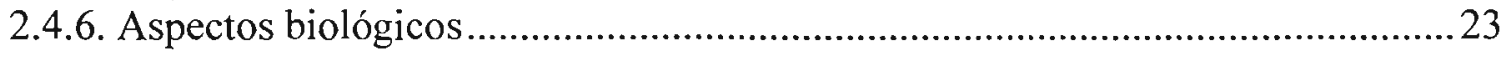

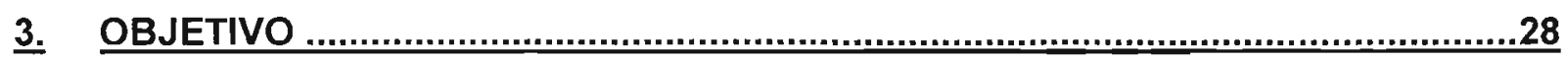

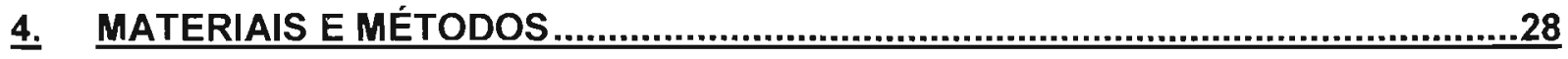




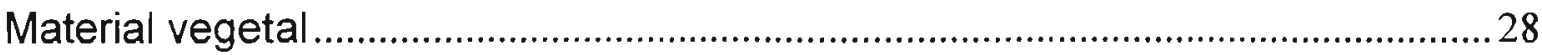

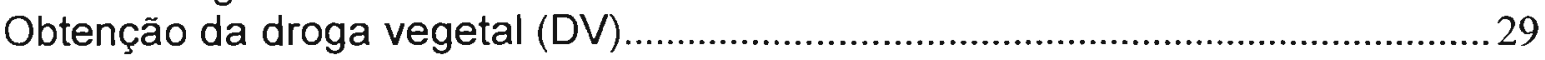

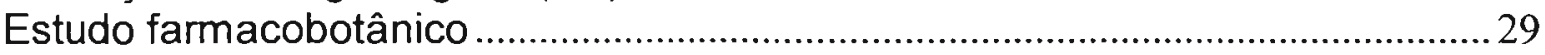

Preparo do extrato hidroetanólico liofilizado (EHEL) ................................................30

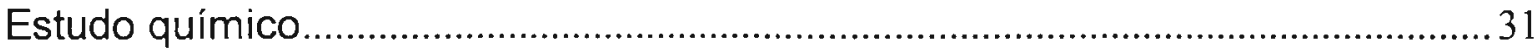

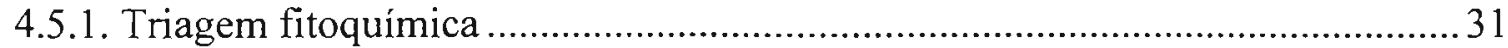

4.5.2. Doseamento dos principais metabólitos secundários presentes ............................37

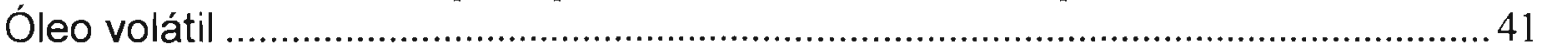

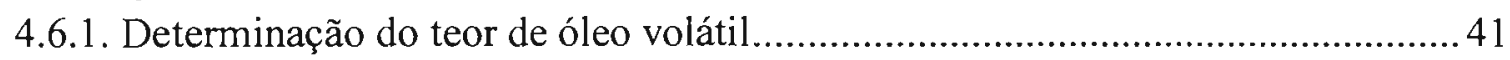

4.6.2. Análise do óleo volátil por cromatografia gasosa ............................................... 41

4.6.3. Determinação do índice de refração .................................................................. 42

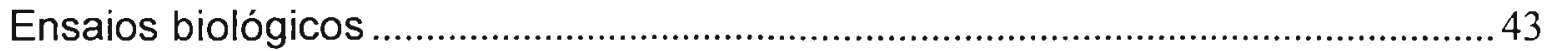

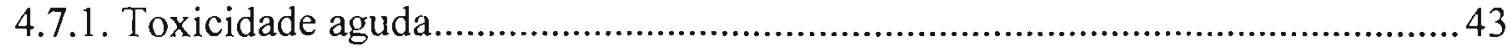

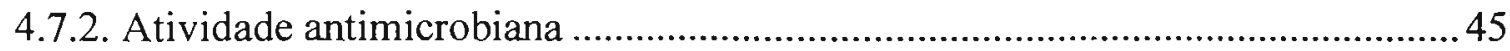

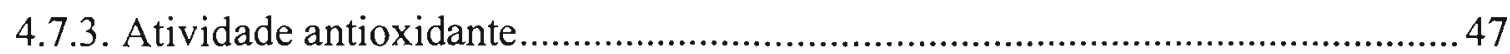

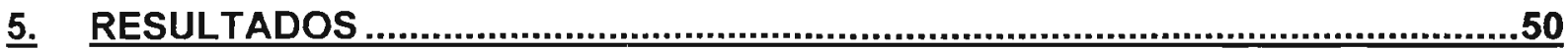

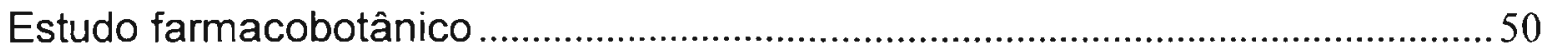

5.1.1. Caracterização macroscópica ..........................................................................50

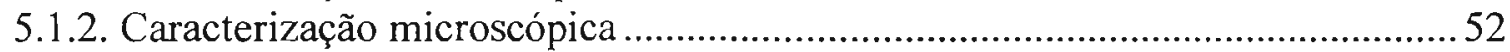

5.1.3. Análise da droga vegetal pulverizada ..........................................................57

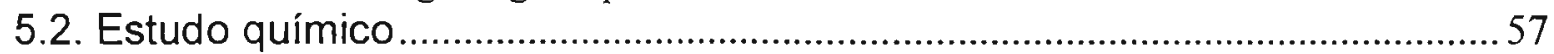

5.2.1. Análise do extrato hidroetanólico liofilizado (EHEL) ………………………....57

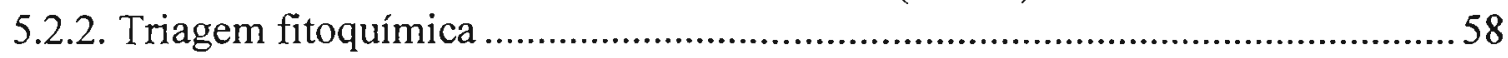

5.2.3. Análise cromatográfica em camada delgada ……………………..................58

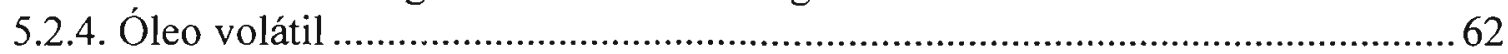

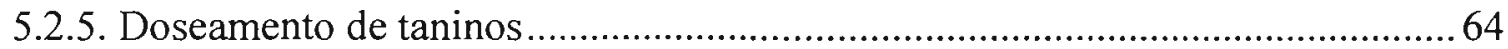

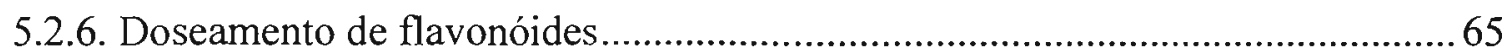

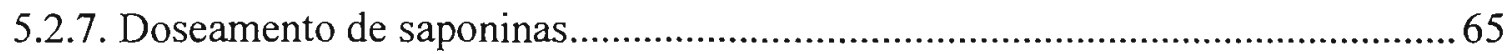

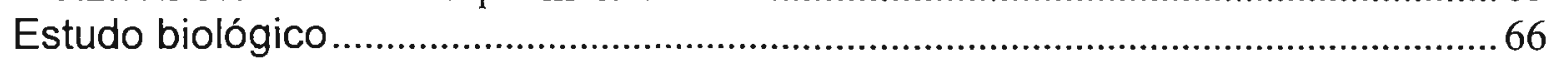

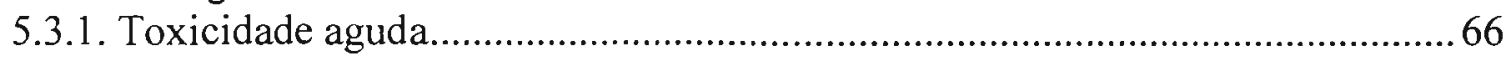

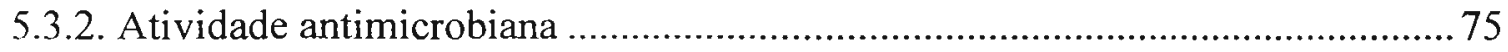

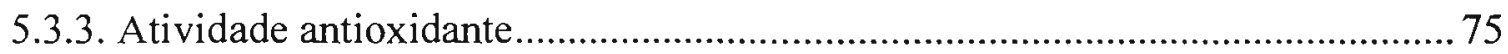

6. DISCUSSÃO

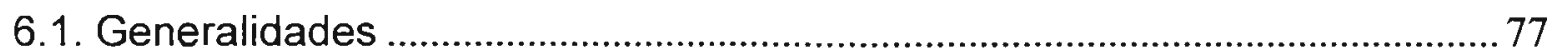

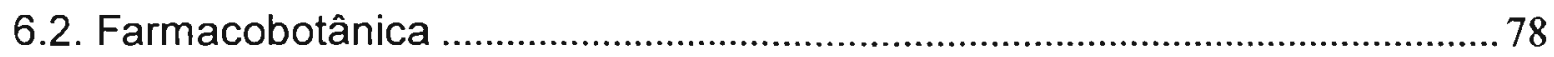

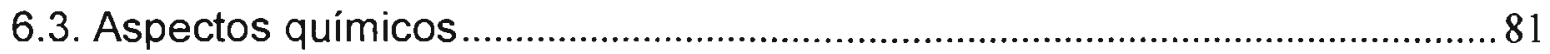

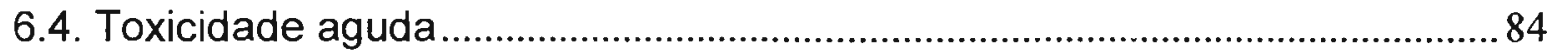

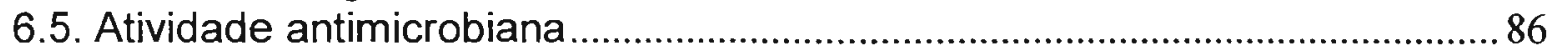

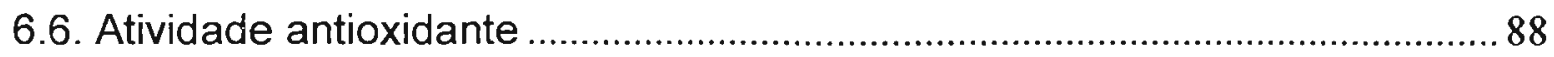

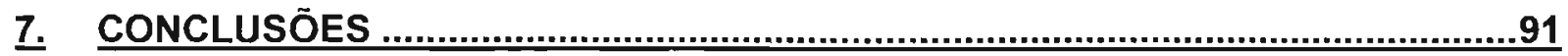




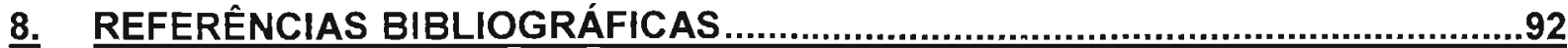




\section{LISTA DE FIGURAS}

Figura 1 - Distribuição das mirtáceas no mundo (HEYWOOD, 1979) ................. 3 Figura 2 - Terpenos encontrados com maior freqüência em óleos voláteis dos gêneros Sygygium e Eugenia (Myrtaceae). 9

Figura 3 - Syzygium cumini (L.) Skeels. A. Hábito. B. Detalhe do ramo. C. Detalhe do ramo florido. D. Detalhe do ramo frutificado. 16

Figura 4 - Reação colorimétrica do ácido tiobarbitúrico (TBA) com malonildialdeído (MDA) para produzir um composto róseo que pode ser determinado espectrofotometricamente a $532-536 \mathrm{~nm}$ 50

Figura 5 - Syzygium cumini (L.) Skeels. Folhas. A. Material vegetal fresco. B. Droga vegetal íntegra. C. Droga vegetal pulverizada. D. Extrato hidroetanólico liofilizado.

Figura 6. Syzygium cumini (L.) Skeels.. Folha. A, B, C e D. Seções transversais. A. mesofilo dorsiventral, com destaque às células coletoras (CC). B. Detalhe do mesofilo, evidenciando drusa de oxalato de cálcio (DR). C. Mesofilo dorsiventral, com destaque à cavidade secretora (CS) e drusas de oxalato de cálcio (DR) no parênquima lacunoso. D. Mesofilo dorsiventral, com destaque às cavidades secretoras (CS) em ambas as faces, parênquima paliçádico (PP) e parênquima lacunoso $(\mathrm{PL})$. Escalas $=20 \mu \mathrm{m}$ para $\mathrm{A}, 10 \mu \mathrm{m}$ para $\mathrm{B}, 40 \mu \mathrm{m}$ para $\mathrm{C}$ e $\mathrm{D}$. .53 Figura 7 - Syzygium cumini (L.) Skeels. Folha. Nervura mediana. A. e B. Secções transversais da nervura mediana, com destaque às cavidades secretoras (CS) e colênquima (CQ). Azul de Astra. C. Detalhe do sistema vascular. Azul de Astra/safranina. Escalas $=20 \mu \mathrm{m}$ para $\mathrm{A}, 10 \mu \mathrm{m}$ para B e $100 \mu \mathrm{m}$ para $\mathrm{C}$.

Figura 8 - Syzygium cumini (L.) Skeels. Folha. A. Vista frontal da face abaxial mostrando estômatos. Escala $=10 \mu \mathrm{m}$. B. Vista frontal da região paliçádica mostrando drusas (DR) e cavidade secretora (CS). Azul de astra. Escala $=20 \mu \mathrm{m} .$.

Figura 9 - Syzygium cumini (L.) Skeels. Folha. Vista frontal da face adaxial, com destaque para as células que recobrem as cavidades secretoras (seta). Azul de astra. Escala $=10 \mu \mathrm{m}$. 
Figura 10: Cromatograma em camada delgada com silicagel - FM: acetato de etila/ácido acético (90:10) - revelador NP/PEG e observação na luz natural.......59 Figura 11: Cromatograma em camada delgada com silicagel - FM: acetato de etila/ácido acético (90:10) - revelador NP/PEG e observação na luz ultravioleta. 59

Figura 12: Cromatograma em camada delgada com celulose - FM: ácido acético $30 \%(100)$ - revelador NP/PEG e observação na luz ultravioleta. .60

Figura 13: Cromatograma em camada delgada com silicagel - FM: clorofórmio/acetona/ácido fórmico $(75: 16,5: 8,5)$ - revelador anisaldeído sulfúrico e observação na luz natural. 61

Figura 14: Cromatograma em camada delgada com silicagel - FM: clorofórmio/acetona/ácido fórmico $(75: 16,5: 8,5)$ - revelador vanilina sulfúrica e observação na luz natural. 61

Figura 15: Cromatograma em camada delgada com silicagel - FM: tolueno/acetato de etila (93:7) - revelador varilina sulfúrica e observação na luz natural.

Figura 16: Cromatograma em camada delgada com silicagel - FM: tolueno/acetato de etila (93:7) - revelador anisaldeído sulfúrico e observação na luz natural........63 Figura 17: Cromatograma em fase gasosa do óleo volátil das folhas frescas de Syzygium cumini (L.) Skeels.

Figura 18 - Evolução da massa média corpórea dos camundongos fêmeas, controle e teste tratadas por via oral com extrato EHEL de $S$. cumini na dose de $5 \mathrm{~g} / \mathrm{kg}$ de peso de animal, no ensaio de toxicidade aguda $(n=4)$.

Figura 19 - Evolução da massa média corpórea dos camundongos machos, controle e teste tratados por via oral com extrato EHEL de $S$. cumini na dose de $5 \mathrm{~g} / \mathrm{kg}$ de peso de animal, no ensaio de toxicidade aguda $(n=5)$. 68 Figura 20 - Comparação do consumo médio de ração por animal dos camundongos fêmeas, controle e teste tratadas por via oral com extrato EHEL de $S$. cumini na dose de $5 \mathrm{~g} / \mathrm{kg}$ de peso de animal, no ensaio de toxicidade aguda $(n=4)$.

Figura 21 - Comparação do consumo médio de ração por animal dos camundongos machos, controle e teste tratados por via oral com extrato EHEL de 
S. cumini na dose de $5 \mathrm{~g} / \mathrm{kg}$ de peso de animal, no ensaio de toxicidade aguda $(n=5)$ .70

Figura 22 - Comparação do consumo médio de água por animal dos camundongos fêmeas, controle e teste tratadas por via oral com extrato EHEL de S. cumini na dose de $5 \mathrm{~g} / \mathrm{kg}$ de peso de animal, no ensaio de toxicidade aguda $(n=4)$ 71

Figura 23 - Comparação do consumo médio de água por animal dos camundongos machos, controle e teste tratados por via oral com extrato EHEL de S. cumini na dose de $5 \mathrm{~g} / \mathrm{kg}$ de peso de animal, no ensaio de toxicidade aguda $(n=5)$

Figura 24 - Comparação da massa média dos órgãos dos camundongos fêmeas, controle e teste tratadas por via oral com extrato EHEL de $S$. cumini na dose de $5 \mathrm{~g} / \mathrm{kg}$ de peso de animal, no ensaio de toxicidade aguda $(\mathrm{n}=4)$. .73 Figura 25 - Comparação da massa média dos órgãos dos camundongos machos, controle e teste tratados por via oral com extrato EHEL de S. cumini na dose de $5 \mathrm{~g} / \mathrm{kg}$ de peso de animal, no ensaio de toxicidade aguda $(n=5)$.

Figura 26 - Cromatograma em camada delgada com silicagel - FM: clorofórmio/acetona/ácido fórmico $(75: 16,5: 8,5)$ - revelador betacaroteno e observação na luz natural. .76

Figura 27 - Capacidade antioxidante do extrato hidroetanólico liofilizado (EHEL) de $S$. cumini pelo método da formação de MDA em homogenato de cérebro de ratos 


\section{LISTA DE TABELAS}

Tabela 1 - Constituintes químicos de óleos voláteis em espécies pertencentes aos gêneros Syzygium e Eugenia (Myrtaceae)..

Tabela 2 - Compostos fenólicos em espécies pertencentes aos gêneros Syzygium e Eugenia (Myrtaceae).

Tabela 3 - Triterpenóides em espécies pertencentes aos gêneros Syzygium e Eugenia (Myrtaceae)

Tabela 4 - Substâncias quimicas identificadas em Syzygium cumini (L.) Skeels (Myrtaceae)

Tabela 5 - Triagem fitoquímica realizada com droga vegetal e com o extrato hidroetanólico liofilizado de S. cumini (L.) Skeels.

Tabela 6 - Composição quimica do óleo volátil das folhas frescas de S. cumini (L.)

Skeels e abundância relativa.

Tabela 7 - Teor de taninos totais na droga vegetal e no EHEL de S. cumini (L.)

Skeels.

Tabela 8 - Teor de flavonóides totais na droga vegetal e no EHEL de S. cumini (L.)

Skeels.

Tabela 9 - Teor de saponinas totais na droga vegetal e no EHEL de S. cumini (L.) Skeels.

Tabela 10 - Massa corpórea média dos camundongos fêmeas, controle e teste tratadas por via oral com extrato EHEL de S. cumini na dose de $5 \mathrm{~g} / \mathrm{kg}$ de peso de animal, no ensaio de toxicidade aguda $(n=4)$

Tabela 11 - Massa corpórea média dos camundongos machos, controle e teste tratados por via oral com extrato EHEL de $S$. cumini na dose de $5 \mathrm{~g} / \mathrm{kg}$ de peso de animal, no ensaio de toxicidade aguda $(n=5)$.

Tabela 12 - Consumo médio de ração por animal dos camundongos fêmeas, controle e teste tratadas por via oral com extrato EHEL de $S$. cumini na dose de $5 \mathrm{~g} / \mathrm{kg}$ de peso de animal, no ensaio de toxicidade aguda $(\mathrm{n}=4)$ 69 
Tabela 13 - Consumo médio de ração por animal dos camundongos machos, controle e teste tratados por via oral com extrato EHEL de S. cumini na dose de $5 \mathrm{~g} / \mathrm{kg}$ de peso de animal, no ensaio de toxicidade aguda $(\mathrm{n}=5)$. 70 Tabela 14 - Consumo médio de água por animal dos camundongos fêmeas, controle e teste tratadas por via oral com extrato EHEL de S. cumini na dose de $5 \mathrm{~g} / \mathrm{kg}$ de peso de animal, no ensaio de toxicidade aguda $(\mathrm{n}=4)$. 71 Tabela 15 - Consumo médio de água por animal dos camundongos machos, controle e teste tratados por via oral com extrato EHEL de S. cumini na dose de $5 \mathrm{~g} / \mathrm{kg}$ de peso de animal, no ensaio de toxicidade aguda $(\mathrm{n}=5)$. 72 Tabela 16 - Massa média dos órgãos dos camundongos fêmeas, controle e teste tratadas por via oral com extrato EHEL de $S$. cumini na dose de $5 \mathrm{~g} / \mathrm{kg}$ de peso de animal, no ensaio de toxicidade aguda $(n=4)$. 73 Tabela 17 - Massa média dos órgãos dos camundongos machos, controle e teste tratados por via oral com extrato EHEL de $S$. cumini na dose de $5 \mathrm{~g} / \mathrm{kg}$ de peso de animal, no ensaio de toxicidade aguda $(n=5)$. .74 Tabela 18 - Atividade antimicrobiana do EHEL das folhas de S. cumini pelo método de diluição em meio líquido em tubos. .75 Tabela 19 - Médias aritméticas e os desvios padrão da determinação da capacidade antioxidante (CAOx) do EHEL das folhas de S. cumini (L.) Skeels....76 


\section{LISTA DE ABREVIATURAS E SÍMBOLOS}

ACE Extrato fracionado com acetato de etila

BHT Butilhidroxitolueno

C Concentração

CAOX Capacidade antioxidante

CG-EM Cromatografia gasosa acoplada à espectrômetro de massa

CIM Concentração inibitória mínima

CNS Conselho Nacional de Saúde

DCM Extrato fracionado com diclorometano

DNA Ácido desoxirribonucléico

DV Droga vegetal

EHE Extrato hidroetanólico

EHEL Extrato hidroetanólico liofilizado

ETA Extrato fracionado com etanol $70 \%$

FM Fase móvel

L. Linnaeus ou Linné

MDA Malonildialdeído

MG Minas Gerais

MS Ministério da Saúde

n-BUT Extrato fracionado com $n$-butanol

NP/PEG Reagente produtos naturais / polietilenoglicol

PNA Polifenóis não adsorvidos

PT Polifenóis totais

p/p Peso por peso

$\mathrm{p} / \mathrm{P} \quad$ Peso por volume

RDC Resolução da Diretoria Colegiada

Rf Fator de retenção

SM Solução mãe

SNVS Secretaria Nacional de Vigilância Sanitária

$s p \quad$ Espécie do gênero mencionado

SP São Paulo 
TBA Ácido tiobarbitúrico

TCA Ácido tricloroacético

UFC Unidades formadoras de colônia

VN Volume por volume 


\section{RESUMO}

Syzygium cumini (L.) Skeels (Myrtaceae) encontra uso na medicina tradional como hipoglicemiante. Folhas mostram emprego adicional, no tratamento de úlceras pépticas, diarreias e hemorróidas. A dissertação apresenta descrições macro e microscópicas das folhas, acompanhadas de fotografias. Teores de flavonóides, saponinas e taninos foram determinados no extrato hidroetanólico liofilizado e na droga coletada no verão e outono. O óleo volátii foi analisado. O extrato foi avaliado quanto à atividade antimicrobiana, antioxidante e toxicidade aguda. Os flavonóides $(0,53 \%-0,62 \%)$, saponinas $(4,22 \%-8,64 \%)$ e taninos $(3,47$ $4.15 \%)$ apresentaram teores elevados no outono. No extrato, teores de flavonóides, saponinas e taninos foram de $2,19 \%, 10,92 \%$ e $13.97 \%$, respectivamente. $\alpha$-pineno, $\alpha$-terpineol, $\beta$-pineno e limoneno foram os componentes majoritários do óleo. O extrato não reveiou sinais de toxicidade aguda, e não apresentou atividade contra bactérias e fungos até $1.000 \mu \mathrm{g} / \mathrm{mL}$. O extrato apresentou atividade antioxidante. Os dados obtidos contribuem para melhor conhecimento da espécie e no controle de qualidade. 


\begin{abstract}
Syzygium cumini (L.) Skeels (Myrtaceae) is a hipoglycemic in folk medicine. Its leaves are also used as anti-ulcer, anti-diarrheic and antinemorrhoid. This work brings macro and microscopic descriptions of the leaves, with photos. Flavonoids, saponins and tannins contents were determinated in the liophylizated hydroethanolic extract and in the drug collected in summer and fall. The volatile oil was analysed. The antimicrobial and antioxidant activities and the acute toxicity were avaliated. The flavonoids $(0.53 \%-0.62 \%)$, saponins $(4.22 \%-8.64 \%)$ and tannins (3.47\%-4-15\%) showed their highest values in the fall sample. The contents of flavonoids, saponins and tannins in the extract were. $2.19 \%$, $10.92 \%$ and $13.97 \%$, rescpectively. $\alpha$-pinene, $\alpha$-terpineol, $\beta$-pinene and limonene were the major constituents of the oil. The extract showed no signs of acute toxicity nor was it active against bacteria and funghi up to $1,000 \mu \mathrm{g} / \mathrm{mL}$. The extract showed antioxidant activity. These data contribute for a better knowledge of the specie and quality control.
\end{abstract}




\section{INTRODUÇÃO}

A familia Myrtaceae Jussieu compreende cerca de 100 gêneros e 3.000 espécies distribuídos por países tropicais e subtropicais. especialmente nas Américas, Austrália, ocorrendo poucas espécies nas regiōes temperadas. A maioria das mirtáceas é constituída por plantas lenhosas, arbustivas ou arbóreas. Contêm numerosas cavidades secretoras subepidérmicas de óleos voláteis, que podem ser observadas sob a forma de pequenos pontos translúcidos nas folhas e flores (HEYWOOD, 1979; BARROSO, 1984).

A importância econômica provém, principalmente, das espécies de Eucalyptus, de alguns condimentos e dos gêneros que produzem frutos comestiveis. São amplamente utilizados os condimentos Syzygium aromaticum (L.) Merril \& Perry (cravo-da-india) e Pimenta dioica (L.) Merril (pimenta-da-jamaica).

Entre os frutos mais conhecidos, podem-se citar os provenientes dos gêneros: Eugenia (pitanga), Psidium (goiaba), Myrciaria (jaboticaba), Campomanesia (guabiroba) e Syzygium (jambolão e jambo). Algumas espécies também são cultivadas como ornamentais destacando-se, entre elas, Myrtus communis L., a única espécie européia da familia (LAWRENCE, 1966; KAWASAKI, 1984).

A espécie Syzygium cumini (L.) Skeels, popularmente conhecida como jambolão e objeto de estudo desta dissertação, é uma árvore de aproximadamente 10 metros de altura. Sua larga, densa e bem formada copa, oferece sombra, motivo pelo qual é freqüentemente cultivada como árvore ornamental nas proximidades das habitações, assim como pelos seus frutos comestíveis, porém em geral pouco apreciados. Em Belo Horizonte (MG), o jambolão foi experimentado na arborização urbana, tendo sido logo abolido pelas manchas que seus frutos deixavam nos 
calçamentos das ruas e pinturas dos automóveis (LEGRAND e KLEIN, 1978).

Na medicina popular, o pó das sementes é utilizado tradicionalmente como hipoglicemiante, sendo também empregados, com menor freqüência, os frutos, cascas e folhas (OLIVEIRA e SAITO, 1987/1989).

As folhas também são utilizadas como recurso terapêutico no tratamento de úlceras pépticas, diarréias e de hemorróidas por sua adstringência devida à presença de taninos (LEGRAND e KLEIN, 1978; CORREA, 1984; OLIVEIRA e SAITO, 1987/1989).

A possibilidade de contribuir na padronização da droga constituída de folhas, do extrato liofilizado preparado com as folhas e do óleo volátil da espécie Syzygium cumini motivou o estudo desta espécie, de modo a poder incluí-la futuramente na Farmacopéia Brasileira como droga vegetal.

\section{ASPECTOS RELEVANTES SOBRE OS GENNEROS Syzygium E Eugenia}

As observações apresentadas a seguir mencionam os aspectos botânicos, químicos, farmacológicos e usos da família Myrtaceae, gênero Syzygium e da espécie Syzygium cumini, destacando-se as atividades biológicas ensaiadas. Inclui, também, informaçōes sobre o gênero Eugenia e as espécies sinonimizadas apresentadas no subitem 2.4.3.

\subsection{Aspectos botânicos}

\subsubsection{Família Myrtaceae Jussieu}

A familia Myrtaceae está incluída na ordem Myrtales, sendo constituída de plantas lenhosas, arbustivas ou arbóreas, (DAHLGREN, 1980; TAKHTAJAN, 1980; CRONQUIST, 1981). Está distribuída, principalmente, 
nas regiōes tropicais e subtropicais do planeta. Os dois centros principais de concentração estão na América e no leste e sudoeste da Austrália (HEYWOOD, 1979). Os gêneros com maiores números de espécies são Eucalyptus (500 espécies aproximadamente), Eugenia (400), Myrcia (400) e Syzygium (300) (JUDD, 1999).

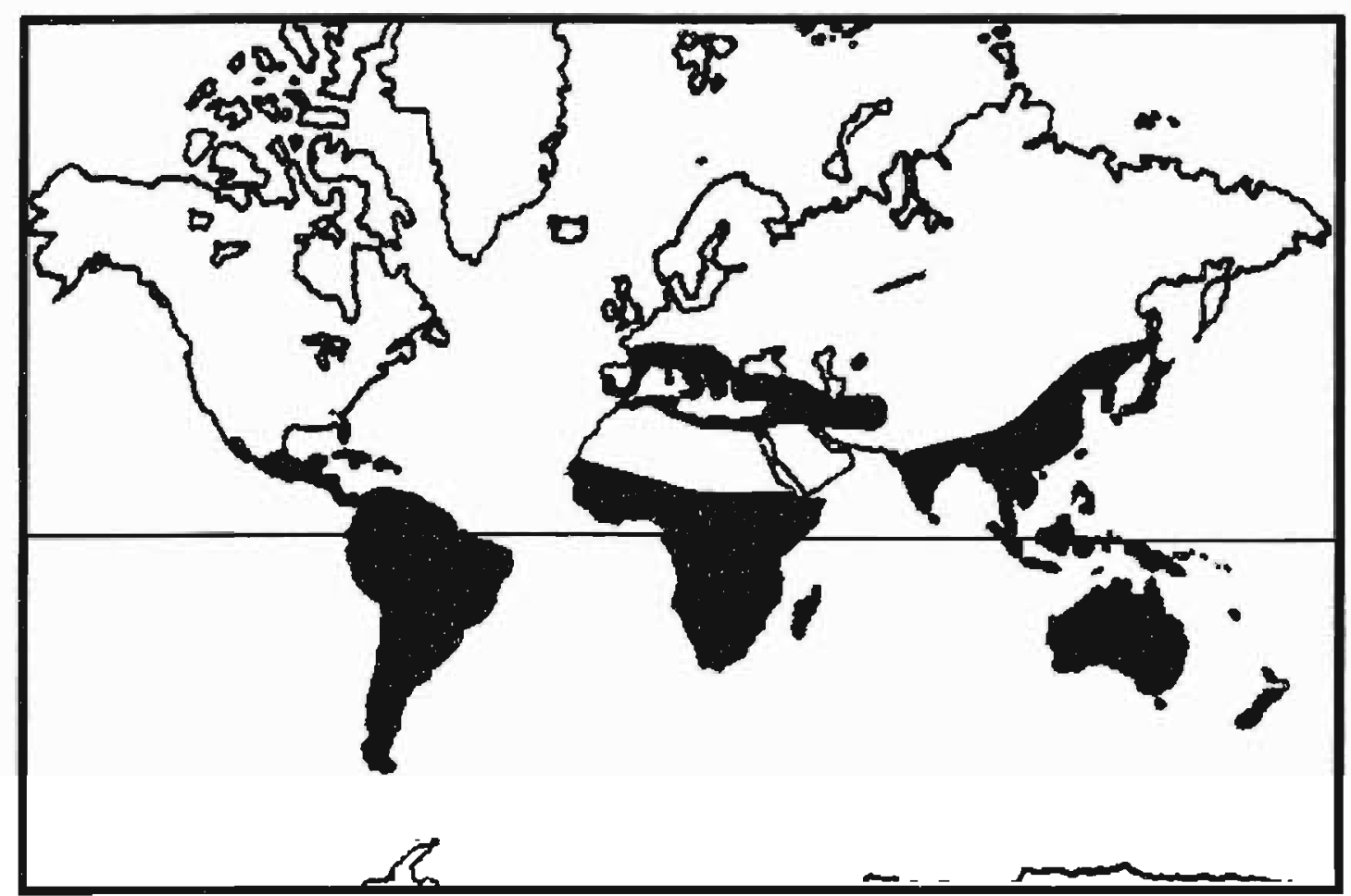

Figura 1 - Distribuição das mirtáceas no mundo (HEYWOOD, 1979).

A família Myrtaceae é dividida, tradicionalmente, em duas subfamílias: Leptospermoideae e Myrtoideae (DAHLGREN, 1980; TAKHTAJAN, 1980; CRONQUIST, 1981; LANDRUM e KAWASAKI, 1997).

A subfamilia Leptospermoideae reúne as espécies com fruto seco encontradas, principalmente, na Austrália e Polinésia, tais como as pertencentes aos gêneros Callistemon, Eucalyptus e Melaleuca (KAWASAKI, 1984).

A subfamília Myrtoideae inclui as espécies com fruto carnoso encontradas, principalmente nas Américas tropical e subtropical e pertencentes, por 
exemplo, aos gêneros Eugenia, Myrcia, Psidium e Syzygium (KAWASAKI, 1984).

O embrião das sementes das Mirtáceas oferece amplo campo de investigação e tem servido de base para a classificação em tribos e subtribos. Segundo Landrum e Kawasaki (1997), as mirtáceas com frutos carnosos e ovário ínfero dividem-se em três subtribos: Myrciinae, Eugeniinae e Myrtinae. O gênero Syzygium, que não é nativo do Brasil, pertence à subtribo Eugeniinae (LEGRAND e KLEIN, 1978).

Segundo Metcalfe e Chalk (1950), os caules de plantas pertencentes a Myrtaceae caracterizam-se pela presença de floema intraxilemático e pontoações areoladas guarnecidas. Estes autores descrevem nesta familia a ocorrência de taninos e cristais de oxalato de cálcio nas células parenquimáticas; folhas hipoestomáticas, em geral, providas de estômatos anomocíticos e o mesofilo dorsiventral.

Numerosas cavidades secretoras ocorrem nos ramos jovens, nas folhas, flores, frutos e sementes (METCALFE e CHALK, 1950; CRONQUIST, 1981; KAWASAKI, 1984).

As folhas são simples e freqüentemente opostas, de bordos inteiros, peninérveas, geralmente com nervura central impressa ou saliente na face abaxial e nervuras laterais anastomosadas em arcos nos bordos foliares, formando uma nervura marginal simples ou dupla. As inflorescências são axilares ou terminais, em racemos, cimeiras, panículas, fascículos ou dicásios com brácteas e bractéolas persistentes ou decíduas. Mais raramente, as flores apresentam-se solitárias e axilares. As flores são geralmente monóclinas e actinomorfas (KAWASAKI, 1984). 


\subsubsection{Gênero Syzygium Gaertner}

O gênero Syzygium compreende cerca de 75 espécies distribuídas no sudeste da Ásia. S. cumini (jambolão) e S. jambos (jambo) são as duas espécies mais conhecidas pelos frutos édulos e, $S$. aromaticum (cravo-daíndia) pela importância comercial. Estas espécies, no passado, foram descritas como pertencentes ao gênero Eugenia. Espécies de Syzygium e de Eugenia foram separadas considerando caracteres técnicos. Syzygium apresenta flores reunidas em cimeiras, hipanto prolongado, confundindo-se com o pedicelo, cotilédones livres e testa áspera aderida ao pericarpo (BAILEY, 1951; SCHMID, 1972, LEGRAND e KLEIN, 1978). Eugenia é o maior gênero de Myrtaceae da América tropical, reunindo cerca de 500 espécies arbóreas ou arbustivas, providas de flores tetrâmeras, com sépalas diferenciadas no botão floral, hipanto pouco ou não prolongado sobre o ovário, embrião indiviso, com os cotilédones concrescidos (KAWASAKI, 1984).

Sob o aspecto anatômico, o lenho dos dois gêneros parecem distintos. As espécies de Syzygium geralmente mostram-se glabras e providas de numerosas drusas. Syzygium tende a ser moderada a fortemente tanífera e Eugenia, apenas ligeiramente, fato que sugere diferenças químicas (SCHMID, 1972).

\subsection{Aspectos químicos}

Em razão do elevado número de representantes em Myrtaceae, na revisão da composição química da família mereceram destaque os gêneros Syzygium e Eugenia. 


\subsection{1. Óleos voláteis}

Os óleos essenciais ou voláteis são comumente encontrados em angiospermas dicotiledôneas, tais como, Asteraceae, Apiaceae, Lamiaceae, Lauraceae, Myrtaceae, Myristicaceae, Piperaceae, Rutaceae, entre outras. Em monocotiledôneas, as famílias Poaceae e Zingiberaceae merecem destaque (SIMŌES e colaboradores, 2003). Este grupo de compostos, diversas vezes, ocorre em estruturas secretoras características de cada familia, bem como, em maior proporção em determinados órgãos. Em Apiaceae, esses óleos encontram-se em dutos secretores. Em Lamiaceae, observam-se tricomas glandulares em folhas e caules jovens. Em Myrtaceae, apresentam-se em cavidades secretoras, principalmente em folhas (METCALFE e CHALK, 1950).

Os componentes que ocorrem em maior concentração nos óleos voláteis são importantes para sua atividade biológica. Alterações climáticas e edáficas influenciam em sua composição química. Robles e Garzino (2000) relacionam a variabilidade química do óleo volátil de Cistus monspeliensis cultivada em diferentes substratos.

Aceita-se que a função biológica dos óleos voláteis esteja relacionada com o papel ecológico. Os óleos voláteis de Eucalyptus globulus atuam como agentes alelopáticos (HARBONE, 1988).

Sob o ponto de vista farmacológico, aos óleos voláteis são atribuídas atividades antifúngica, antiviral, antiinflamatória, anti-séptica, entre outras (BENENCIA e COURREGES, 2000; DE BILLERBECK e colaboradores, 2001; SIMŌES e colaboradores, 2003). A toxicidade dos óleos voláteis está relacionada a dermatites de contato, sendo mencionado que a atividade acentua-se com a elevação do teor de componentes insaturados (SIMÕES e colaboradores, 2003). 
Os óleos voláteis, constituídos na maioria das vezes por terpenóides, caracterizam-se pela volatilidade e aroma agradável. Os terpenóides constituem uma grande variedade de substâncias vegetais, formadas de unidades do isopreno que, por sua vez, origina-se a partir da via do mevalonato. Os compostos mais freqüentes nos óleos voláteis são os monoterpenos e os sesquiterpenos. Sua utilização na indústria farmacêutica, cosmética e alimentícia é bem conhecida (SIMÕES e colaboradores, 2003). A familia Myrtaceae tem nas espécies de Eucalyptus os principais representantes na obtenção comercial dos mesmos. O óleo de eucalipto está inscrito em muitas farmacopéias, inclusive na quarta edição da Farmacopéia Brasileira (1996). Botões florais de cravo-da-índia (Syzygium aromaticum) são ricos em eugenol que possui ação anestésica local e anti-séptica (SIMÕES e colaboradores, 2003), tendo sido incluído em 2002 na quarta edição da Farmacopéia Brasileira. A goiabeira (Psidium guajava) com $0,2 \%$ de óleo volátil, também da família Myrtaceae, foi incluida em 2002 na quarta edição da Farmacopéia Brasileira. 
Tabela 1 - Constituintes químicos de óleos voláteis em espécies pertencentes aos gêneros Sygygium e Eugenia (Myrtaceae).

\begin{tabular}{|c|c|c|}
\hline Espécie vegetal & Substância química & $\begin{array}{c}\text { Referências } \\
\text { bibliográficas }\end{array}$ \\
\hline E. banderensis & T-muurolol & BELLO e cols., 1995 \\
\hline E. dysenterica & $\begin{array}{l}\beta \text {-cariofileno, óxido } \quad \text { de } \\
\text { cariofileno, } \alpha \text {-terpineol, } \alpha- \\
\text { humuleno e limoneno. }\end{array}$ & COSTA e cols., 2000 \\
\hline E. heyeneana & $\alpha$-pineno & GARG e NIGAM, 1970 \\
\hline E. nitida & $\begin{array}{l}\text { Germacreno-D-4-ol; } \\
\text { elemeno; } \beta \text {-cariofileno }\end{array}$ & MARTINS e cols., 1999 \\
\hline E. ovalifolia & Globulol; viridifloral & GODOY e cols., 1999 \\
\hline E. punicifolia & $\begin{array}{l}\beta \text {-cariofileno; } y \text {-elemeno; } \delta \text { - } \\
\text { cadineno; } \alpha \text {-humuleno; } \alpha- \\
\text { copaeno }\end{array}$ & MAIA e cols., 1997 \\
\hline E. uniflora & $\begin{array}{l}\text { Selina-1,3,7(11)-trien-8-ona; } \\
\text { oxidoselina-1,3,7(11)-trien-8- } \\
\text { ona; furanodieno }\end{array}$ & $\begin{array}{l}\text { WEYERSTAHL e cols., } \\
\text { 1988; EL-SHABRAWY e } \\
\text { cols., 1995; MORAIS e } \\
\text { cols., } 1996\end{array}$ \\
\hline E. uruguayensis & $\begin{array}{l}\text { a-pineno; limoneno; } 1,8- \\
\text { cineol e óxido de cariofileno. }\end{array}$ & $\begin{array}{l}\text { DELLACASSA e cols., } \\
1997\end{array}$ \\
\hline S. aromaticum & $\begin{array}{l}\text { Eugenol, acetato de } \\
\text { eugenol, } \quad \beta \text {-cariofileno, } \\
\text { óxido de cariofileno e } \alpha \text { - } \\
\text { humuleno }\end{array}$ & ZHENG e cols., 1992 \\
\hline S. jambos & a-pineno, limoneno & $\begin{array}{l}\text { NARASIMHA-RAO } \\
\text { NIGAM, } 1969\end{array}$ \\
\hline
\end{tabular}


<smiles>CC1=CCC2CC1C2(C)C</smiles>

$\alpha$-pineno<smiles>C=C(C)C1CC=C(C)CC1</smiles>

limoneno<smiles>C=C1CCC2CC1C21CC1</smiles>

$\beta$-pineno

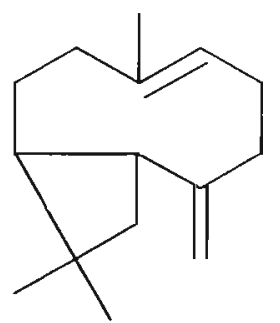

$\beta$-cariofileno<smiles>C=CCc1ccc(O)c(OC)c1</smiles>
eugenol

Figura 2 - Terpenos encontrados com maior freqüência em óleos voláteis dos gêneros Syzygium e Eugenia (Myrtaceae).

\subsubsection{Compostos fenólicos}

O termo compostos fenólicos compreende substâncias que apresentam, em comum, anel aromático com uma ou mais hidroxilas. Neste grupo incluem-se os flavonóides, os fenilpropanóides, as quinonas fenólicas, os ácidos fenólicos, as ligninas e os taninos, entre outros. Unidades fenólicas são ocasionalmente encontradas em alcalóides e terpenóides (HARBONE, 1991). Os compostos fenólicos podem ser formados através de duas rotas biossintéticas: pela via do ácido chiquímico a partir de carboidratos, ou pela via do acetato-polimalato que inicia com acetil-coenzima $A$ e malonil-coenzima $A$. Pela via do ácido chiquímico obtém-se compostos com hidroxilas na posição orto, que se formam a partir do ácido cinâmico. Por outro lado, a via do acetatopolimalato origina compostos com grupos hidroxilas dispostos em meta (SIMÕES e colaboradores, 2003). A familia Myrtaceae caracteriza-se pela presença de taninos e flavonóides (METCALFE e CHALK, 1950). 
Tabela 2 - Compostos fenólicos em espécies pertencentes aos gêneros Syzygium e Eugenia (Myrtaceae).

\begin{tabular}{|c|c|c|c|}
\hline $\begin{array}{l}\text { Espécie } \\
\text { vegetal }\end{array}$ & Substância química & $\begin{array}{l}\text { Órgão } \\
\text { vegetal }\end{array}$ & $\begin{array}{c}\text { Referências } \\
\text { bibliográficas }\end{array}$ \\
\hline E. grandis & $\begin{array}{l}\text { Castalgina, vescalgina, } 1-0- \\
\text { galoilcastalgina }\end{array}$ & Folhas & $\begin{array}{l}\text { NONAKA e cols., } \\
1987\end{array}$ \\
\hline E. pyriformis & Quercetina, rutina e miricitrina & Folhas & $\begin{array}{l}\text { SCHMEDA- } \\
\text { HIRSCHMANN, } \\
1995\end{array}$ \\
\hline E. punicifolia & $\begin{array}{l}\text { Quercetina, rutina, miricetina, } \\
\text { miricitrina }\end{array}$ & Folhas & $\begin{array}{l}\text { SCHMEDA- } \\
\text { HIRSCHMANN, } \\
1995\end{array}$ \\
\hline E. uniflora & $\begin{array}{l}\text { Quercitrina, quercetina, } \\
\text { miricitrina, miricetina, taninos } \\
\text { (eugenifloinas D1 e D2) }\end{array}$ & Folhas & $\begin{array}{l}\text { SCHMEDA- } \\
\text { HIRSCHMANN e } \\
\text { cols., 1987; LEE } \\
\text { e cols., } 1997\end{array}$ \\
\hline S. aromaticum & Taninos & Folhas & $\begin{array}{l}\text { TANAKA e cols., } \\
1993\end{array}$ \\
\hline
\end{tabular}

\subsubsection{Triterpenóides}

Triterpenos são compostos com 30 átomos de carbono, formados biossinteticamente de seis unidades isopreno. A diversidade estrutural é grande, sendo conhecidos na atualidade mais de 4.000 terpenóides isolados de vegetais. Este grupo de substâncias pode ocorrer na forma livre ou combinada com açúcares. Os triterpenóides livres são componentes comumente encontrados em resinas, látex e na composição da camada cuticular. Na forma glicosilada são designados de saponinas triterpênicas. Do ponto de vista ecológico, os triterpenóides de sabor amargo são considerados como meio de defesa contra herbivoria; e, as saponinas tóxicas a animais de sangue frio, como os peixes (ROBBERS e 
colaboradores, 1997; SIMÕES e colaboradores, 2003). Dentre as diversas propriedades atribuídas às saponinas, destacam-se a ictiotóxica, hemolitica, antiinflamatória, adaptogênica, mucoprotetora e antifúngica (FAVEL e colaboradores, 1994; SIMÕES e colaboradores, 2003). Além disso, nos estágios finais da biossíntese podem ser retirados pequenos fragmentos de carbono para produzir moléculas com menos de trinta átomos de carbono, como por exemplo os esteróides com 27 átomos de carbono (ROBBERS e colaboradores, 1997). Os triterpenóides isolados de espécies de Myrtaceae encontram-se discriminados na tabela 3.

Tabela 3 - Terpenóides em espécies pertencentes aos gêneros Syzygium e Eugenia (Myrtaceae).

\begin{tabular}{|c|c|c|c|}
\hline $\begin{array}{l}\text { Espécie } \\
\text { vegetal }\end{array}$ & Substância química & $\begin{array}{l}\text { Órgão } \\
\text { vegetal }\end{array}$ & $\begin{array}{c}\text { Referência } \\
\text { bibliográfica }\end{array}$ \\
\hline S. buxifolium & $\begin{array}{l}\text { Friedelina, } \beta \text {-sitosterol, } \\
\beta \text {-daucosterol }\end{array}$ & $\begin{array}{l}\text { Cascas } \\
\text { raízes }\end{array}$ & $\begin{array}{l}\text { FAXING e cols., } \\
1998\end{array}$ \\
\hline S. jambos & Ácido oleanólico & Folhas & $\begin{array}{l}\text { BALANEHRU e } \\
\text { cols., } 1992\end{array}$ \\
\hline S. tripinnatum & $\begin{array}{l}\text { Lupenona, lupeol, } \\
\text { palmitato de lupenila, } \\
\text { obtusalina, } \beta \text {-sitosterol }\end{array}$ & Folhas & $\begin{array}{l}\text { TSAI e cols., } \\
1994\end{array}$ \\
\hline
\end{tabular}

\subsection{Aspectos biológicos}

\subsubsection{Atividade antioxidante}

Atualmente, há acentuada tendência de relacionar-se o desenvolvimento ou desencadeamento de diversas enfermidades, tais como, câncer, diabetes, acidentes vasculares e mesmo o envelhecimento, com a presença principalmente de espécies reativas de oxigênio. 
Radicais livres são conceituados como espécies químicas com um ou mais elétrons não pareados, ocupando orbitais atômicos ou moleculares, e capazes de existir independentemente. Geralmente essas espécies têm meia vida curta, da ordem de minutos a nanossegundos. O elétron livre pode ser centrado em um átomo de oxigênio, nitrogênio, carbono ou enxofre (ABDALLA, 1996).

O termo antioxidante tem sido definido como composto que atua nos sistemas biológicos contra os efeitos potencialmente danosos de processos ou reações oxidativas de macromoléculas ou estruturas celulares. 0 sistema de defesa primário do organismo é formado por substâncias que impedem a formação de espécies reativas ou seqüestram-nas, atuando assim, na etapa de iniciação da cadeia radicalar. O sistema de defesa secundário é constituído por compostos que bloqueiam a etapa de propagação da cadeia radicalar. Neste grupo encontram-se os fenólicos, flavonóides, alfa-tocoferol e tocotrienóis, entre outros. O sistema de defesa terciário inclui os sistemas de reparo do DNA (ABDALLA, 1996).

O estudo de substâncias antioxidantes sofreu grande avanço na busca de compostos aplicados na indústria alimentícia, na prevenção da oxidação lipídica. Algumas espécies vegetais, empregadas como condimentos e especiarias, ricas em terpenos e fenólicos (Rosmaninus officinalis, Salvia officinalis) têm sido estudadas com esta finalidade (GUTTERIDGE e HALLIWELL, 1994; LARSON, 1997).

O fenômeno da lipoperoxidação é uma sucessão em cadeia de eventos bioquímicos que resulta da ação dos radicais livres sobre os lipideos insaturados das membranas celulares gerando algumas substâncias que podem destruir sua estrutura, alterar os mecanismos de troca de metabólitos podendo levar, inclusive, à morte celular. A lipoperoxidação pode ser utilizada como um indicativo do estresse oxidativo celular. Os principais métodos utilizados para a avaliação da lipoperoxidação em 
sistemas biológicos medem a formação de produtos gerados durante as diferentes fases deste processo (LIMA e ABDALLA, 2001).

A avaliação da atividade antioxidante tem sido efetuada avaliando-se a lipoperoxidação através da determinação da velocidade de formação do malonildialdeído como um produto secundário durante a oxidação de ácidos graxos poliinsaturados. Esta técnica é uma avaliação in vitro que determina colorimetricamente o produto de reação entre o ácido tiobarbitúrico e o malonildialdeído formado durante a cisão beta de lipídeos peroxidados. Também pode ser medida no homogenato de cérebro de ratos (STOCKS e colaboradores, 1974).

O crescente interesse no estudo de substâncias com atividade antioxidante e a presença de compostos fenólicos em espécies de Myrtaceae motivou a realização deste ensaio com a finalidade de se detectar a presença de eventuais substâncias com atividade antioxidante que, diminuindo o processo de lipoperoxidação, poderiam ser utilizadas farmacologicamente.

A inibição da formação de malonildialdeído (MDA) em plasma sangüíneo de cavalos foi determinada em extratos de botões florais de Syzygium aromaticum Merr. e Perry (cravo-da-índia) e de folhas de Eucalyptus polyanthemos Schauer, ambas as espécies pertencentes à familia mirtácea. A inibição provocada pelos extratos e pelos compostos eugenol, timol e álcool benzílico foi comparada à inibição provocada pelo butilhidroxitolueno (BHT) e a-tocoferol, dois antioxidantes conhecidos (LEE e SHIBAMOTO, 2001).

\subsubsection{Atividade antimicrobiana}

Rios e colaboradores (1988) classificam as técnicas biológicas de triagem de estudo antimicrobiano de extratos vegetais em técnicas de difusão, de diluição e bioautografia. 
Na técnica de difusão, as substâncias ou extratos vegetais são colocados em contato com o meio de cultura sólido inoculado com microrganismos diversos (bactérias, fungos ou leveduras). Nesta técnica, a amostra não requer diluições em água, possibilitando o emprego de substâncias ou extratos de baixa polaridade.

A técnica de diluição requer dispersão homogênea das amostras a serem ensaiadas em água. Assim, agentes dispersores como polissorbatos podem ser necessários. Após a incubação, o parâmetro empregado na determinação da atividade da amostra é a turbidez do meio líquido, que representa o desenvolvimento ou não de microrganismos.

$\mathrm{Na}$ técnica de bioautografia, os extratos vegetais são submetidos à cromatografia em camada delgada e o cromatograma é nebulizado com meio inoculado de microrganismos. As regiões de inibição de crescimento são analisadas.

Rios e colaboradores (1988) ressaltam a influência de diversos fatores nos resultados, tais como, método de extração, concentração do inóculo, condições de incubação, não recomendando um método em particular.

Rana e Joshi (1992) verificaram a promissora atividade antivirus dos extratos etanólicos de quatro espécies de Syzygium: $S$. megacarpum, $S$. amottianum, S. lanceolatum e S. mangifolia.

Ndounga e colaboradores (1994) testaram as propriedades antibacterianas de folhas e cascas de duas espécies de Syzygium: $S$. brazzvillense e $S$. guineense. Os extratos foram avaliados pela capacidade de formação de halo de inibição e da determinação da concentração inibitória mínima (CIM). A concentração inibitória mínima variou de $62,5 \mu \mathrm{g} / \mathrm{mLL}$ a $4000 \mu \mathrm{g} / \mathrm{mL}$. 


\subsection{Espécie Syzygium cumini (L.) Skeels}

\subsubsection{Distribuição geográfica e descrição geral}

Syzygium cumini é uma árvore exótica, originária da Índia, vastamente difundida pelo cultivo, através de muitas regiões quentes do mundo. É uma árvore grande, glabra, de oito a doze metros de altura, de copa ampla e muito ramificada, com ramos e folhas simples, lisas e dispostas aos pares. As flores são cremes ou brancas, com pétalas arredondadas, caracteristicamente em forma de capuz. O fruto é ovóide, pequeno, de coloração roxa-avermelhada a quase negra, quando maduro. Uma semente única e grande, quando comparada ao tamanho total do fruto é envolta por polpa carnosa (LEGRAND e KLEIN, 1978; OLIVEIRA e SAITO, 1987/1989; COIMBRA, 1994).

Os frutos do jambolão, apesar de um pouco adstringentes, são agradáveis ao paladar. Porém, perto do sabor tão especial das outras tantas mirtáceas brasileiras, como jabuticaba, pitanga, gabiroba, araçá, goiaba e tantas outras, o sabor do jambolão não se destaca tanto (COIMBRA, 1994). Os

frutos do jambolão possuem uma certa semelhança de formato, tamanho e cor com a azeitona. Por esse motivo, "azeitona" passou a ser um nome freqüentemente utilizado para designar o fruto do jambolão, em especial no nordeste brasileiro (JOLY, 1987).

Multiplica-se por sementes, desenvolve-se bem em qualquer tipo de solo, porém permeáveis e profundos. Prefere climas quentes e úmidos, principalmente de regiões litorâneas. Floresce de dezembro até abril e frutifica de janeiro a maio no Brasil (LEGRAND e KLEIN, 1978; OLIVEIRA e SAITO, 1987/1989; COIMBRA, 1994). 


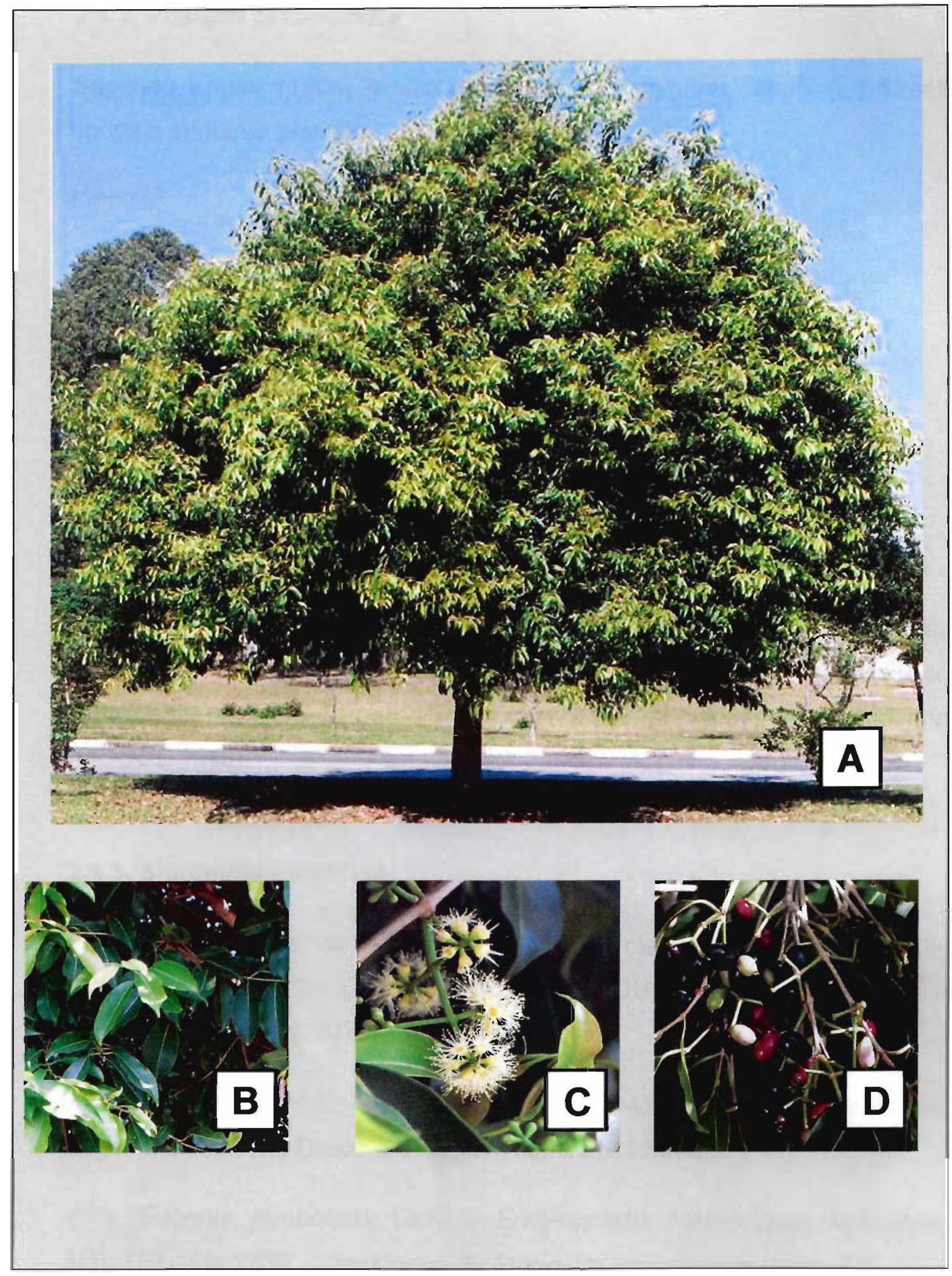

Figura 3 - Syzygium cumini (L.) Skeels. A. Hábito. B. Detalhe do ramo. C. Detalhe do ramo florido. D. Detalhe do ramo frutificado. 


\subsubsection{Posição taxonômica}

Segundo Engler (1964) e Cronquist (1988), Syzygium cumini (L.) Skeels ocupa a seguinte posição taxonômica:

Familia: Myrtaceae

Subfamilia: $\quad$ Myrtoideae

Tribo: $\quad$ Myrteae

Subtribo: $\quad$ Eugeniinae

Gênero: $\quad$ Syzygium

Espécie: $\quad$ Syzygium cumini (L.) Skeels (SKEELS, 1912)

O nome genérico Syzygium ("syzygos") significa par, em grego, e faz referência aos ramos e folhas dispostos aos pares. O epíteto específico cumini está relacionado com plantas aromáticas, principalmente o cominho (PENNA, 1946).

\subsubsection{Sinonímia científica}

Foram encontrados os seguintes sinônimos científicos para a espécie estudada (HOOKER e JACKSON, 1895; MISSOURI Botanical Garden w ${ }^{3}-$ tropics, 2002; USDA, ARS, 2002):

$\checkmark \quad$ Myrtus cumini L. - Species Plantarum 1: 471. 1753. - basiônimo de Eugenia cumini (L.) Druce e Syzygium cumini (L.) Skeels.

$\checkmark$ Eugenia jambolana Lam. - Encyclopédie Méthodique, Botanique 3(1): 198-199. 1789. - basiônimo de Syzygium jambolanum (Lam.) DC. 
$\checkmark \quad$ Calyptranthes caryophyllifolia Willdenow in Usteri - Annotation 17:22.1796. (= Eugenia jambolana).

$\checkmark$ Calyptranthes jambolana Willdenow in Usteri - Annotation 17:23.1796.

$\checkmark \quad$ Syzygium jambolanum (Lam.) DC. - Prodomus Systematis Naturalis Regni Vegetabilis 3: 259. 1828.

$\checkmark$ Eugenia cumini (L.) Druce - Report. Botanical Exchange Club. London. 3: 418.1914.

$\checkmark \quad$ Calyptranthes oneillii Lundell - Bulletin of the Torrey Botanical Club 64(8): 554. 1937.

$\checkmark \quad$ Calyptranthes jambolifera Stokes - A Botanical Materia Medica 3:68. sem data. (= Eugenia jambolana).

\subsubsection{Sinonímia vulgar}

Esta espécie vegetal, por sua ampla distribuição no território brasileiro, recebe inúmeras denominações populares. $\dot{E}$ conhecida popularmente pelos seguintes nomes:

$\checkmark \quad$ Jambolão (LEGRAND e KLEIN 1978; INVENTÁRIO de plantas medicinais do estado da Bahia, 1979; CORREA, 1984; JOLY, 1987; SCHAPOVAL e colaboradores, 1988; ALMEIDA, 1993; SILVA e MILANEZE, 2001).

$\checkmark$ Jamelão (LEGRAND e KLEIN, 1978; INVENTÁRIO de plantas medicinais do estado da Bahia, 1979; CORREA, 1984; ALMEIDA, 1993; SILVA e MILANEZE, 2001). 
$\checkmark \quad$ Jambeiro (INVENTÁRIO de plantas medicinais do estado da Bahia, 1979).

$\checkmark \quad$ Jamboleiro (INVENTÁRIO de plantas medicinais do estado da Bahia, 1979).

$\checkmark \quad$ Jambo-da-Índia (INVENTÁRIO de plantas medicinais do estado da Bahia, 1979).

$\checkmark$ Jalão (LEGRAND e KLEIN, 1978; INVENTÁRIO de plantas medicinais do estado da Bahia, 1979 INVENTÁRIO de plantas medicinais do estado da Bahia, 1979; CORREA, 1984).

$\checkmark \quad$ Jambol (INVENTÁRIO de plantas medicinais do estado da Bahia, 1979; ALMEIDA, 1993).

$\checkmark \quad$ Jambul (INVENTÁRIO de plantas medicinais do estado da Bahia, 1979; ALMEIDA, 1993).

$\checkmark \quad$ Azeitona (INVENTÁRIO de plantas medicinais do estado da Bahia, 1979 INVENTÁRIO de plantas medicinais do estado da Bahia, 1979; JOLY, 1987).

$\checkmark \quad$ Azeitona-doce (INVENTÁRIO de plantas medicinais do estado da Bahia, 1979).

\subsubsection{Aspectos químicos}

Os constituintes químicos identificados nos diversos órgãos de Syzygium cumini (L.) Skeels são apresentados na tabela 4. 
Tabela 4 - Substâncias químicas identificadas em Syzygium cumini (L.) Skeels (Myrtaceae).

\begin{tabular}{|c|c|c|}
\hline Substâncias & Órgão vegetal & Referências bibliográficas \\
\hline Ácido 3,3’-di-O-metil-elágico & $\begin{array}{l}\text { Cascas, folhas e } \\
\text { sementes }\end{array}$ & $\begin{array}{l}\text { PDR, 2000; MAHMOUD e } \\
\text { cols.. 2001 }\end{array}$ \\
\hline Ácido betulínico & Cascas e sementes & $\begin{array}{l}\text { GUPTA e SHARMA, 1974; } \\
\text { PDR, } 2000\end{array}$ \\
\hline Ácido cítrico & Sementes & BHATIA e BAJAJ, 1975 \\
\hline Ácido clorogênico & Folhas & MAHMOUD e cols., 2001 \\
\hline Ácido cratególico & Sementes & GUPTA e SHARMA. 1974 \\
\hline Ácido elágico & $\begin{array}{l}\text { Cascas, folhas e } \\
\text { sementes }\end{array}$ & $\begin{array}{l}\text { BHATIA, SHARMA e } \\
\text { BAJAJ, 1975; PDR, 2000; } \\
\text { MAHMOUD e cols., } 2001\end{array}$ \\
\hline Ácido elosteárico & Sementes & DAS, 1995 \\
\hline Ácido estercúlico & Sementes & PDR, 2000 \\
\hline Ácido gálico & $\begin{array}{l}\text { Cascas, folhas e } \\
\text { sementes }\end{array}$ & $\begin{array}{l}\text { BHATIA, SHARMA e } \\
\text { BAJAJ, 1975; PDR, 2000; } \\
\text { MAHMOUD e cols., } 2001\end{array}$ \\
\hline Ácido glicóico & Sementes & BHATIA e BAJAJ, 1975 \\
\hline Ácido hexaidroxidifênico & Sementes & BHATIA e BAJAJ, 1975 \\
\hline Ácido linoléico & Sementes & SAEED, 1987; PDR, 2000 \\
\hline Ácido malvático & Sementes & PDR, 2000 \\
\hline Ácido mirístico & Sementes & PDR, 2000 \\
\hline \multirow[t]{2}{*}{ Ácido oleanólico } & Flor & $\begin{array}{l}\text { RAJASEKARAN e cols., } \\
1988\end{array}$ \\
\hline & Sementes & $\begin{array}{l}\text { RAJASEKARAN e cols., } \\
1988\end{array}$ \\
\hline Ácido oléico & Sementes & SAEED, 1987; PDR, 2000 \\
\hline
\end{tabular}


Tabela 4 - Substâncias quimicas identificadas em Syzygium cumini (L.) Skeels (Myrtaceae). Continuação.

\begin{tabular}{|c|c|c|}
\hline Substâncias & Órgão vegetal & Referências bibliográficas \\
\hline Ácido oxálico & Sementes & BHATIA e BAJAJ. 1975 \\
\hline Ácido palmítico & Sementes & SAEED, 1987; PDR, 2000 \\
\hline Ácido vernólico & Sementes & PDR, 2000 \\
\hline $\begin{array}{l}\text { Álcoois alifáticos: } \\
\text { Mistura de n-álcoois (C26-C34), } \\
\text { n-octacosanol. n-triacontanol e } \\
\text { dotriacontanol }\end{array}$ & Sementes & GUPTA e SHARMA, 1974 \\
\hline Astragalina & Cascas & PDR, 2000 \\
\hline Canferol & Cascas e folhas & $\begin{array}{l}\text { PDR, 2000; MAHMOUD e } \\
\text { cols., } 2001\end{array}$ \\
\hline Casuarina-6- $\alpha$-D-glicosídeo & Frutos e Sementes & WORMALD e cols., 1996 \\
\hline Corilagina & Sementes & PDR, 2000 \\
\hline Eugenina & Cascas & PDR, 2000 \\
\hline $\begin{array}{l}\text { Friedelina, friedelan-3- } \alpha \text {-ol e epi- } \\
\text { friedelanol }\end{array}$ & Cascas & PDR, 2000 \\
\hline Frutose & Sementes & BHATIA e BAJAJ, 1975 \\
\hline Galoil-glicose & Sementes & PDR, 2000 \\
\hline Hexaidroxidifenoil-glicose & Sementes & BHATIA e BAJAJ, 1975 \\
\hline Isolamentina-3-O-rutinosídeo & Sementes & $\begin{array}{l}\text { VAISHNAVA e GUPTA, } \\
1990\end{array}$ \\
\hline Metil-xantoxilina & Flor & LINDE, 1983 \\
\hline Miricetina e derivados & Folhas & $\begin{array}{l}\text { MAHMOUD e cols., } 2001 ; \\
\text { TIMBOLA e cols., } 2002\end{array}$ \\
\hline
\end{tabular}


Tabela 4 - Substâncias quimicas identificadas em Syzygium cumini (L.) Skeels (Myrtaceae). Continuação.

\begin{tabular}{|c|c|c|}
\hline Substâncias & Órgão vegetal & Referências bibliográficas \\
\hline Miricetina & $\begin{array}{l}\text { Raiz, cascas e } \\
\text { folhas }\end{array}$ & $\begin{array}{l}\text { VAISHNAVA e cols., 1992; } \\
\text { PDR, 2000; MAHMOUD e } \\
\text { cols., } 2001\end{array}$ \\
\hline Miricitrina & Folhas & MAHMOUD e cols.. 2001 \\
\hline Nilocitina & Folhas & MAHMOUD e cols., 2001 \\
\hline $\begin{array}{l}n \text {-parafina: } \\
\text { mistura de } n \text {-alcanos (C26-C34), } \\
n \text {-heptacosano, } n \text {-nonacosano, } n \\
\text {-triacontano e } n \text {-hentriacontano }\end{array}$ & Sementes & GUPTA e SHARMA, 1974 \\
\hline Óleo volátil & Cascas & CRAVEIRO e cols.. 1983 \\
\hline $\begin{array}{l}\text { Óleo volátil: }(E) \text {-cimeno, } \alpha- \\
\text { pineno, } \beta \text {-pineno e mirceno }\end{array}$ & Folhas & LUSTOSA e cols., 1999 \\
\hline $\begin{array}{l}\text { Óleo volátil: trans-olimeno, } \beta \text { - } \\
\text { mirceno. } \alpha \text {-terpineol, acetato de } \\
\text { diidrocarvilil, butirato de geranil e } \\
\text { valerato de terpinil }\end{array}$ & Frutos & $\begin{array}{l}\text { VIJAYAMAND, RAO e } \\
\text { NARASHIMHAM, } 2001\end{array}$ \\
\hline Quercetina & Cascas & PDR, 2000 \\
\hline Quercitrina & Folhas & MAHMOUD e cols., 2001 \\
\hline Sitosterol & Cascas e sementes & $\begin{array}{l}\text { GUPTA e AGRAWAL, } \\
\text { 1970; GUPTA e SHARMA, } \\
\text { 1974; PDR, } 2000\end{array}$ \\
\hline
\end{tabular}




\subsubsection{Aspectos biológicos}

Às folhas de $S$. cumini têm-se atribuído propriedades estrogênicas (RAY, 1967; SANWAL, 1973).

Rajasekaran e colaboradores (1988) avaliaram a atividade anticoncepcional de ácido oleanólico, isolado de suas flores, em ratos albinos. Após 60 dias, verificaram a interrupção na espermatogênese, sem alterações às células espermatogênicas e órgãos reprodutivos.

O extrato clorofórmico de sementes, administrado a ratos, apresentou atividade antiinflamatória nos estágios exsudativos, proliferativos e crônicos da inflamação, além de atividade antipirética (CHAUDHURI, 1990).

Muruganandan e colaboradores (2001), administrando em ratos, o extrato hidroetanólico das cascas de jambolão, relataram atividade antiinflamatória comparável ao ácido acetilsalicílico nos modelos de inflamação seguintes: indução por carragenina, caolinin-carragenina, formaldeído e por algodão. Os autores sugerem que essa atividade pode ser atribuída à inibição de mediadores da inflamação, uma vez que, os taninos, um dos constituintes do extrato, tem a propriedade de inibir a biossintese de prostaglandinas. 0 extrato não induziu lesão gástrica em testes ulcerogênicos agudos e crônicos em ratos, apresentando assim, potente atividade antiinflamatória, sem evidenciar efeitos colaterais na mucosa. O mesmo extrato não mostrou toxicidade na dose de $10,125 \mathrm{~g} / \mathrm{kg}$.

O extrato de cascas de jambolão foi alvo de outros ensaios. O extrato metanólico de cascas, na concentração de $0,2 \mathrm{mg} / \mathrm{mL}$, inibiu significativamente proteases. Assim, Kusumoto e colaboradores (1995), sugerem a inclusão de fitoterápicos em associações para o tratamento da AIDS.

Mukherjee e colaboradores (1998), induziram diarréia em ratos, administrando óleo de rícino. O extrato etanólico de cascas de jambolão 
apresentou efeito inibitório significativo da diarréia. Os autores sugerem que o ácido tânico e os taninos presentes no extrato aumentaram a resistência da mucosa intestinal e reduziram as secreções; redução da motilidade gastrintestinal foi observada.

Segundo Chakraborty e colaboradores (1986), o extrato clorofórmico de sementes, administrado a ratos, apresentou potente atividade depressora do sistema nervoso central, semelhante à dos fármacos psicofarmacológicos.

De Lima e colaboradores (1998) relataram baixa toxicidade aguda (1 $/ \mathrm{g} / \mathrm{kg}<$ DL50< $2 \mathrm{~g} / \mathrm{kg}$ ) do extrato hidroalcoólico de sementes. O extrato hidroalcoólico de folhas apresentou valores comparativamente maiores (DL50 > 3g/kg). Os mesmos autores verificaram, no mesmo estudo, que a administração oral do extrato hidroalcoólico (0,5 e 1,0 g/ $\mathrm{kg}$ ) mostrou atividade contra convulsões induzidas por pentilenotetrazol e por eletrochoque, além de promoverem efeito hipotérmico.

A atividade antimicrobiana do óleo volátil e de extratos de S. cumini tem sido estudada há algumas décadas. O óleo volátil apresentou atividade em relação aos seguintes microrganismos: Staphylococcus aureus, Escherichia coli, Salmonella typhi, Vibrio comma, Klebsiella aerogenes (NARASIMHA e colaboradores, 1970). DE LA CRUZ e FRANCO (1986) observaram que a fração flavonoídica do extrato hidroalcoólico de suas folhas apresentou atividade antimicrobiana em relação a bactérias gram-positivas e gramnegativas. Os extratos aquosos, etanólico, butanólico, acetato de etila de folhas e o óleo essencial de S. cumini foram avaliados por Schapoval e colaboradores (1988) pelo método de cilindros em placa na presença de Escherichia coli e Staphylococcus aureus. Os extratos testados mostraramse ativos frente ao Staphylococcus aureus, sendo que o óleo essencial e o extrato butanólico mostraram leve atividade em relação a Escherichia coli. Lustosa e colaboradores (1999) aplicaramı o óleo volátil de suas folhas em papel de filtro, depositando em meio de cultura sólido. $O$ óleo volátil 
apresentou forte atividade contra Escherichia coli, Staphylococcus aureus, e mostrou-se inativo contra Pseudomonas aeruginosa.

A atividade farmacológica mais estudada para o jambolão é a hipoglicemiante. Folhas, frutos, cascas e, notadamente as sementes são os órgãos mais empregados nesses estudos. Os pós e os extratos fluidos das sementes e dos frutos, ensaiados em cães, ratos e coelhos apresentaram atividade hipoglicemiante (Laboratório Laroche, 1967; RATSIMAMANGA e colaboradores, 1972; OLIVEIRA e SAITO, 1987/1989).

Os trabalhos de Ratsimamanga e colaboradores (1972) revelaram a importância do extrato de $S$. cumini como hipoglicemiante. Os autores sugerem que o extrato estimularia as células beta do pâncreas, embora não tivessem conhecimento quais seriam as substâncias responsáveis pela atividade.

O extrato etanólico das cascas reduziram em $21 \%$ o nível de açúcar no sangue de coelhos hiperglicêmicos, após uma hora da sua administração oral (RATSIMAMANGA e colaboradores, 1973).

Achrekar e colaboradores (1991) descrevem atividade hipoglicemiante do extrato de polpa de fruto de jambolão após 30 minutos da administração a ratos com diabetes induzida por estreptozotocina. O extrato de sementes apresentou efeito semelhante após 24 horas. O extrato da polpa estimulou a secreção de insulina e inibiu a atividade da insulinase. Posteriormente, Kelkar e Kaklij (1997) identificaram um peptideoglicano e um oligossacárido em extratos de polpas de frutos de jambolão. Os autores relatam a resistência do peptideoglicano à degradação por enzimas proteolíticas, o que pode sugerir sua eficácia na administração oral.

O extrato aquoso das sementes (2,5; 5,0 e 7,5 mg/kg), admiristrado por 6 semanas, via oral apresentou atividade hipoglicemiante e antioxidante. A 
atividade hipoglicemiante mostrou-se evidente na dose de $5,0 \mathrm{mg} / \mathrm{kg}$ (GROVER, 200 ).

Damasceno e colaboradores (2002) relataram que a administração, via endovenosa, da solução $1 \%$ da sapogenina extraída de sementes de jambolão, não controlou a glicemia e a poliúria, tampouco diminuiu o consumo de água e ração dos ratos com diabete induzida por estreptozotocina.

Kar e colaboradores (2003), avaliaram a atividade hipoglicêmica de 30 plantas medicinais, em ratos com diabetes induzida por aloxano, na dose úrica de $250 \mathrm{mg} / \mathrm{kg}$. O extrato etanólico liofilizado de sementes de $\mathrm{S}$. cumini foi incluido no estudo e mostrou-se o segundo extrato mais ativo.

O extrato aquoso de sementes de jambolão $(2,5 ; 5,0$ e $7,5 \mathrm{mg} / \mathrm{kg})$ foi administrado, por via oral, durante 6 semanas, a ratos com diabetes induzida por aloxano. Os autores (STANELY e col., 2003) verificaram redução de lipídeos peroxidados, aumento de catalase e superóxido dismutase no cérebro dos ratos. A administração do extrato alcoólico (25, 50 e $100 \mathrm{mg} / \mathrm{kg}$ ) apresentou meihores resultados que o extrato aquoso (5 $\mathrm{g} / \mathrm{kg}$ ), sendo ambos mais efetivos que a glibenclamida (600 $\mu \mathrm{g} / \mathrm{kg})$. $\mathrm{O}$ estudo concluiu que o extrato de sementes de $S$. cumini reduziu o dano tecidual no cérebro de ratos diabéticos.

Sharma e colaboradores (2003) avaliaram a atividade hipoglicêmica e hipolipidêmica do extrato etanólico das sementes de jambolão, administrada por via oral, em coelhos com diabete induzida por aloxano. $O$ extrato $(100 \mathrm{mg} / \mathrm{kg})$ mostrou redução significativa de glicose e dos níveis de hemoglobina glicosilada no plasma, nos diabetes de tipo 1 e 2 . Concomitantemente, observou-se aumento dos níveis de insulina $e$ glicogênio no fígado e nos músculos. A atividade hipolipidêrnica foi caracterizada pela redução de HDL-C, LDL-c e de colesterol total no soro. A atividade da HMG-Coa redutase, enzima que participa na biossintese do 
colesterol, mostrou nivel reduzido. Os autores comentaram a reversão das anormalidades histopatológicas no fígado, pâncreas e na aorta dos animais diabéticos.

Chás preparados com folhas e com sementes de $S$. cumini, em concentrações variando de 2 a $64 \mathrm{~g} / \mathrm{L}$, foram administrados, em substituição à água, durante até 95 dias, a ratos normais e a ratos com diabetes induzida por streptozotocina. Não foi observado efeito hipoglicêmico (TEIXEIRA e col, 1997).

Chás preparados com as folhas de jambolão $(0,25 ; 0,5$ e $1,0 \mathrm{~g} / \mathrm{mL})$, não apresentaram efeito hipoglicemiante em 30 voluntários não diabéticos, de 18 a 26 anos, submetidos ao teste de tolerância à glicose (TEIXEIRA e col, 2000).

Pepato e colaboradores (2001), administraram decocto, preparado com folhas de jambolão $(15 \% \mathrm{~m} / \mathrm{v})$, a ratos com diabetes induzida por streptozotocina, durante 17 dias. Os autores não verificaram alteração significativa em parâmetros normalmente afetados pelo diabetes: niveis de colesterol, HDL, triglicérides, metabolismo de proteínas e enzima conversora de angiotensina. Embora não tenha sido observada atividade hipoglicemiante neste estudo, os autores não excluem a possibilidade de atividade do decocto de folhas de jambolão para o diabetes tipo 2 . 


\section{OBJETIVO}

O objetivo desta dissertação é caracterizar, sob o ponto de vista farmacobotânico, químico e toxicológico, tanto a droga vegetal quanto o extrato hidroetanólico preparado com folhas de Syzygium cumini (L.) Skeels. Para atingir tal objetivo, as seguintes etapas foram desenvolvidas:

- caracterização macroscópica e microscópica da droga constituída de folhas;

- caracterização dos principais grupos de metabólitos secundários presentes na droga e no extrato hidroetanólico;

- determinação do perfil cromatográfico e avaliação do teor de flavonóides, saponinas e taninos do extrato hidroetanólico;

- avaliação do teor, identificação dos componentes e determinação do perfil cromatográfico do óleo volátil;

- avaliação das atividades antioxidante e antimicrobiana do extrato hidroetanólico;

- avaliação da toxicidade aguda do extrato hidroetanólico.

\section{MATERIAIS E MÉTODOS}

\subsection{Material vegetal}

As folhas de Syzygium cumini (L.) Skeels foram coletadas em janeiro de 2000, no campus da Universidade de São Paulo no município de São Paulo (SP). O dia estava ensolarado e a coleta ocorreu no período matutino. $O$ material coletado foi separado em três grupos: o primeiro para o preparo da exsicata; o segundo para o estudo farmacobotânico e o terceiro para a obtenção do pó empregado para o preparo do extrato hidroetanólico.

A espécie foi identificada pela $\mathrm{Dr}^{\mathrm{a}}$ Maria Lúcia Kawasaki, pesquisadora do Instituto de Botânica de São Paulo e depositada no herbário do referido Instituto, onde recebeu o número SP 356475. 


\subsection{Obtenção da droga vegetal (DV)}

As folhas submetidas ao processo de coleta e secagem (BRASIL, 2000) à temperatura ambiente, em local arejado, por 15 dias forneceram a droga vegetal (DV).

\subsection{Estudo farmacobotânico}

No estudo da morfologia da droga constituída de folhas, foi utilizada amostra de sete unidades, de acordo com método descrito por Dibbern e colaboradores (1987). Os caracteres analisados foram: filotaxia; limbo (comprimento x largura); forma (geral, ápice, base e margem); nervação (padrão geral, superfície das nervuras); tipo de indumento; e peciolo (comprimento $\mathrm{x}$ largura). A terminologia empregada na descrição das formas foliares, tipos de indumento e padrões de venação seguiu a . sugerida por Hickey (1979) e Oliveira e Akisue (2000). A terminologia empregada na descrição do pecíolo seguiu a sugerida por Howard (1979). A caracterização macroscópica foi efetuada à vista desarmada e com auxílio de lupa esteroscópica Wild Heerbrugg ${ }^{\circledR}$. As mensurações foram feitas utilizando como instrumento de medida uma régua. Foram avaliadas as características organolépticas de cor, odor, sabor e textura.

A caracterização anatômica das folhas foi realizada em cortes preparados com material fresco, em material conservado em etanol $70 \%$ (VN) (BERLYN e MIKSCHE, 1976) e na droga vegetal. Cortes transversais e longitudinais tangenciais das folhas foram efetuados à mão livre, com o auxilio de lâmina de barbear e suporte de medula do pecíolo da folha de embaúba (Cecropia sp.). Os cortes das folhas foram efetuados ao nível do terço mediano inferior da lâmina foliar plenamente desenvolvida. Cortes transversais do peciolo foram efetuados em micrótomo Spencer $\otimes$ modelo 820 após emblocamento em parafina (OLIVEIRA e AKISUE, 2000). Os 
cortes do peciolo foram efetuados na porção proximal, mediana e distal à lâmina foliar.

Inicialmente, os cortes histológicos foram diafanizados com solução de hipoclorito de sódio a 50\% (VN). Após lavagem com água destilada foram tratados com ácido acético a 1\% (VN), sendo depois tratados com corantes e reativos adequados para cada tipo de estrutura. Nos testes histoquímicos foram empregados floroglucina cloridrica, safranina e fucsina básica para lignina (BUKATSCH, 1972); hematoxilina de Delafield e azul de Astra para celulose (ROESER, 1962); Sudam III (SASS, 1951) para cutina, suberina e lipídeos; cloreto férrico $2 \%$ (JOHANSEN, 1940) para compostos fenólicos; e de Lugol (BERLYN e MIKSCHE, 1976) para amido.

$\mathrm{Na}$ obtenção das preparações semipermanentes, os cortes foram corados com soluções de fucsina básica e azul de Astra (ROESER, 1962) ou azul de Astra e safranina (BUKATSCH, 1972) e montados, entre lâmina e lamínula, em glicerol-água (1:1) (OLIVEIRA e AKISUE, 2000).

A nomenclatura empregada para as descrições anatômicas é baseada em Metcalfe e Chalk(1950), Howard (1979) e Oliveira e Akisue (2000).

Os cortes foram observados com auxilio de microscópio Olympus ${ }^{\circledR}$ e as fotos foram obtidas com auxilio de fotomicroscópio Nikon ${ }^{\circledR}$

\subsection{Preparo do extrato hidroetanólico liofilizado (EHEL)}

A droga vegetal (DV) foi pulverizada em moinho de facas e martelos de marca Thomas ${ }^{\circledR}$ obtendo-se um pó que foi submetido ao tamis $n^{0} 16$ (FARMACOPÉIA Brasileira 4.ed., 1988).

O extrato hidroetanólico foi preparado pelo processo geral P (percolação). Três quilogramas da droga vegetal pulverizada foram extraídos com o etanol a $70 \%(p / N)$ na proporção de 10 litros para cada quilograma da 
droga vegetal na velocidade de 20 gotas por minuto até a obtenção de cerca de 30 litros de solução (FARMACOPÉlA Brasileira 2.ed., 1959; FARMACOPÉIA Brasileira 4.ed., 1988; PRISTA e colaboradores, 1996).

Esta solução foi concentrada em evaporador rotatório Büchi $^{\circledR}$ a cerca de 45 ${ }^{\circ} \mathrm{C}$ até a evaporação completa de etanol. A seguir, procedeu-se à liofilização em equipamento de marca Edwards ${ }^{\circledR}$. O extrato hidroetanólico liofilizado (EHEL) foi homogeneizado, tamisado à pó fino em tamis com abertura nominal de malha de $180 \mu \mathrm{m}$ e estocado em frasco de vidro âmbar com tampa e mantido em dessecador. O EHEL foi empregado no estudo químico e nos ensaios biológicos.

\subsection{Estudo químico}

\subsubsection{Triagem fitoquímica}

A droga vegetal (DV) e o extrato hidroetanólico liofilizado (EHEL) foram submetidos à triagem fitoquímica visando avaliar a presença dos grupos de metabólitos secundários.

Análise cromatográfica em camada delgada complementou a caracterização dos diversos grupos de substâncias.

\subsubsection{Alcalóides}

Dois gramas da droga e do EHEL foram aquecidos à ebulição com $10 \mathrm{~mL}$ de ácido clorídrico $2 \mathrm{~N}$. Após o resfriamento, filtrou-se através de papel de filtro e o filtrado foi colocado num funil de separação e alcalinizado com hidróxido de amônio $50 \%$ até pH 11. A solução alcalina foi extraída com três porções sucessivas de $10 \mathrm{~mL}$ da mistura éter-clorofórmio (3:1). A fase éter-clorofórmio foi filtrada através de sulfato de sódio anidro e colocada em béquer para a completa evaporação do solvente. O resíduo foi redissolvido com $2 \mathrm{~mL}$ de ácido cloridrico $0,1 \mathrm{~N}$. A solução ácida foi dividida em cinco 
tubos de ensaio. Aos cinco tubos de ensaio de cada fase foram adicionados os seguintes reativos de precipitação: Bertrand, Bouchardat, Dragendorff, Hager e Mayer. A formação de precipitado foi considerada resultado positivo para a presença de alcalóides (MATOS, 1988).

\subsubsection{Antraderivados}

Dois gramas da droga e do EHEL foram submetidos à fervura com 30mL de ácido cloridrico $6 \mathrm{M}$ até obter um precipitado indicativo de hidrólise. Após o resfriamento, filtrou-se através de papel de filtro. A solução ácida foi extraída com duas porções de $5 \mathrm{~mL}$ de éter. A fase etérea foi filtrada através de sulfato de sódio anidro e transferida para um tubo de ensaio com tampa e foi adicionado $2 \mathrm{~mL}$ de hidróxido de amônio $6 \mathrm{~N}$. Após agitação e a separação das fases, a camada aquosa intensamente colorida de vermelho e a etérea incolor indica a presença de antraderivados (MATOS, 1988).

\subsubsection{Cumarinas}

Dois gramas da droga e do EHEL foram lavados com éter de petróleo a frio. Depois de lavado, o pó foi colocado em béquer e extraído com $10 \mathrm{~mL}$ de solução de hidróxido de sódio $0,5 \mathrm{~N}$ a $60^{\circ} \mathrm{C}$. Após o resfriamento, filtrou-se através de papel de filtro. O filtrado foi transferido para um funil de separação e acidificado com ácido cloridrico 1N. Após acidificação, extraiuse com duas porções de $10 \mathrm{~mL}$ de éter etílico. O extrato etéreo foi colocado em cápsula de porcelana e concentrado. A seguir, foi tratado com uma gota de solução saturada de hidroxilamina em álcool e uma gota de solução alcoólica de hidróxido de potássio $0,5 \mathrm{~N}$. A mistura foi aquecida até o início da ebulição e, após o resfriamento, foi adicionada uma gota de ácido cloridrico $0,5 \mathrm{~N}$. Em seguida, adicionou-se uma gota de solução aquosa de cloreto férrico a $1 \%(\mathrm{p} / \mathrm{V})$. O aparecimento de coloração vermelha indica a presença de cumarinas (FARNSWORTH, 1966). 


\subsubsection{Esteróides e triterpenóides}

Dois gramas da droga e do EHEL foram fervidos com $20 \mathrm{~mL}$ de etanol a $80 \%(p / N)$ durante 5 minutos. Após o resfriamento, filtrou-se através de papel de filtro e ao filtrado foi adicionado o reativo de Liebermann-Burchard que utiliza $1 \mathrm{~mL}$ de anidrido acético e três gotas de ácido sulfúrico concentrado. O aparecimento de coloração azul seguida de verde é indicativa da presença de esteróides livres, enquanto que o desenvolvimento de coloração parda até vermelha indica a presença de triterpenóides pentacíclicos livres (MATOS, 1988).

\subsubsection{Flavonóides}

Dois gramas da droga e do EHEL foram fervidos com $20 \mathrm{~mL}$ de etanol a $80 \%(\mathrm{p} / \mathrm{N})$. Após o resfriamento, filtrou-se através de papel de filtro e o filtrado foi separado em três tubos de ensaio para a adição de alguns reativos.

O desenvolvimento ou intensificação de fluorescência em luz ultravioleta após a adição de solução etanólica de cloreto de alumínio $5 \%(\mathrm{p} / \mathrm{V})$, o desenvolvimento de coloração amarela após a adição de solução de hidróxido de sódio $1 \mathrm{~N}$ e o aparecimento de coloração rósea a vermelha após a adição de alguns fragmentos de magnésio metálico com $0,5 \mathrm{~mL}$ de ácido clorídrico concentrado foi considerado indicativo da presença de flavonóides (MATOS, 1988).

\subsubsection{6. Óleo volátil}

Dois gramas da droga e do EHEL foram colocados em uma lâmina contendo um anel metálico coberto com outra lâmina microscópica. $\mathrm{O}$ conjunto foi submetido ao aquecimento. As gotículas do hidrodestilado depositadas na lâmina superior foram analisadas ao microscópio óptico com reagente Sudam III. Também foi efetuada a avaliação do odor aromático da droga e de seu microdestilado. O resultado considerado positivo para a presença de substâncias lipofílicas voláteis foi o 
desenvolvimento de coloração vermelho-alaranjado nas gotículas dispersas no meio aquoso (FARNSWORTH, 1966).

\subsubsection{Saponinas}

Dois gramas da droga e do EHEL foram fervidos com $15 \mathrm{~mL}$ de água destilada durante dois minutos. Após o resfriamento, filtrou-se através de papel de filtro e o filtrado foi colocado em tubo de ensaio e submetido à forte agitação por cerca de um minuto para a avaliação da propriedade afrogênica. A presença de espuma persistente foi considerada resultado positivo para a presença de saponinas (FARNSWORTH, 1966).

\subsection{Determinação do índice de espuma}

Um grama da droga e do EHEL foram exatamente pesados e transferidos para um erlenmeyer contendo $50 \mathrm{~mL}$ de água fervente. A ebulição foi mantida por 30 minutos. Após o resfriamento e filtração, para um balão volumétrico do $100 \mathrm{~mL}$, repetiu-se a extração utilizando-se porções sucessivas de $10 \mathrm{~mL}$ de água fervente até completar o volume de $100 \mathrm{~mL}$. $\mathrm{O}$ extrato obtido foi distribuído em 10 tubos de ensaio, de iguais dimensões e identificados em seqüência numérica, em alíquotas de $1,2,3$, até $10 \mathrm{~mL} e$ ajustado o volume em cada tubo a $10 \mathrm{~mL}$ com água destilada. Os tubos foram tampados e agitados por 15 segundos, com 2 agitações por segundo e deixados em repouso por 15 minutos. O índice de espuma foi calculado observando os tubos em que a altura da espuma foi um centímetro (FARMACOPÉIA Brasileira 4.ed., 2000).

\subsection{7.2. Determinação da atividade hemolítica}

Vinte e cinco miligramas da droga e do EHEL foram exatamente pesados e transferidos para um balão volumétrico de $100 \mathrm{~mL}$. O volume foi completado com tampão fosfato $\mathrm{pH} \mathrm{7,4.} \mathrm{A} \mathrm{solução} \mathrm{obtida} \mathrm{foi} \mathrm{distribuida} \mathrm{em} 4$ tubos de ensaio, de iguais dimensões e identificados em seqüência numérica de 1 
até 4 , em alíquotas de $0,1 \mathrm{~mL}, 0,2 \mathrm{~mL}, 0,5 \mathrm{~mL}$ e $1 \mathrm{~mL}$. Foi ajustado o volume em cada tubo a $1 \mathrm{~mL}$ com tampão fosfato $\mathrm{pH} 7,4$ e adicionado $1 \mathrm{~mL}$ de uma suspensão de sangue a $2 \%$. Os tubos foram tampados, invertidos cuidadosamente para misturar e evitar a formação de espuma e deixados em repouso por 30 minutos. Os tubos foram novamente agitados $e$ deixados em repouso por 6 horas à temperatura ambiente. A atividade hemolítica foi determinada verificando os tubos em que a hemólise total foi observada (FARMACOPÉ|A Brasileira 4.ed., 2000).

\subsubsection{Taninos}

Dois gramas da droga e do EHEL foram fervidos com $20 \mathrm{~mL}$ de água destilada. Após o resfriamento, filtrou-se através de papel de filtro e o filtrado foi separado em cinco tubos de ensaio. A cada um dos tubos foram adicionados solução aquosa de acetato de chumbo $10 \%(\mathrm{p} / \mathrm{V})$, solução aquosa de cloreto férrico $2 \%(\mathrm{p} / \mathrm{V})$, solução aquosa de sulfato de quinina a $0,1 \%(p / V)$ em meio ácido, solução aquosa de gelatina a 2,5\% (p/V) em meio ácido e solução aquosa de acetato de cobre $5 \%(\mathrm{p} / \mathrm{N})$, respectivamente. A formação de precipitado após a adição de cada um dos reativos foi considerada resultado positivo para a presença de taninos (FARNSWORTH, 1966).

\subsubsection{Fracionamento do extrato hidroetanólico liofilizado (EHEL)}

Vinte gramas do EHEL foram dissolvidos em 100mL de etanol 70\% ( $p / N)$ e fracionados empregando-se solventes de polaridade crescente (diclorometano, acetato de etila e $n$-butanol). Os extratos assim obtidos foram concentrados até a secura e denominados, respectivamente de DCM, ACE e n-BUT. O extrato em etanol 70\% (p/) restante no funil de separação foi concentrado até a secura em banho-maria e denominado de ETA. 


\subsubsection{Hidrólise ácida do extrato hidroetanólico liofilizado (EHEL)}

A $3 \mathrm{~g}$ do EHEL foram adicionados $30 \mathrm{~mL}$ de ácido clorídrico $2 \mathrm{M}$ em um erlenmeyer. O conjunto foi aquecido até fervura e mantido em banho-maria à temperatura de $90-100{ }^{\circ} \mathrm{C}$ por 30 minutos. Após o resfriamento em água corrente, o líquido foi filtrado através de papel de filtro. A solução resultante foi denominada de EHEL hidrolisado (HARBONE, 1984).

\subsubsection{Análise cromatográfica em camada delgada (CCD) da droga vegetal (DV) e do extrato hidroetanólico liofilizado (EHEL)}

Foram analisados os perfis cromatográficos da droga vegetal pulverizada (subitem 4.4), do EHEL (subitem 4.4), fração DCM (subitem 4.5), fração ACE (subitem 4.5), fração n-BUT (subitem 4.5), fração ETA (subitem 4.5) e óleo volátil (subitem 4.7.1) em camada delgada para avaliação da presença dos principais grupos de metabólitos secundários (WAGNER e BLADT, 1996).

Utilizaram-se as seguintes fases móveis neste estudo:

- Fase móvel 1 (FM 1): acetato de etila/ ácido acético glacial (90:10)

- Fase móvel 2 (FM 2): n-butanol/ácido acético glacial/água destilada (4:1:5)

- Fase móvel 3 (FM 3): ácido acético a 30\% (100\%)

- Fase móvel 4 (FM 4): clorofórmio/acetonalácido fórmico(75:16,5:8,5)

- Fase móvel 5 (FM 5): tolueno/acetato de etila (93:7)

Os suportes de tamanho $20 \times 20 \mathrm{~cm}$ eram de vidro com aplicação de silicagel $G_{254 n m}$ e celulose na espessura de $250 \mu$. As placas de silicagel $\mathrm{GF}_{254 \mathrm{~nm}}$ foram mantidas em estufa a $105^{\circ} \mathrm{C}$ pelo período mínimo de uma hora. As cubas cromatográficas retangulares foram saturadas completamente com a fase móvel e auxílio de papel de filtro previamente 
durante 24 horas. Os desenvolvimentos foram simples e ascendentes em percursos de 12 e $15 \mathrm{~cm}$.

Os cromatogramas foram observados à luz visivel, luz ultravioleta à $254 \mathrm{~nm}$, luz ultravioleta à $366 \mathrm{~nm}$ e nebulizados com os seguintes reveladores: NP (solução metanólica a $1 \%$ de difenilboriloxietilamina) seguido de PEG (solução etanólica de polietilenoglicol 4000) para a detecção de flavonóides e solução de anisaldeído sulfúrico AS (solução contendo 0,5mL de anisaldeído, $10 \mathrm{~mL}$ de ácido acético glacial, $85 \mathrm{~mL}$ de metanol e $5 \mathrm{~mL}$ de ácido sulfúrico concentrado) e solução de vanilina sulfúrica VS (solução etanólica a $1 \%$ de vanilina seguida de solução etanólica a $10 \%$ de ácido sulfúrico) para a detecção de terpenóides e saponinas. Depois de nebulizadas, as placas foram aquecidas a $105^{\circ} \mathrm{C}$ por 5 a 10 minutos para depois serem observadas à luz visivel, luz ultravioleta à $254 \mathrm{~nm}$ e luz ultravioleta à 366nm (WAGNER e BLADT, 1996).

\subsubsection{Doseamento dos principais metabólitos secundários presentes}

Para as determinações físico-químicas foram empregados quatro tipos de droga vegetal, uma para cada estação do ano e o EHEL. Assim, as variações ocorridas durante o ano poderiam ser observadas.

A droga vegetal coletada em janeiro de 2000 foi denominada DV-verão. Posteriormente, foram coletadas folhas em maio de 2002 (DV-outono), agosto de 2002 (DV-inverno) e novembro de 2002 (DV-primavera), sempre em dias ensolarados e no periodo matutino. As drogas vegetais assim obtidas após secagem foram pulverizadas em moinho de facas e martelos de marca Thomas ${ }^{\circledR}$ obtendo-se um pó que foi submetido ao tamis $n^{\circ} 16$ (FARMACOPÉIA Brasileira 4.ed., 1988). 


\subsubsection{Doseamento de taninos}

A avaliação da quantidade de taninos no pó da droga vegetal, bem como no EHEL foi realizada segundo o método descrito no suplemento da Farmacopéia Européia (2001). As amostras e o padrão devem ser protegidos da luz durante a extração, solubilização e as diluições. O resultado, expresso em porcentagem $(p / p)$ de taninos, é obtido pela reação destes com o ácido fosfomolibdotúngstico, utilizando-se como substância de referência o pirogalol.

\subsection{Preparo das amostras e da solução padrão}

Amostra: a $0,75 \mathrm{~g}$ do pó da droga vegetal e $0,5 \mathrm{~g}$ do EHEL foram adicionados $150 \mathrm{~mL}$ de água destilada em um erlenmeyer. $O$ conjunto foi aquecido até fervura e mantido em banho-maria à temperatura de $80-90^{\circ} \mathrm{C}$ por 30 minutos. Após o resfriamento em água corrente, a mistura foi transferida quantitativamente para um balão volumétrico e completado o volume para $250 \mathrm{~mL}$ com água destilada. Após a decantação dos sólidos, o líquido foi filtrado através de papel de filtro. Foram descartados os primeiros $50 \mathrm{~mL}$ e o restante foi denominado de solução mãe (SM).

Padrão: sob abrigo da luz, $50 \mathrm{mg}$ de substância de referência (pirogalol) foram dissolvidos em $100 \mathrm{~mL}$ de água destilada. Cinco mililitros desta solução foram ailuídos para $100 \mathrm{~mL}$ com água destilada. A reação de coloração foi efetuada utilizando-se $2 \mathrm{~mL}$ desta solução, em menos de 15 minutos depois da dissolução do pirogalol.

\subsection{Polifenóis totais}

Cinco mililitros de SM foram diluidos em um balão volumétrico de $25 \mathrm{~mL}$, com água destilada e denominados de polifenóis totais (PT). Dois mililitros de cada uma das soluções PT foram utilizados na reação de coloração. 


\subsection{Polifenóis não adsorvidos pelo pó-de-pele}

Em $10 \mathrm{~mL}$ de SM foram adicionados $0,1 \mathrm{~g}$ de pó de pele CRS, agitando-se mecanicamente e vigorosamente por 60 minutos, filtrando-se em seguida. Cinco mililitros de cada filtrado foram diluídos a $25 \mathrm{~mL}$ com água destilada e denominados de polifenóis não adsorvidos (PNA). Aliquotas de dois mililitros de cada diluição foram empregadas para o desenvolvimento da reação descrita a seguir.

\subsection{Desenvolvimento da reação}

Em $2 \mathrm{~mL}$ de cada uma das diluiçōes reagentes (padrão, PT e PNA) foi adicionado $1 \mathrm{~mL}$ da solução reagente de ácido fosfomolibdotúngstico, $10 \mathrm{~mL}$ de água destilada e depois completados para $25 \mathrm{~mL}$ com solução de carbonato de cálcio a $29 \%(\mathrm{p} / \mathrm{V})$. Exatamente 30 minutos após a adição do último reagente, mediu-se a absorvância a 760rım, utilizando-se água destilada como branco. As leituras das absorvâncias foram efetuadas em espectofotômetro Beckman® UVNisível modelo DU 70.

\subsubsection{Doseamento de flavonóides}

A avaliação da quantidade de flavonóides no pó da droga vegetal, bem como no EHEL foi realizada segundo o método descrito na quarta edição da Farmacopéia Brasileira (2001). O resultado, expresso em porcentagem $(p / p)$ de flavonóides totais, é obtido pela reação destes com o cloreto de aluminio, calculados como quercetina $\left(\mathrm{C}_{15} \mathrm{H}_{10} \mathrm{O}_{7}\right)$.

\subsection{Preparo das amostras}

Amostra: $0,7 \mathrm{~g}$ do pó da droga vegetal e $0,4 \mathrm{~g}$ do EHEL foram colocados em balão de fundo redondo de $100 \mathrm{~mL}$. Foi acrescentado $1 \mathrm{~mL}$ de uma solução aquosa de hexametilenotetramina a $0,5 \%(\mathrm{p} N), 20 \mathrm{~mL}$ de acetona e $2 \mathrm{~mL}$ de ácido clorídrico. $O$ conjunto foi aquecido e mantido em banho-maria, sob refluxo, por 30 minutos. Após o resfriamento, a mistura foi filtrada em algodão para um balão volumétrico de $100 \mathrm{~mL}$, e o resíduo com o algodão 
foram retornados para o mesmo balão de fundo redondo, adicionado de $20 \mathrm{~mL}$ de acetona. Após 10 minutos de refluxo, o conjunto foi resfriado à temperatura ambiente e filtrado novamente para o balão volumétrico de $100 \mathrm{~mL}$. Esta operação foi repetida mais uma vez e o balão volumétrico foi completado com acetona.

\subsection{Extração com acetato de etila}

Vinte mililitros desta solução foram transferidos para um funil de separação e tratados com $20 \mathrm{~mL}$ de água destilada. Após, foram realizadas 4 extrações com acetato de etila $(15 \mathrm{~mL}, 10 \mathrm{~mL}, 10 \mathrm{~mL}$ e $10 \mathrm{~mL})$. As fases de acetato de etila foram reunidas e lavadas com duas alíquotas de $50 \mathrm{~mL}$ de água destilada, sendo transferidas para um balão volumétrico de $50 \mathrm{~mL}$, completando-se o volume com acetato de etila. Esta solução foi denominada de solução mãe (SM).

\subsection{Desenvolvimento da reação}

Em $10 \mathrm{~mL}$ de cada SM foi adicionado um mililitro da solução reagente de cloreto de alumínio e depois completados para $25 \mathrm{~mL}$ com solução de metanólica de ácido acético a $5 \%$ (VN). O branco foi preparado diluindo-se $10 \mathrm{~mL}$ da SM para $25 \mathrm{~mL}$ em balão volumétrico com solução metanólica de ácido acético a $5 \%(\mathrm{VN})$. Exatamente 30 minutos após a adição do último reagente, mediu-se a absorvância a $425 \mathrm{~nm}$, utilizando-se o branco para o ajuste do zero. As leituras das absorvâncias foram efetuadas em espectofotômetro Beckman® UVNisivel modelo DU 70.

\subsubsection{Doseamento de saponinas}

O doseamento de saponinas foi realizado segundo metodologia descrita por Namba e colaboradores (1974). Dez gramas do pó da droga vegetal e do EHEL foram extraídos em aparelho de Soxhlet com metanol. O extrato 
metanólico foi filtrado e evaporado à secura em evaporador rotatório de marca Büchi ${ }^{\oplus}$. O resíduo foi dissolvido em 100 rrı de água destilada e a solução aquosa foi lavada com três porções de $30 \mathrm{~mL}$ de éter etílico. Em seguida, a solução aquosa foi aquecida em banho-maria até a eliminação do éter etílico. Após resfriamento, a solução aquosa foi extraída com cinco porções de $40 \mathrm{~mL}$ de $n$-butanol saturado com água destilada. O extrato butanólico foi lavado com água destilada e posteriormente concentrado até a secura em evaporador rotatório, em balão previamente tarado. O resíduo foi seco em estufa Fanem ${ }^{\circledR}$ a $80{ }^{\circ} \mathrm{C}$ por duas horas, resfriado e pesado. A operação foi sucessivamente repetida até peso constante. Os teores de saponinas da droga vegetal e do EHEL, representados pela média aritmética de duas determinações, foram expressos em porcentagem ( $p / p)$.

\section{6. Óleo volátil}

\subsubsection{Determinação do teor de óleo volátil}

A coleta de folhas frescas para a extração do óleo volátil foi realizada no periodo da manhã, durante o periodo de floração O óleo volátil foi extraído por destilação por arraste de vapor utilizando-se um aparelho de Clevenger modificado por Wasicky e Akisue (1969) contendo folhas frescas fragmentadas, durante quatro horas (FARMACOPÉIA Brasileira 4.ed., 2000). Foi determinada a porcentagem de óleo em relação ao peso de folhas frescas. O óleo volátil obtido foi empregado na análise cromatográfica em fase gasosa para identificação dos componentes, na determinação do índice de refração e na determinação do perfil cromatográfico.

\subsubsection{Análise do óleo volátil por cromatografia gasosa}

Parte do óleo volátil obtido das folhas frescas foi analisada a fim de se determinar seus constituintes principais. A análise foi efetuada no Instituto Agronômico Campinas. Empregou-se neste estudo, cromatógrafo a gás 
acoplado a espectrômetro de massas com as seguintes condições de análise:

Equipamento:

Coluna capilar:

Injetor:

Detector:

Impacto de elétrons:

Gás de arraste:

Fluxo:

Split:

Programa de temperatura:

Diluição:

Volume de injeção:
Cromatógrafo a gás acoplado a espectrômetro de massas (Shimadzu ${ }^{\circledR}$, QP-5000)

DB-5 $(30 \mathrm{~m} \times 0,25 \mathrm{~mm} \times 0,25 \mu \mathrm{m})$

$240^{\circ} \mathrm{C}$

$230^{\circ} \mathrm{C}$

$70 \mathrm{eV}$

$\mathrm{He}$

$1,0 \mathrm{~mL} / \mathrm{min}$

$1 / 20$

$60{ }^{\circ} \mathrm{C}-240{ }^{\circ} \mathrm{C}, 3{ }^{\circ} \mathrm{C} / \mathrm{min}$

$3 \mathrm{mg}$ de óleo $/ 1 \mathrm{~mL}$ de acetato de etila $1 \mu \mathrm{L}$

A identificação das substâncias foi efetuada através da comparação dos seus espectros de massas com o banco de dados do sistema CG-EM (Nist 62 lib.), literatura (McLAFFERTY e STAUFFER, 1989) e dos indice de retenção (ADAMS, 1995) .

\subsubsection{Determinação do índice de refração}

A determinação do índice de refração foi realizada em refratômetro Schmidt + Haensch $^{\circledast}$ modelo DUR-W2 a $20{ }^{\circ} \mathrm{C}$ calibrando o aparelho com água destilada também a $20^{\circ} \mathrm{C}$ (FARMACOPÉIA Brasileira 4.ed., 1988). 


\section{Ensaios biológicos}

\subsubsection{Toxicidade aguda}

O ensaio de toxicidade aguda foi realizado como uma avaliação preliminar sobre as propriedades tóxicas do EHEL de Syzygium cumini, fornecendo dados sobre eventuais riscos à saúde, resultantes de uma exposição de curta duração pela via de administração oral. Observou-se o efeito produzido em 14 dias, de uma dose única de $5 \mathrm{~g} / \mathrm{Kg}$ em camundongos. A metodologia empregada seguiu a preconizada por Brito (1994).

\subsubsection{Grupo de animais}

Dezoito camundongos Swiss saudáveis, obtidos do Biotério do Conjunto das Químicas da Universidade de São Paulo, foram aclimatados às condições de laboratório durante pelo menos sete dias antes de serem aleatoriamente divididos nos vários grupos de ensaio. As fêmeas eram nulíparas e não-prenhas. Os camundongos foram agrupados em quatro grupos por sexo, assim distribuídos:

Grupo 1: quatro fêmeas que serviram de controle (água destilada).

Grupo 2: quatro fêmeas que serviram de teste (solução teste).

Grupo 3: cinco machos que serviram de controle (água destilada).

Grupo 4: cinco machos que serviram de teste (solução teste).

\subsubsection{Condições do laboratório e alimentação}

A temperatura do laboratório manteve-se entre $22{ }^{\circ} \mathrm{C} \pm 3{ }^{\circ} \mathrm{C}$ e a taxa de umidade relativa do ar esteve situada entre $30 \%$ e $70 \%$. O laboratório forneceu ciclos de 12 horas de períodos de claro e escuro. O regime alimentar adotado foi o clássico, com ração tipo Purina ${ }^{\circledR}$ e água potável ad libitum.

\subsubsection{Dose}

Inicialmente, foi utilizada a dose de $5 \mathrm{~g}$ do EHEL/Kg, que é a dose recomendada por Brito (1994) para substâncias pouco tóxicas. Se esta 
dose não produzir mortalidade nos cinco machos e quatro fêmeas testados, não há necessidade de utilizar três doses suficientemente espaçadas a fim de avaliar os efeitos tóxicos e as diferentes taxas de mortalidade. Foram preparados $10 \mathrm{~mL}$ de uma solução contendo $5 \mathrm{~g}$ do EHEL (subitem 4.4.). A massa média das fêmeas dos grupos (1) e (2) era de cerca de $30 \mathrm{~g}$, então elas receberam uma dose de $0,3 \mathrm{~mL}$ desta solução (correspondendo a $150 \mathrm{mg}$ do EHEL). A massa média dos machos dos grupos (3) e (4) era de cerca de $40 \mathrm{~g}$, fazendo com que eles recebessem uma dose de $0,4 \mathrm{~mL}$ da mesma solução (correspondendo a $200 \mathrm{mg}$ do EHEL). Os camundongos estavam em jejum de doze horas antes da administração da solução por gavagem, e utilizando-se uma cânula apropriada. Após a administração, os animais foram privados de alimentos e água por um periodo de quatro horas.

\subsubsection{Parâmetros observados}

Os animais foram observados aos $30,60,120,240,360$ minutos após a administração e após 24 e 48 horas e, a partir de então, a cada 2 dias durante 14 dias. Durante este período foram monitorados a atividade geral; alteração de pêlos e pele; comportamento; efeitos sobre a locomoção; contorção; tremores; convulsões; respiração; cianose; massa corporal; consumo de água; consumo de ração, número de óbitos e exames macroscópicos dos órgãos.

\subsubsection{Parâmetros macroscópicos}

No $14^{\circ}$ dia, todos os camundongos foram anestesiados e sacrificados. Foi realizada, então, análise de alterações macroscópicas quanto ao tamanho e coloração e pesagem dos seguintes órgãos: coração e pulmões, fígado e rins (BRITO, 1994). 


\subsubsection{Atividade antimicrobiana}

A atividade antimicrobiana do EHEL, através da determinação da concentração inibitória mínima (CIM), foi avaliada pelo método de diluição em meio líquido. Várias concentrações do EHEL foram testadas, em triplicata, para a determinação da CIM. As amostras foram ensaiadas em relação a diferentes microrganismos como bactéria Gram-positiva, bactéria Gram-negativa, bolor e levedura (THE NATIONAL COMMITEE FOR CLINICAL LABORATORY STANDARDS, 2000) .

\subsubsection{Material}

O EHEL em diferentes quantidades foram diluidos em $10 \mathrm{~mL}$ de solução aquosa de dimetilsulfóxido a $50 \%$, originando soluções finais de concentrações de $1000 \mu \mathrm{g} / \mathrm{mL}, 500 \mu \mathrm{g} / \mathrm{mL}$ e $250 \mu \mathrm{g} / \mathrm{mL}$.

Os meios de cultura empregados foram caldo ágar caseína-soja (Difco ${ }^{\circledR}$ ) e caldo caseína-soja (Difco ${ }^{\circledR}$ ) para bactérias e caldo ágar Sabouraud-dextrose $\left(\right.$ Difco $\left.^{\circledR}\right)$ e caldo Sabouraud-dextrose $\left(\right.$ Difco $\left.^{\circledR}\right)$ para o bolor e a levedura.

As seguintes suspensões de microrganismos padrões foram empregadas: Staphylococcus aureus ATCC 6.538, Escherichia coli ATCC 10.536, Candida albicans ATCC 10.231 e Aspergillus niger ATCC 6.404.

O padrão de antibiótico utilizado foi cloranfenicol (Carlo Erba ${ }^{\circledR}$ ) para bactérias e anfotericina $B\left(\right.$ Bristol $^{\circledR}$ ) para o bolor e a levedura.

Foram utilizadas placas de Petri estéreis Interlab ${ }^{\circledR}$ e pipetador automático Finnipette ${ }^{(3)}$ com volume de 100 a $1000 \mu \mathrm{L}$.

\subsubsection{Preparação dos meios de cultura}

Os meios de cultura foram preparados a partir do meio desidratado, conforme instrução do fabricante (Difco ${ }^{\circledR}$ ) e esterilizados em autoclave Luferco ${ }^{\circledR}$ modelo 39.211 a $121^{\circ} \mathrm{C}$, durante 20 minutos. 


\subsubsection{Preparação da solução fisiológica estéril}

A solução fisiológica foi preparada com cloreto de sódio $\left(M^{2}{ }^{\circledR}{ }^{\circledR}\right)$, na concentração de $0,9 \%$ em água destilada, e submetida à esterilização na mesma autoclave a $121^{\circ} \mathrm{C}$, durante 20 minutos.

\subsubsection{Preparação das suspensões de microrganismos}

Todas as espécies bacterianas foram cultivadas em meio inclinado de ágar caseina-soja, incubando-se os tubos em estufa Fanem ${ }^{\circledR}$ modelo 001/ESP a $30{ }^{\circ} \mathrm{C}-35{ }^{\circ} \mathrm{C}$, durante 24 horas. A massa celular resultante do crescimento foi recolhida com $9 \mathrm{~mL}$ de solução fisiológica estéril e a suspensão obtida foi submetida à contagem de microrganismos viáveis, pela técnica de semeadura em profundidade. Uma gota da suspensão obtida foi adicionada em $9 \mathrm{~mL}$ de solução fisiológica estéril e, a partir desta, foram efetuadas diluições decimais seriadas até $10^{-6} \mathrm{em} 9 \mathrm{~mL}$ de solução fisiológica estéril. Alíquotas de $1 \mathrm{~mL}$ das diluições de $10^{-4}, 10^{-5}$ e $10^{-6}$ foram transferidas para placas de Petri Interlab ${ }^{\circledR}$ esterilizadas, em triplicata, e homogeneizadas com aproximadamente $15 \mathrm{~mL}$ de caldo ágar caseína-soja. Após a incubação das placas, em estufa a $30^{\circ} \mathrm{C}-35^{\circ} \mathrm{C}$, durante 24 horas, foi efetuada a contagem de colônias, à vista desarmada. Foram utilizadas as diluições da suspensão de cada microrganismo que continha aproximadamente de 100 a 150 unidades formadoras de colônia (UFC)/mL.

O mesmo procedimento foi efetuado para o bolor e a levedura que foram cultivados em meio inclinado de ágar Sabouraud-dextrose, incubando-se os tubos em estufa Fabbe ${ }^{\circledR}$ modelo 116 a $20{ }^{\circ} \mathrm{C}-25^{\circ} \mathrm{C}$, durante 48 horas. As placas para semeadura em profundidade foram homogeneizadas com caldo ágar Sabouraud-dextrose.

\subsubsection{Preparação das soluções de antibiótico}

Os padröes secundários de cloranfenicol e anfotericina B foram utilizados para a preparação das soluções. Para isto, $50 \mathrm{mg}$ de cada antibiótico foram pesados, dissolvidos e diluídos em $50 \mathrm{~mL}$ de solvente apropriado. $O$ 
cloranfenicol foi dissolvido em etanol e diluido em água destilada estéril. A anfotericina $B$ foi dissolvida em dimetilsulfóxido e diluída em água destilada estéril. A partir destas soluções foram efetuadas diluições em água destilada estéril para se obter concentraçōes de $4 \mu \mathrm{g} / \mathrm{mL}$ de cloranfenicol (bactérias) e de $0,5 \mu \mathrm{g} / \mathrm{mL}$ de anfotericina B para a levedura e $3 \mu \mathrm{g} / \mathrm{mL}$ de anfotericina $B$ para o bolor.

\subsubsection{Determinação da concentração inibitória mínima (CIM)}

Aliquotas de $1 \mathrm{~mL}$ de cada uma das suspensões com aproximadamente 100UFC/mL foram inoculadas em tubos contendo $9 \mathrm{~mL}$ de caldo caseínasoja para bactérias, em triplicata. Volumes de $1 \mathrm{~mL}$ de cada uma das soluções de EHEL também foram inoculados nos tubos. Paralelamente foram preparados, em triplicata, tubos controles positivos (contendo meio de cultura e microrganismo; e meio de cultura, microrganismo e solução aquosa de dimetilsulfóxido a 50\%) e controles negativos (contendo água destilada estéril; solução fisiológica estéril; meio de cultura; meio de cultura e solução de antibiótico; meio de cultura e amostra; e meio de cultura e solução aquosa de dimetilsulfóxido a $50 \%$ ). Os tubos foram incubados a $30{ }^{\circ} \mathrm{C}-35{ }^{\circ} \mathrm{C}$, durante 24 horas. A avaliação da inibição foi a ausência de turvação por meio de visualização macroscópica.

O mesmo procedimento foi efetuado para o bolor e a levedura utilizando-se $9 \mathrm{~mL}$ de caldo Sabouraud-dextrose, incubando-se os tubos em estufa Fabbe ${ }^{\circledR}$ modelo 116 a $20^{\circ} \mathrm{C}-25^{\circ} \mathrm{C}$, durante 48 horas.

\subsubsection{Atividade antioxidante}

\subsubsection{Detecção de substâncias antioxidantes por cromatografia em camada delgada}

Foram analisados os perfis cromatográficos da DV (subitem 4.4), do EHEL (subitem 4.4) e das frações do EHEL (subitem 4.5.1.9) em camada delgada para avaliação da presença de substâncias antioxidantes utilizando-se placas de silicagel $\mathrm{GF}_{254 \mathrm{~nm}}$ e fase móvel de tolueno / acetato de etila (93:7). 
O cromatograma foi observado à luz visivel e nebulizado com solução de betacaroteno (PRATT e MILLER, 1984).

4.7.3.2. Avaliação da atividade antioxidante por lipoperoxidação espontânea em homogenato de cérebro de rato

\subsection{Preparação do homogenato de cérebro de rato}

Ratos machos de linhagem Wistar, obtidos do Biotério do Conjunto das Químicas da Universidade de São Paulo, foram anestesiados adequadamente. O cérebro foi perfundido com 50 a $70 \mathrm{~mL}$ de tampão fosfato $\mathrm{pH} \mathrm{7,4} \mathrm{por} \mathrm{via} \mathrm{intracardíaca.} \mathrm{Os} \mathrm{ratos} \mathrm{foram} \mathrm{sacrificados} \mathrm{e} \mathrm{os}$ cérebros foram pesados e homogeneizados em quatro vezes o seu peso com volume de tampão fosfato $\mathrm{pH} \mathrm{7,4} \mathrm{com} \mathrm{o} \mathrm{auxilio} \mathrm{do} \mathrm{homogeneizador}$ tipo Potter-Elvehjem marca Marconi ${ }^{\circledR}$. Os homogenatos foram centrifugados durante 15 minutos a $3.000 \mathrm{rpm}$ a $4{ }^{\circ} \mathrm{C}$ em centrífuga refrigerada Hitachi ${ }^{\circledR}$ modelo Himac CR 20B2. O sobrenadante foi diluído em três vezes o seu volume com o tampão acima mencionado.

\subsection{Preparação de amostras}

Cinco concentrações diferentes do extrato EHEL em etanol 70\% (p/N) foram preparadas para a obtenção de curva de inibição.

\subsection{Desenvolvimento da coloração}

Um erlenmeyer de $25 \mathrm{~mL}$ foi utilizado para cada amostra. O solvente etanol $70 \%(\mathrm{p} N)$ recebeu o mesmo tratamento da amostra. Em cada erlenmeyer, foram colocados $3 \mathrm{~mL}$ do sobrenadante diluído do homogenato de cérebro de rato preparado anteriormente. Foram acrescentados $50 \mu \mathrm{L}$ de amostra. Dois tubos de plástico com capacidade para $10 \mathrm{~mL}$ foram utilizados para cada amostra a ser testada. Um mililitro de ácido tricloroacético (TCA) a 5\% $(\mathrm{p} N)$ foi transferido para cada tubo. Um mililitro de cada amostra foi transferido para um dos tubos de plástico, contendo o TCA a 5\%. Este o tubo foi denominado de $T_{0}$, pois determina a produção inicial de 
malonildialdeído. O conteúdo restante dos erlenmeyeres foi incubado por uma hora em banho-maria com agitador giratório New Brunswick ${ }^{\circledR}$ modelo $\mathrm{G} 76$ a $37{ }^{\circ} \mathrm{C}$ com velocidade 5 . Após uma hora, $1 \mathrm{~mL}$ do incubado foi transferido para o outro tubo plástico de centrifuga contendo o TCA a $5 \%$. Estes tubos foram denominados de $T_{1 \text { hora, medindo a produção de }}$ malonildialdeído após 1 hora. Todos os tubos foram centrifugados a 3.000 rpm, por 15 minutos em centrífuga clínica Incibrás ${ }^{\circledR}$ modelo Spin IV. A solução de ácido tiobarbitúrico (TBA) a $0,67 \%$ em água destilada foi preparada agitando-se por 30 minutos até completa dissolução. Um mililitro do sobrenadante foi retirado para tubos de vidro e adicionados de $1 \mathrm{~mL}$ de TBA a $0,67 \%$ em todos os tubos. O branco foi preparado transferindo-se o TBA a 0,67\% para um tubo de vidro contencio um miiiitiro de água destiliada. Os tubos permaneceram em um banno de água fervente durante 20 minutos Em seguida, pemaneceram am banho de galo por 20 minutos a posteriormente, por mais 20 minutos em temperatura amoiente. As leituras foram efetuadas em espectrofotometro UV-Visivel Hitachi modelo U3210 a $535 n m$. O cálculo da capacidade antioxidante (CAOx) é feito conforme a expressão:

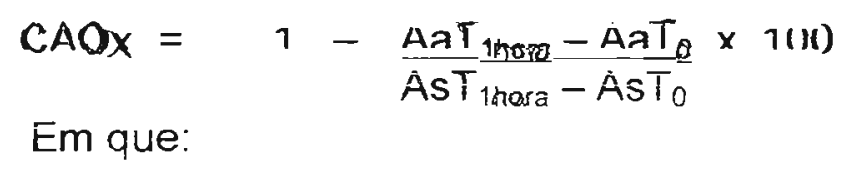

AaThora = absorvância da amostra na produção de malonildialdeído após 1 hora:

$\mathrm{AaT}_{0}$ = absorvância da amostra na produção inicial de malonildialdeído;

AsT 1 hora = absorvância do solvente na produçăo de maioniidiaideídio após 1 hora;

$A s T_{0}=$ absorvância do solvente na produção inicial de malonildiaideídio.

O resuitado é fornecido em percentual da capacidade de inibição espontânea da autoxidação (STOCKS, GUTIERIDGE. SHARP e DORMANAYY, 1974). 


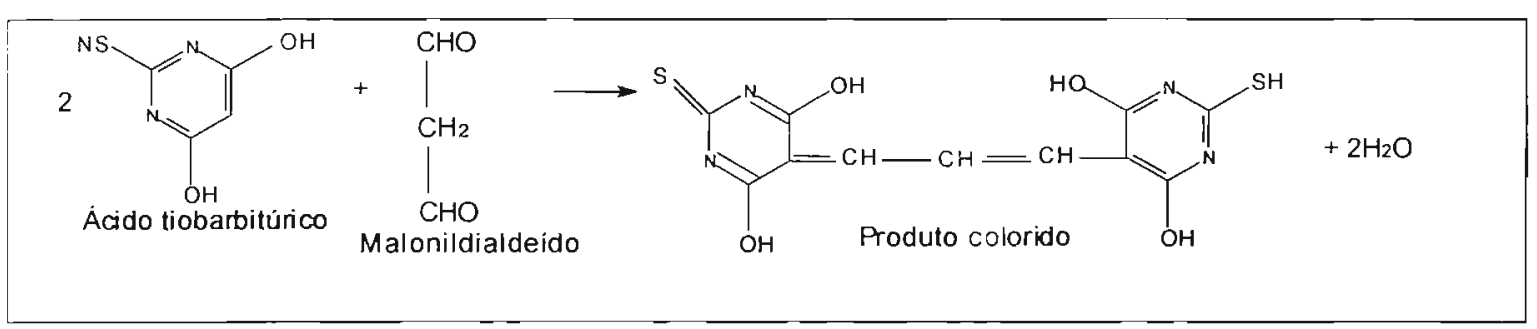

Figura 4 - Reação colorimétrica do ácido tiobarbitúrico (TBA) com malonildialdeído (MDA) para produzir um composto róseo que pode ser determinado espectrofotometricamente a $532-536 \mathrm{~nm}$.

\section{RESULTADOS}

\subsection{Estudo farmacobotânico}

\subsubsection{Caracterização macroscópica}

As folhas de Syzygium cumini (Figura 5A) foram obtidas de individuos de cerca de $10 \mathrm{~m}$ de altura, $3,6 \mathrm{~m}$ de diâmetro de copa e aproximadamente $1,10 \mathrm{~m}$ de diâmetro de tronco a $1,30 \mathrm{~m}$ da base.

As folhas, transformadas em droga, (Figura 5B) mostraram-se simples, opostas, glabras, inteiras, coriáceas, de contorno lanceolado ou lanceoladooblongo até elíptico, de 9 a $16 \mathrm{~cm}$ de comprimento e 3 a $5 \mathrm{~cm}$ de largura, de base simétrica e ápice acuminado. A superfície apresentou-se lisa, brilhante, discolor, com face adaxial de coloração verde-acastanhada e abaxial verde-pálido. A nervura mediana evidenciou-se saliente na face abaxial e a venação é camptódroma-bronquidódroma com as nervuras secundárias, tênues, unindo-se em arcus; formando a nervura marginal, a cerca de $1 \mathrm{~mm}$ do bordo. As nervuras mostraram-se impressas na face adaxial. A droga vegetal mostrou-se quebradiça, geralmente encurvada para a face adaxial, provida de diminutos pontos translúcidos pouco aparentes e de odor aromático característico. O sabor apresentou-se levemente adstringente.

As folhas pecioladas apresentaram peciolos de 1 a $3 \mathrm{~cm}$ de comprimento, levemente curvos ou torcidos. A secção transversal evidenciou-se canaletada e a inserção, marginal. 

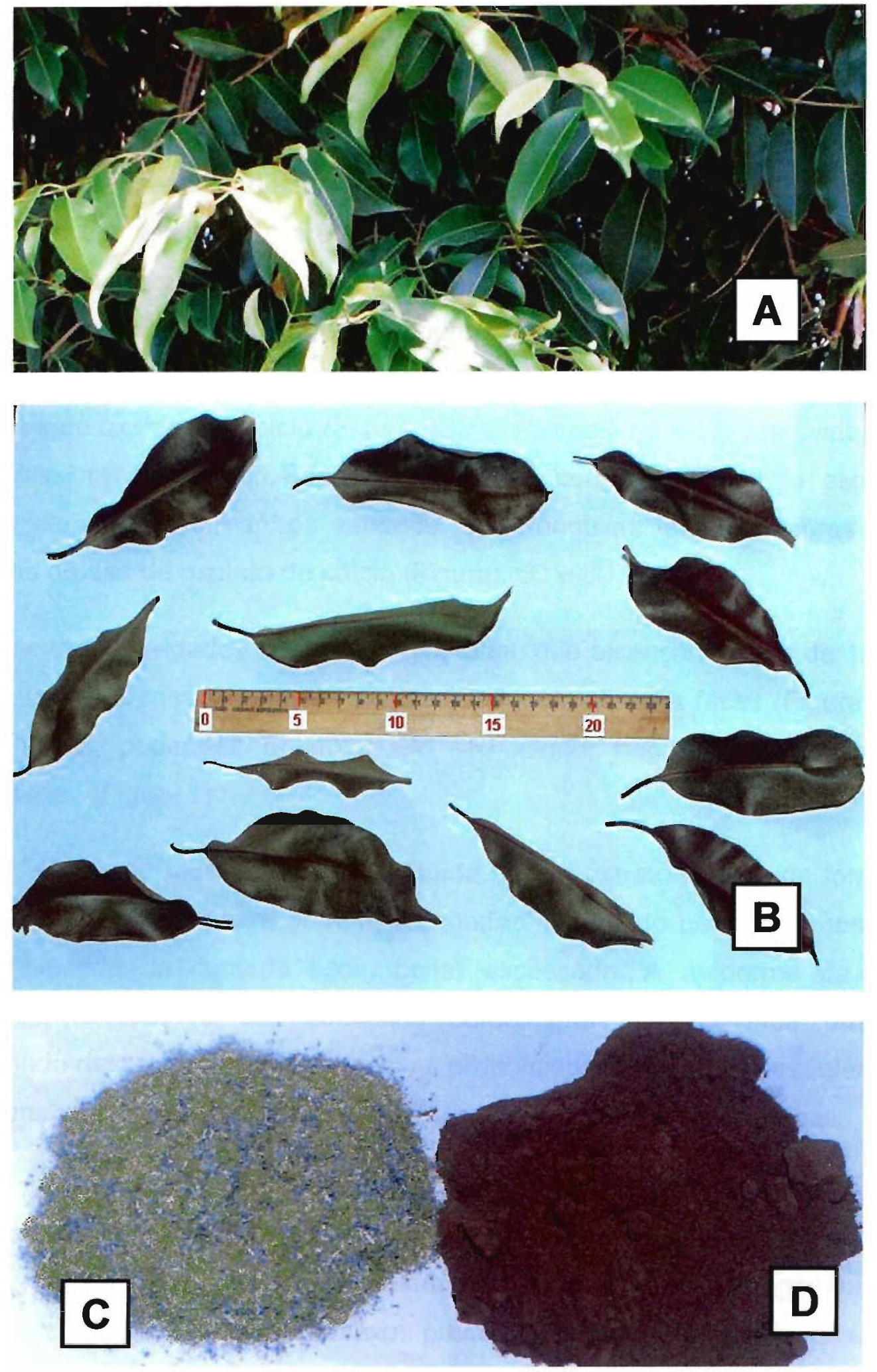

Figura $5-S$. cumini (L.) Skeels. Folhas. A. Material vegetal fresco. B. Droga vegetal. C. Droga vegetal pulverizada. D. Extrato hidroetanólico liofilizado. 


\subsubsection{Caracterização microscópica}

\subsubsection{Lâmina foliar}

A secção transversal da lâmina foliar, na região do terço mediano inferior, apresentou mesofilo dorsiventral (Figura 6A), constituido de um a dois estratos de células de parênquima paliçádico e de 13 a 16 camadas de parênquima lacunoso. O parênquima paliçádico alcançou cerca de 1/4 da espessura do mesofilo, sendo o segundo estrato de células mais curto. Na região paliçádica foram observadas células coletoras e idioblastos contendo drusas de oxalato de cálcio (Figura 6B). O parênquima lacunoso evidenciou células braciformes providas de projeções curtas, delimitando espaços intercelulares de tamanhos variados. O parênquima lacunoso apresentou várias drusas de oxalato de cálcio (Figuras 6C e 8B).

Numerosas cavidades secretoras globosas, que alcançam cerca de 1/6 da espessura do mesofilo, foram encontradas junto às duas faces (Figura 6D); por vezes, podem-se observar em seu interior fragmentos de paredes celulares. (Figura 7).

A epiderme da face adaxial, constituída de um estrato celular de forma e tamanho variável, quase sempre alongadas no sentido periclinal, mostrouse revestida de cutícula ligeiramente espessada. A epiderme da face abaxial apresentou características semelhantes às da face adaxial, diferindo desta por apresentar células proporcionalmente menores, além de estômatos dispostos no mesmo nível das demais células epidérmicas.

As folhas mostraram-se hipoestomáticas, sendo observados principalmente estômatos anomocíticos (Figura 8). Não foram observados tricomas. Em vista frontal, as células epidérmicas evidenciaram-se ligeiramente espessadas, com contorno variável, predominantemente ondeado, providas de cutícula lisa. As células epidérmicas que recobrem as cavidades secretoras, em número de dois, apresentaram a parede cornissural ligeiramente curva ou sinuosa (Figura 9). 


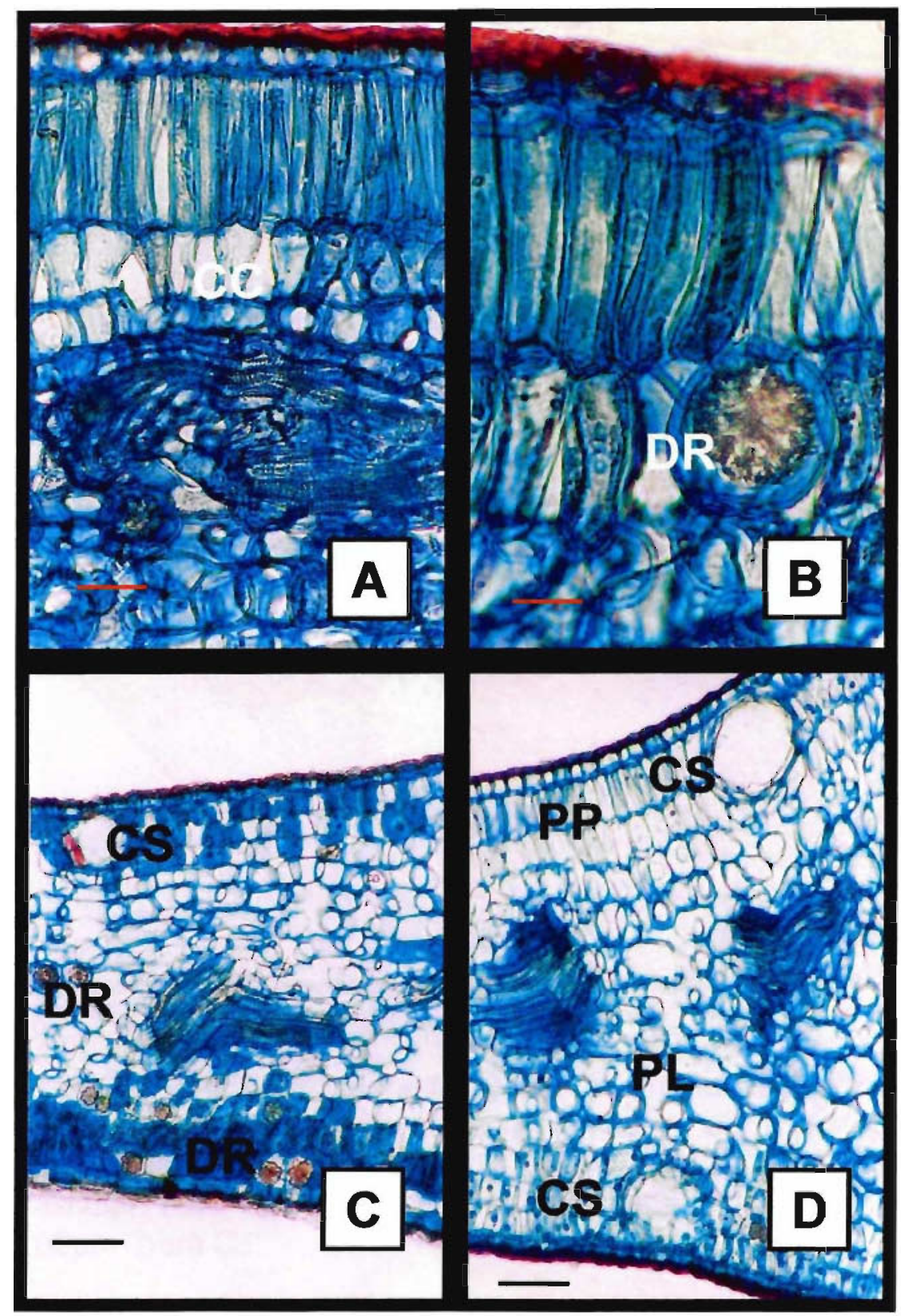

Figura 6. Syzygium cumini (L.) Skeels.. Folha. A, B, C e D. Seções transversais. A. mesofilo dorsiventral, com destaque às células coletoras (CC). B. Detalhe do mesofilo, evidenciando drusa de oxalato de cálcio (DR). C. Mesofilo dorsiventral, com destaque à cavidade secretora (CS) e drusas de oxalato de cálcio (DR) no parênquima lacunoso. D. Mesofilo dorsiventral, com destaque às cavidades secretoras (CS) em ambas as faces, parênquima paliçádico $(P P)$ e parênquima lacunoso $(P L)$. Escalas $=20 \mu \mathrm{m}$ para $A, 10 \mu \mathrm{m}$ para $\mathrm{B}, 40 \mu \mathrm{m}$ para $\mathrm{C}$ e $\mathrm{D}$. 


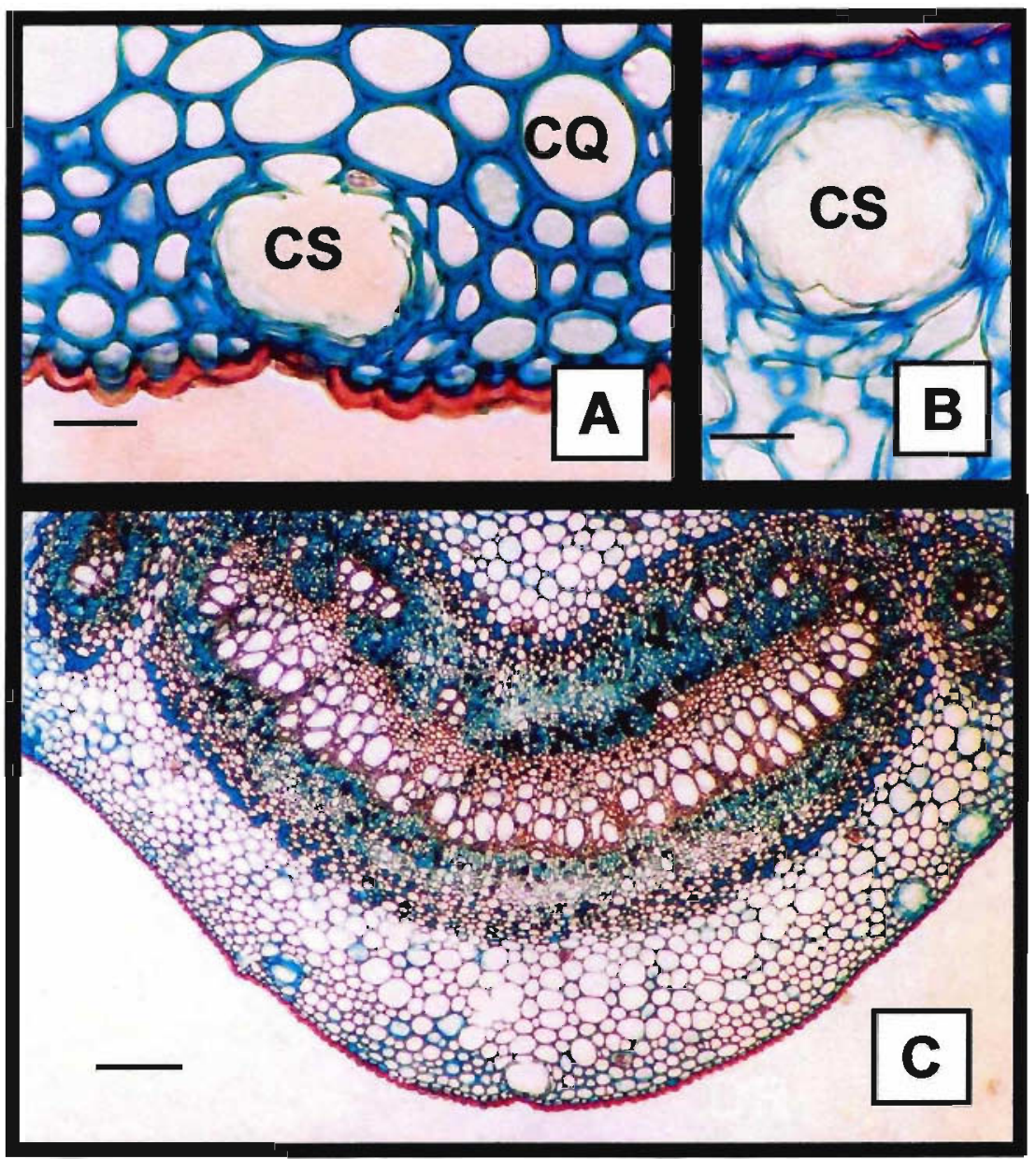

Figura 7 - Syzygium cumini (L.) Skeels. Folha. Nervura mediana. A. e B. Secções transversais da nervura mediana, com destaque às cavidades secretoras (CS) e colênquima (CQ). Azul de Astra. C. Detalhe do sistema vascular. Azul de Astra/safranina. Escalas $=20 \mu \mathrm{m}$ para A, $10 \mu \mathrm{m}$ para B e $100 \mu \mathrm{m}$ para $\mathrm{C}$. 


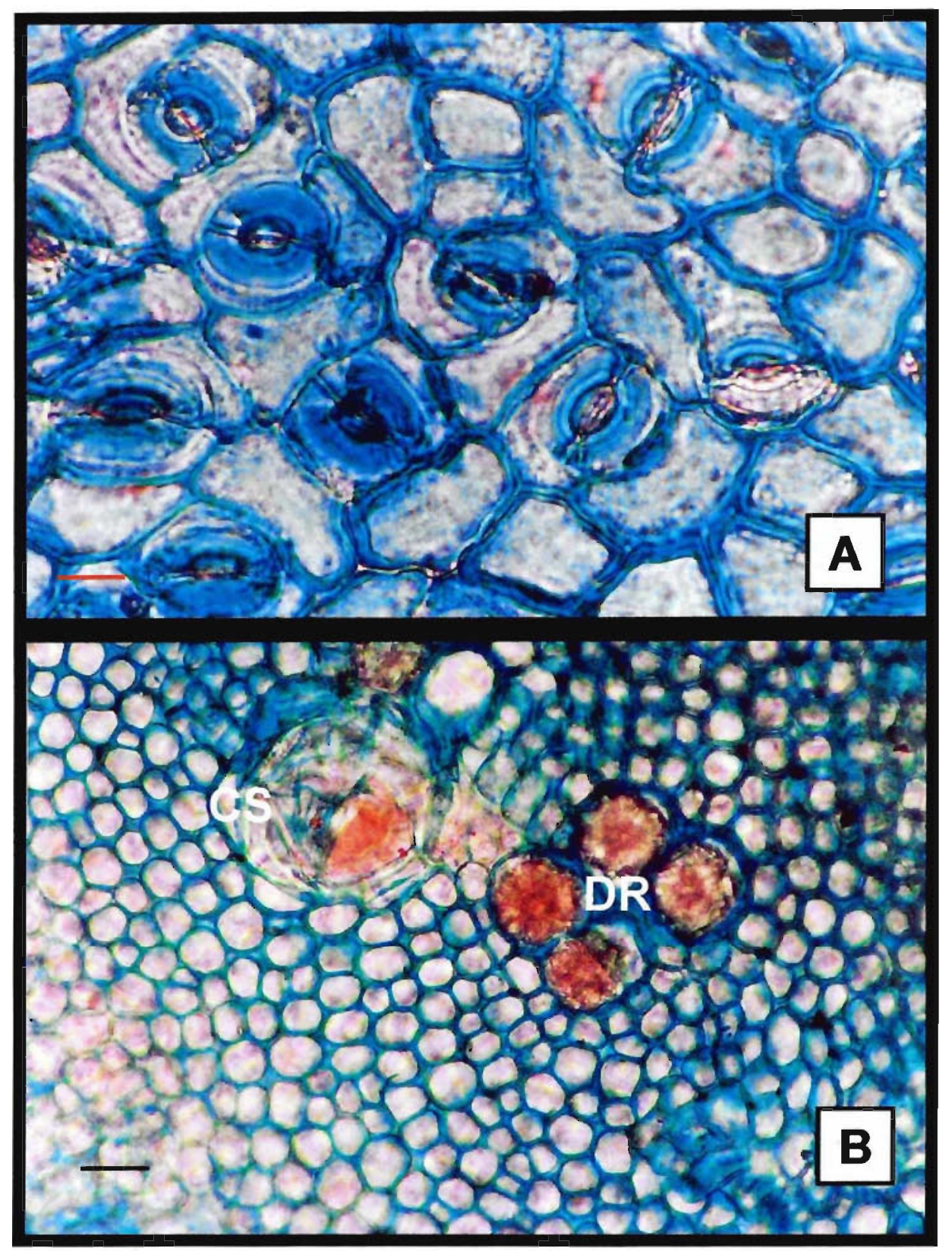

Figura 8 - Syzygium cumini (L.) Skeels. Folha. A. Vista frontal da face abaxial mostrando estômatos. Escala $=10 \mu \mathrm{m}$. B. Vista frontal da região paliçádica mostrando drusas (DR) e cavidade secretora (CS). Azul de astra. Escala $=20 \mu \mathrm{m}$. 


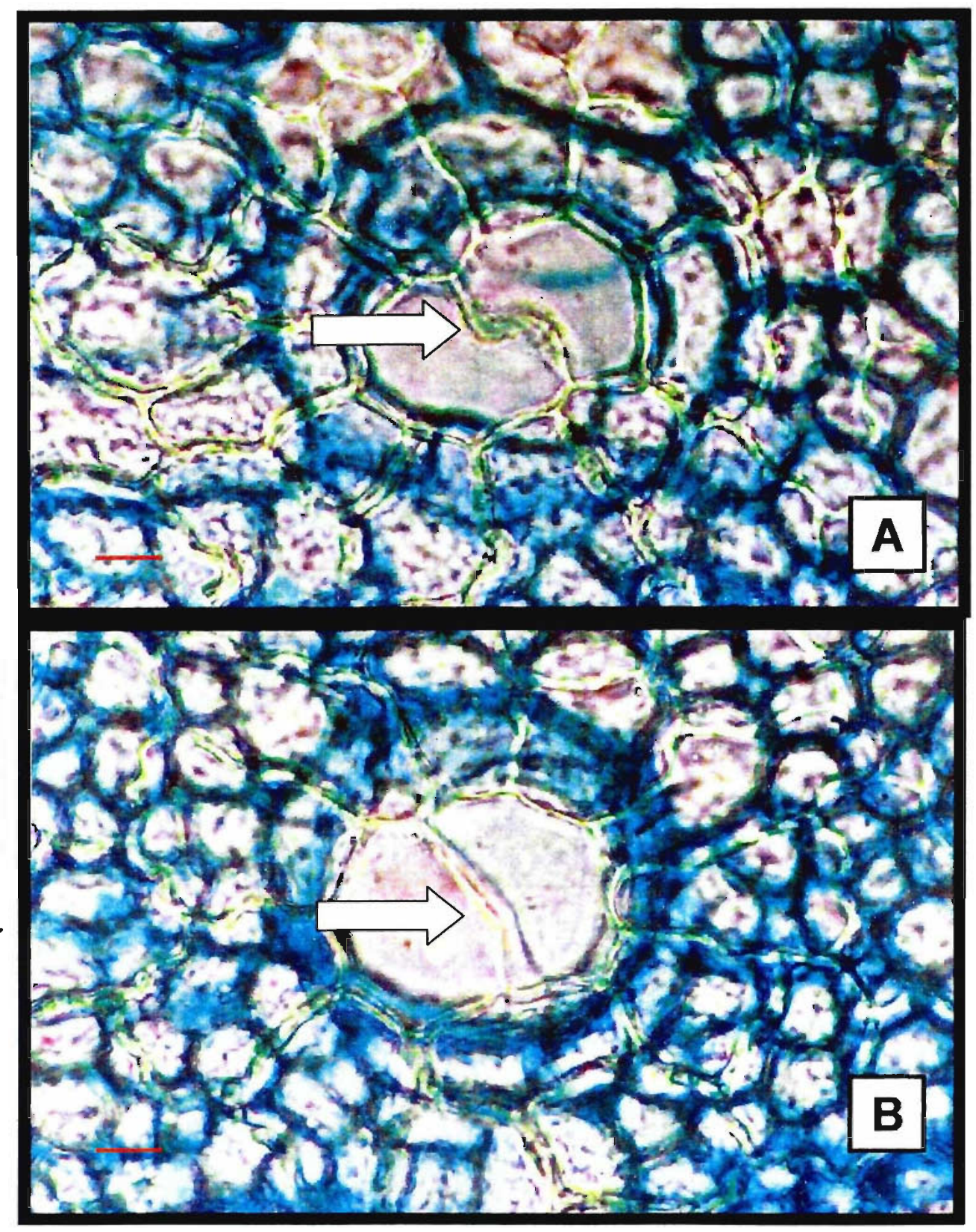

Figura 9 - Syzygium cumini (L.) Skeels. Folha. Vista frontal da face adaxial, com destaque para as células que recobrem as cavidades secretoras (seta). Azul de astra. Escala $=10 \mu \mathrm{m}$. 


\subsubsection{Nervura mediana}

A nervura mediana é bastante desenvolvida e apresenta-se côncavaconvexa. O sistema vascular, arqueado, mostra feixe bicolateral, envolvido parcialmente por esclerênquima. O xilema evidencia raios parenquimáticos, característico de crescimento secundário, e o floema externo é mais desenvolvido que o interno. Na região floemática externa observa-se grande número de inclusões de oxalato de cálcio.

\subsubsection{Pecíolo}

A estrutura geral do pecíolo não se modifica na região próxima à lâmina foliar, região mediana ou região próxima ao caule.

O sistema vascular principal apresentou-se em forma de arco aberto, envolvido por bainha fibrosa, exibindo floema intraxilemático. Numerosas drusas de oxalato de cálcio foram encontradas na região floemática. Podese observar a presença de dois a três feixes vasculares acessórios com crescimento secundário.

\subsubsection{Análise da droga vegetal pulverizada}

O pó da droga apresenta coloração castanho-esverdeada, odor agradável e sabor levemente adstringente (Figura 5C).

\subsection{Estudo químico}

\subsubsection{Análise do extrato hidroetanólico liofilizado (EHEL)}

O extrato hidroetanólico liofilizado (EHEL) apresenta coloração castanhoescura, odor agradável e sabor levemente adstringente, sendo higroscópico (Figura 5D). O rendimento do processo extrativo foi de $20,2 \%(p / p)$.

O rendimento do fracionamento do EHEL foi de $23 \%(\mathrm{p} / \mathrm{p})$ para a fração DCM, 26\% (p/p) para a fração ACE, 3\% (p/p) para a fração n-BUT e 45\% $(p / p)$ para a fração ETA. 


\subsubsection{Triagem fitoquímica}

O resultado da triagem fitoquímica da droga vegetal e do extrato hidroetanólico liofilizado de S. cumini está expresso na Tabela 5.

Tabela 5 - Triagem fitoquímica realizada com droga vegetal e com o extrato hidroetanólico liofilizado de Syzygium cumini (L.) Skeels.

\begin{tabular}{lcc}
\hline Grupos químicos & Droga vegetal & $\begin{array}{c}\text { Extrato hidroetanólico } \\
\text { liofilizado }\end{array}$ \\
\hline Alcalóides & - & - \\
\hline Antraderivados & - & - \\
\hline Cumarinas & - & - \\
\hline $\begin{array}{l}\text { Esteróides e } \\
\text { triterpenóides }\end{array}$ & + & + \\
\hline Flavonóides & ++ & +++ \\
\hline Óleo volátil & +++ & + \\
\hline Saponinas & ++ & +++ \\
\hline \multicolumn{1}{c}{$\begin{array}{l}\text { Indice de } \\
\text { espuma }\end{array}$} & 400 & 2000 \\
\hline $\begin{array}{l}\text { Atividade } \\
\text { hemolitica }\end{array}$ & Não hemolítca & Não hemolítico \\
\hline Taninos & & ++++ \\
\hline Intensidades: $(+)-$ fraca; $(++)-$ média; $(+++)-$ forte; $(-)-$ ausente.
\end{tabular}

\subsubsection{Análise cromatográfica em camada delgada}

As fases móveis 3 e 4 foram as que propiciaram as melhores separações dos compostos flavonoídicos. Os resultados estão apresentados nas figuras 10,11 e 12. 


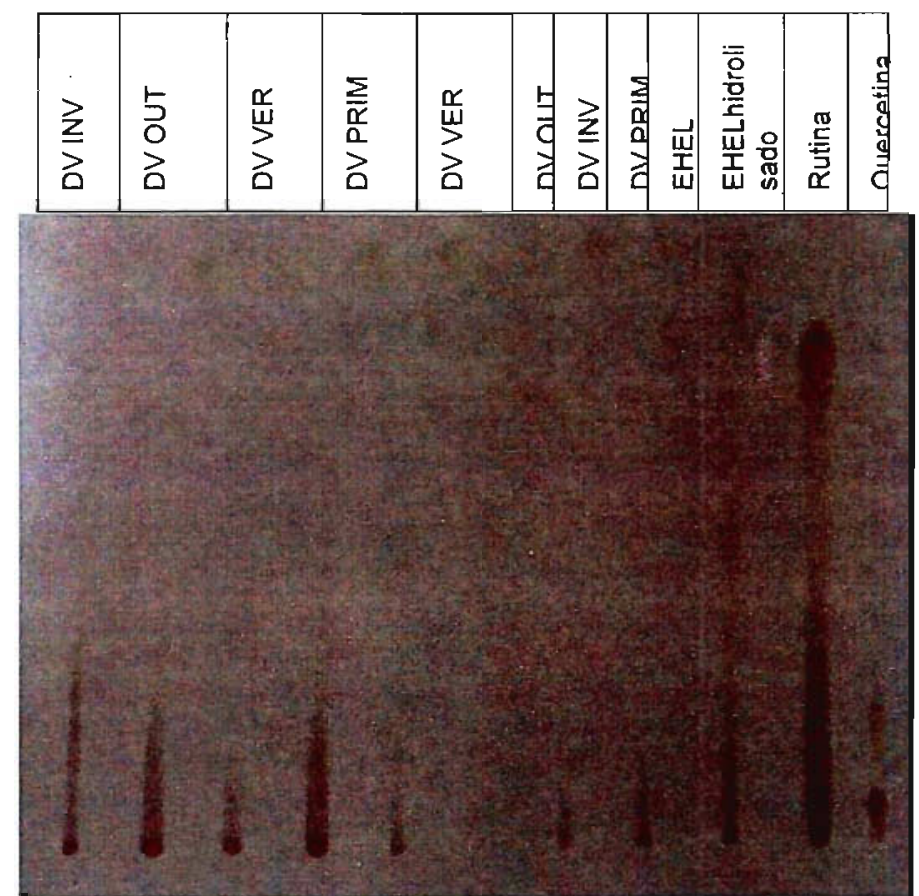

Figura 10: Cromatograma em camada delgada com silicagel - FM: acetato de etila/ácido acético (90:10) - revelador NP/PEG e observação na luz natural.

\begin{tabular}{|c|c|c|c|c|c|c|c|c|c|c|c|}
\hline$\underline{\underline{z}}$ & $\begin{array}{l}5 \\
0 \\
0 \\
3\end{array}$ & 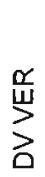 & $\begin{array}{l}\frac{z}{\bar{\gamma}} \\
0 \\
\frac{0}{2}\end{array}$ & $\sum_{\text {学 }}^{\frac{\pi}{3}}$ & $\begin{array}{l}5 \\
0 \\
\text { वे }\end{array}$ & 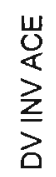 & 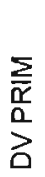 & $\underset{\underline{w}}{\underline{w}}$ & 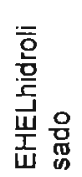 & 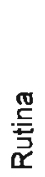 & 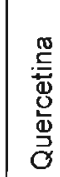 \\
\hline
\end{tabular}

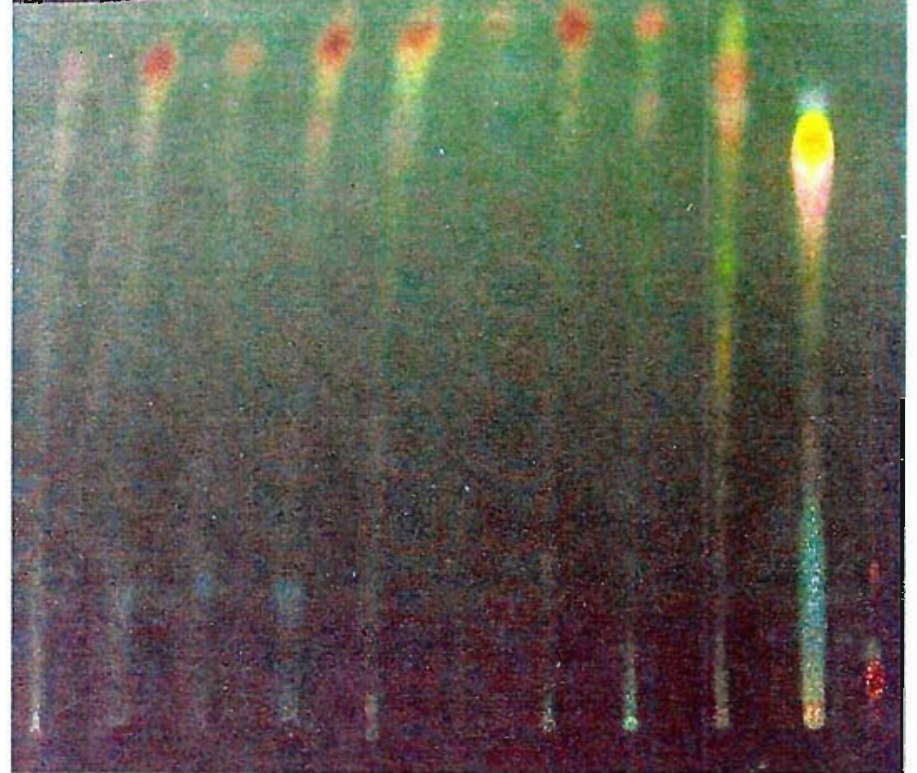

Figura 11: Cromatograma em camada delgada com silicagel - FM: acetato de etila/ácido acético (90:10) - revelador NP/PEG e observação na luz ultravioleta. 


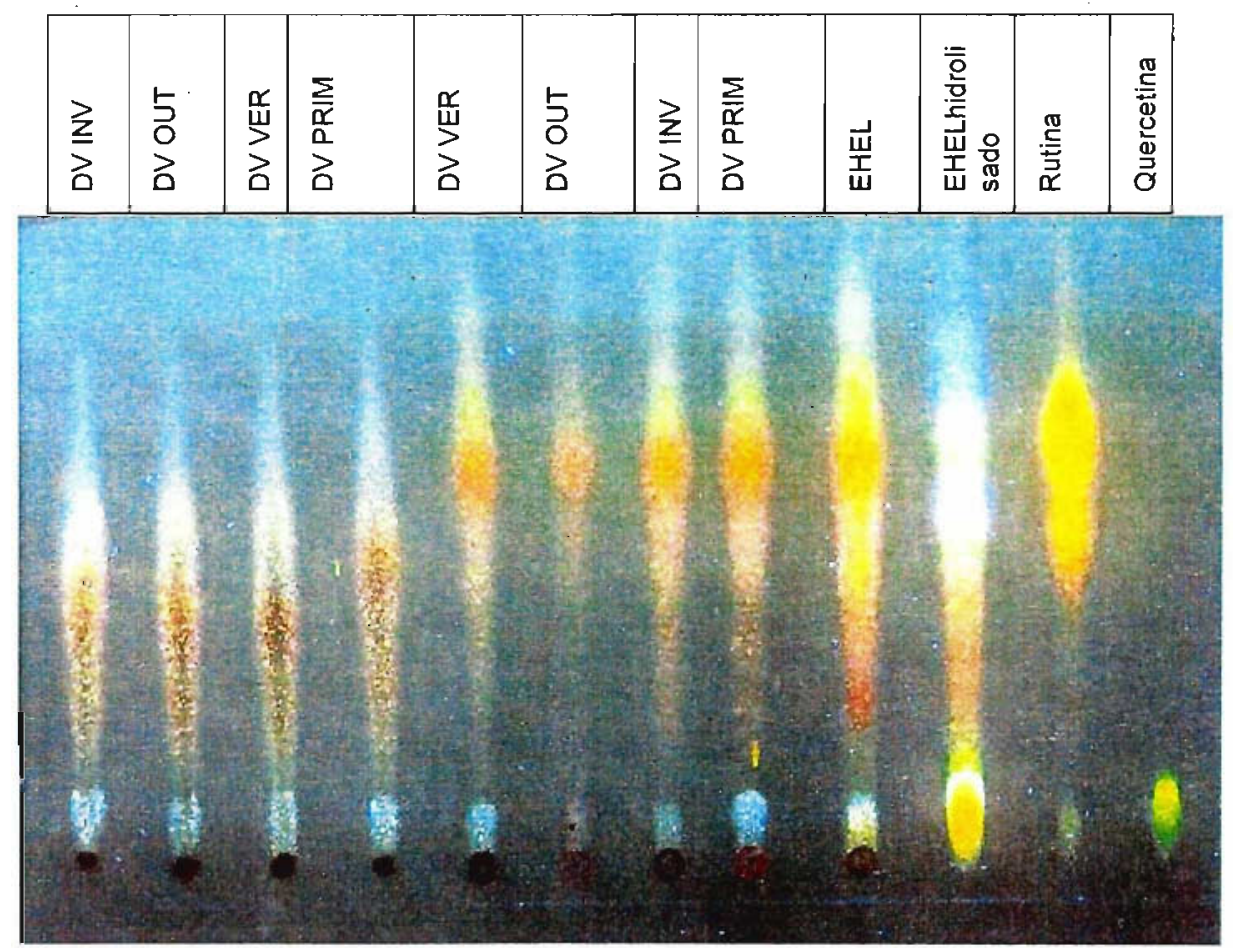

Figura 12: Cromatograma em camada delgada com celulose - FM: ácido acético $30 \%(100)$ - revelador NP/PEG e observação na luz ultravioleta.

A fase móvel 4 foi a que propiciou a melhor separação dos compostos saponínicos e terpenóides. Os resultados estão apresentados nas figuras 13 e 14. 


\begin{tabular}{|c|c|c|c|c|c|c|c|c|}
\hline 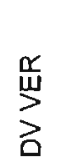 & 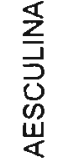 & $\begin{array}{l}5 \\
0 \\
3\end{array}$ & 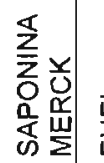 & $\overrightarrow{\underline{\Psi}}$ & 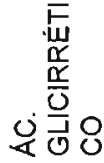 & $\frac{\text { z }}{\text { za }}$ & $\begin{array}{l}\frac{1}{2} \\
\frac{2}{2} \\
0 \\
\frac{0}{5} \\
\text { s }\end{array}$ & 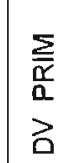 \\
\hline
\end{tabular}

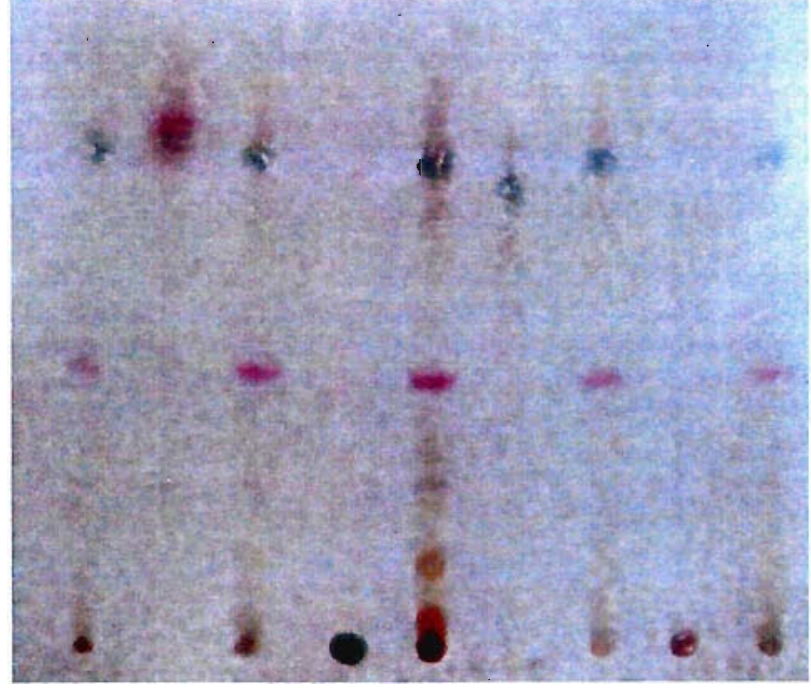

Figura 13: Cromatograma em camada delgada com silicagel - FM: clorofórmio/acetonalácido fórmico $(75: 16,5: 8,5)$ - revelador anisaldeido sulfúrico e observação na luz natural.

\begin{tabular}{|c|c|c|c|c|c|c|c|c|}
\hline$\stackrel{\text { 舀 }}{\text { 己 }}$ & 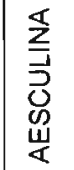 & $\begin{array}{l}5 \\
\text { ○ } \\
\text { 己 }\end{array}$ & 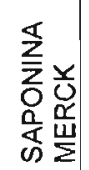 & $\underset{\mathrm{W}}{\mathrm{\Psi}}$ & 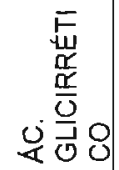 & 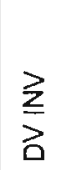 & $\begin{array}{l}\frac{1}{z} \\
z \\
0 \\
\frac{a}{\alpha} \\
\text { s }\end{array}$ & $\begin{array}{l}\frac{\sum}{d} \\
\alpha \\
\text { D }\end{array}$ \\
\hline
\end{tabular}

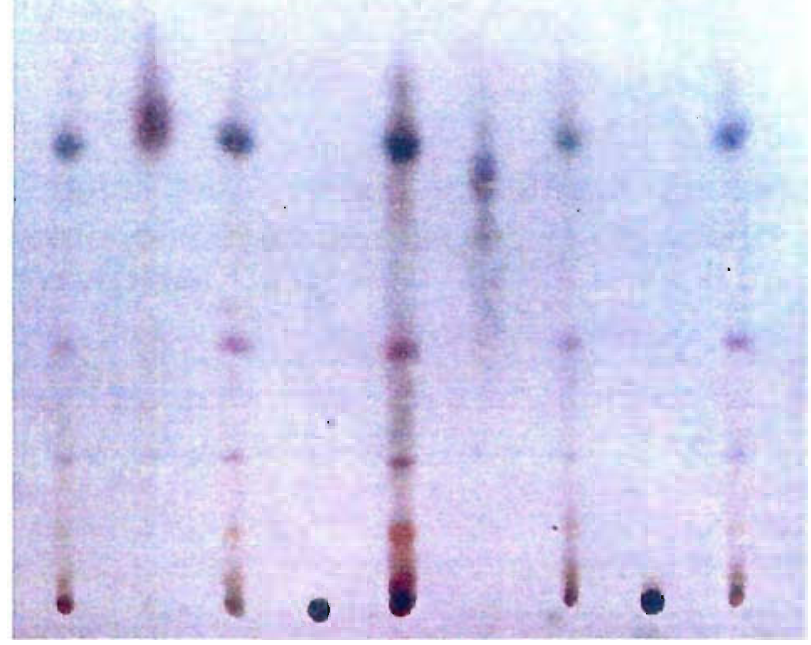

Figura 14: Cromatograma em camada delgada com silicagel - FM: clorofórmio/acetona/ácido fórmico $(75: 16,5: 8,5)$ - revelador vanilina sulfúrica e observação na luz natural. 


\subsection{4. Óleo volátil}

O óleo volátil extraido das folhas frescas de $S$. cumini na época da floração ou frutificação mostrou coloração amarelada e odor característico similar ao das folhas quando estas são esmagadas entre os dedos.

O índice de refração determinado a $20^{\circ} \mathrm{C}$ foi de 1,49094 .

A fase móvel 5 foi a que propiciou as melhores separações dos constituintes do óleo volátil. Os resultados estão apresentados nas figuras 15 e 16.

\begin{tabular}{|c|c|c|c|c|c|c|c|}
\hline $\begin{array}{l}\text { 을 } \\
\text { we } \\
\text { : } \\
\text { 은 } \\
\text { d }\end{array}$ & 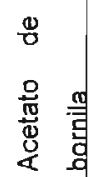 & 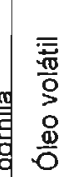 & 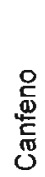 & 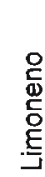 & \begin{tabular}{|c|}
$\frac{7}{0}$ \\
$\frac{70}{0}$ \\
$\frac{0}{0}$
\end{tabular} & $\overline{\bar{g}}$ & 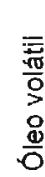 \\
\hline
\end{tabular}

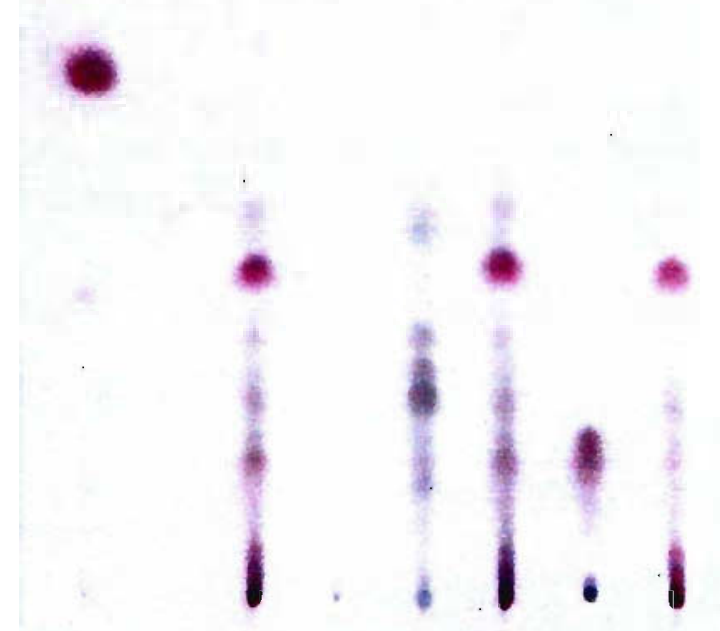

Figura 15: Cromatograma em camada delgada com silicagel - FM: tolueno/acetato de etila (93:7) - revelador vanilina sulfúrica e observação na luz natural. 


\begin{tabular}{|c|c|c|c|c|c|c|c|c|}
\hline 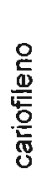 & 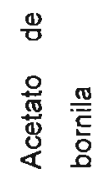 & 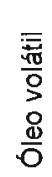 & 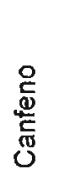 & 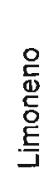 & 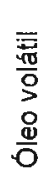 & 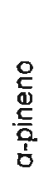 & $\begin{array}{l}\overline{7} \\
\frac{7}{0} \\
\\
0 \\
0 \\
0\end{array}$ & 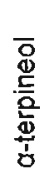 \\
\hline
\end{tabular}

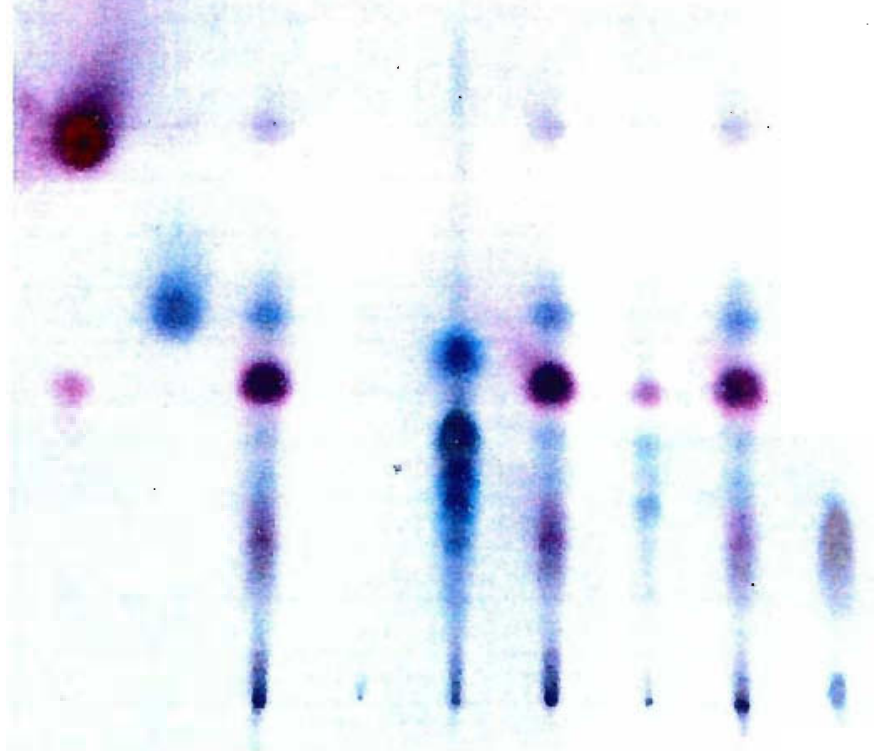

Figura 16: Cromatograma em camada delgada com silicagel - FM: tolueno/acetato de etila (93:7) - revelador anisaldeído sulfúrico e observação na luz natural.

O cromatograma obtido na cromatografia gasosa do óleo volátil pode ser visualizado na figura 17.

Abundância Relativa (\%)

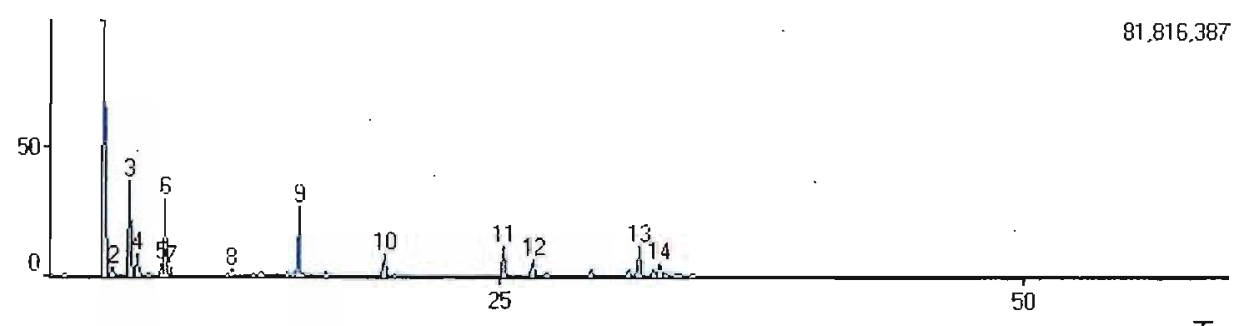

Tempo (minutos)

Figura 17: Cromatograma em fase gasosa do óleo volátil das folhas frescas de Syzygium cumini (L.) Skeels.

A tabela 6 mostra os treze constituintes identificados, bem como sua abundância relativa no óleo analisado. Os constituintes presentes em maior 
quantidade foram $\alpha$-pineno (36.54\%), $\alpha$-terpineol $(12,85 \%)$ e $\beta$-pineno $(12.74 \%)$.

Tabela 6: Composição química do óleo volátil das folhas frescas de Syzygium cumini (L.) Skeels e abundância relativa.

\begin{tabular}{ccc}
\hline Pico & Sustância & $(\mathbf{\%})$ \\
\hline 1 & $\alpha$-pineno & 36,54 \\
\hline 2 & canfeno & 0,80 \\
\hline 3 & $\beta$-pineno & 12,74 \\
\hline 4 & mirceno & 2,76 \\
\hline 5 & p-cimeno & 1,56 \\
\hline 6 & limoneno & 10,89 \\
\hline 7 & cis-ocimeno & 1,15 \\
\hline 8 & endo-fenchol & 0,77 \\
\hline 9 & $\alpha$-terpineol & 12,85 \\
\hline 10 & acetato de isobornila & 3,79 \\
\hline 11 & trans-cariofileno & 5,84 \\
\hline 13 & $\alpha$-humuleno & 3,10 \\
\hline 13 & Óxido de cariofileno & 5,13 \\
\hline 14 & Não ideritificado & 2,09 \\
\hline
\end{tabular}

\subsubsection{Doseamento de taninos}

Os resultados obtidos na determinação do teor de taninos na droga vegetal e no EHEL foram obtidos observando-se o valor médio de duas determinações e encontram-se expressos na tabela 7 .

Tabela 7: Teor de taninos na droga vegetal e no extrato preparado com folhas de Syzygium cumini (L.) Skeels.

\begin{tabular}{llllll}
\hline & DV-verăo & DV-outono & DV-inverno & DV-primavera & EHEL \\
\hline $\begin{array}{l}\text { Teor de } \\
\text { taninos }\end{array}$ & $\mathbf{3 , 4 7 \%}$ & $\mathbf{4 , 1 5 \%}$ & $\mathbf{3 , 9 9 \%}$ & $\mathbf{3 , 8 3 \%}$ & $\mathbf{1 3 , 9 7 \%}$ \\
\hline
\end{tabular}

$\mathrm{DV}=$ droga vegetal. EHEL = extrato hidroetanólico liofilizado 


\subsubsection{Doseamento de flavonóides}

Os resultados obtidos na determinação do teor de flavonóides na droga vegetal e no EHEL foram obtidos observando-se o valor médio de duas determinações e encontram-se expressos na tabela 8.

Tabela 8: Teor de flavonóides na droga vegetal e no extrato preparado com folhas de Syzygium cumini (L.) Skeels.

\begin{tabular}{lllllr}
\hline & $\begin{array}{l}\text { DV- } \\
\text { verão }\end{array}$ & $\begin{array}{l}\text { DV- } \\
\text { outono }\end{array}$ & $\begin{array}{l}\text { DV- } \\
\text { inverno }\end{array}$ & $\begin{array}{l}\text { DV- } \\
\text { primavera }\end{array}$ & EHEL \\
\hline $\begin{array}{l}\text { Teor de } \\
\text { flavonóides }\end{array}$ & $0,53 \%$ & $0,62 \%$ & $0,56 \%$ & $0,58 \%$ & $2,19 \%$ \\
\hline $\begin{array}{l}\text { DV = droga vegetal. EHEL = extrato hidroetanólico liofilizado } \\
\text { E }\end{array}$ & & &
\end{tabular}

\subsubsection{Doseamento de saponinas}

Os resultados obtidos na determinação do teor de saponinas na droga vegetal e no EHEL foram obtidos observando-se o valor médio de duas determinações e encontram-se expressos na tabela 9 .

Tabela 9: Teor de saponinas na droga vegetal e no extrato preparado com folhas de Syzygium cumini (L.) Skeels.

\begin{tabular}{lccccc}
\hline & DV-verão & DV-outono & DV-inverno & DV-primavera & EHEL \\
\hline $\begin{array}{l}\text { Teor de } \\
\text { saponinas }\end{array}$ & $4,22 \%$ & $8,64 \%$ & $8,22 \%$ & $5,09 \%$ & $10,92 \%$ \\
\hline DV = droga vegetal. EHEL & = extrato hidroetanólico liof́lizado & \\
\hline
\end{tabular}




\section{Estudo biológico}

\subsubsection{Toxicidade aguda}

No teste de toxicidade aguda em camundongos, a dose de $5 \mathrm{~g} / \mathrm{Kg}$ por via oral não provocou óbito de nenhum camundongo.

Nos primeiros 30 minutos após a administração observou-se que as fêmeas do grupo teste mostraram-se menos agitadas que as do grupo controle. Os machos do grupo teste também se tornaram menos agitados do que o grupo controle, porém em menor grau que as fêmeas.

Após a primeira hora, as fêmeas do grupo controle mostravam-se hiperativas, enquanto que as fêmeas do grupo teste e os dois grupos de machos continuavam pouco ativos.

As fêmeas do grupo teste ainda mostravam-se pouco ativas após duas horas da administração. Os machos do grupo controle também apresentavam comportamento semelhante às fêmeas, porém ligeiramente mais agitados que os do grupo teste.

Após três horas da administração, todos animais dos quatro grupos estavam sonolentos, permanecendo assim até a quarta hora de observação.

Após vinte e quatro horas, todas as fêmeas do grupo controle estavam ativas, enquanto que do grupo teste, só uma mostrava-se ativa. Os machos dos dois grupos mostravam-se ativos igualmente.

Após 48 horas, todos os camundongos dos quatro grupos mostravam-se igualmente ativos.

Não houve piloereção ou alteração da pele em nenhum dos animais durante o teste. Tampouco foram observados efeitos sobre a locomoção, respiração, contorção, tremores, convulsões ou cianose.

Os órgãos examinados macroscopicamente (coração, pulmão, fígado e rins) não apresentaram diferenças entre os grupos estudados.

A seguir, são apresentados as tabelas 10 a 17 e as figuras 18 a 25 comparativas entre os grupos controle e teste das fêmeas e machos em 
relação à massa média corpórea, consumo médio de ração, consumo médio de água e peso médio dos órgãos examinados .

Tabela 10 - Massa corpórea média dos camundongos fêmeas, controle e teste tratadas por via oral com extrato EHEL de Syzygium cumini (L.) Skeels na dose de $5 \mathrm{~g} / \mathrm{kg}$ de peso de animal, no ensaio de toxicidade aguda $(n=4)$.

\begin{tabular}{lcc}
\hline Dias & $\begin{array}{c}\text { Massa corpórea (g) } \\
\text { Controle }\end{array}$ & $\begin{array}{c}\text { Massa corpórea }(\mathbf{g}) \\
\text { Teste }\end{array}$ \\
\hline 0 & 32,55 & 32,23 \\
\hline 1 & 32,78 & 29,93 \\
\hline 2 & 32,51 & 28,89 \\
\hline 4 & 32,29 & 28,07 \\
\hline 6 & 32,31 & 27,41 \\
\hline 8 & 32,04 & 27,96 \\
\hline 10 & 31,88 & 28,61 \\
\hline 12 & 33,33 & 30,27 \\
\hline 14 & 33,72 & 31,39 \\
\hline
\end{tabular}

\section{Evolução da massa média corpórea nas fêmeas durante o teste}

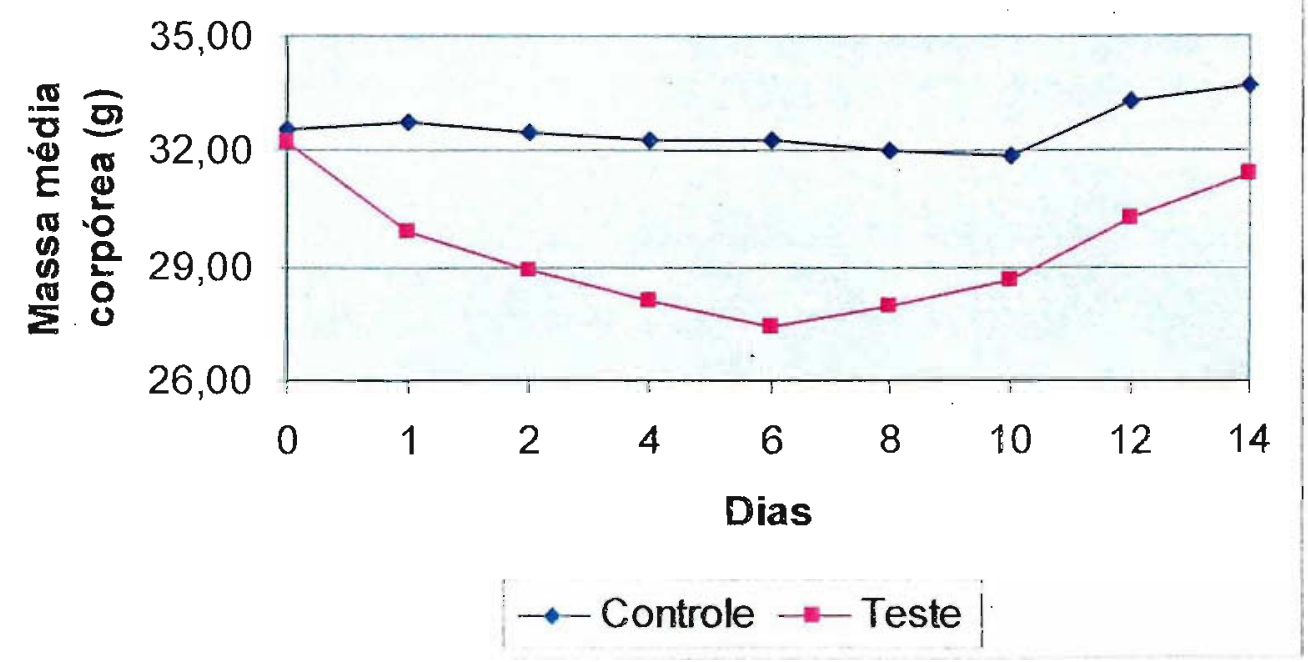

Figura 18 - Evolução da massa média corpórea dos camundongos fêmeas, controle e teste tratadas por via oral com extrato EHEL de Syzygium cumini (L.) Skeels na dose de $5 \mathrm{~g} / \mathrm{kg}$ de peso de animal, no ensaio de toxicidade aguda $(n=4)$. 
Tabela 11 - Massa corpórea média dos camundongos machos, controle e teste tratados por via oral com extrato EHEL de Syzygium cumini (L.) Skeels na dose de $5 \mathrm{~g} / \mathrm{kg}$ de peso de animal, no ensaio de toxicidade aguda $(n=5)$.

\begin{tabular}{lcc}
\hline Dias & $\begin{array}{c}\text { Massa corpórea }(\mathrm{g}) \\
\text { Controle }\end{array}$ & $\begin{array}{c}\text { Massa corpórea }(\mathrm{g}) \\
\text { Teste }\end{array}$ \\
\hline 0 & 41,71 & 42,47 \\
\hline 1 & 41,97 & 40,77 \\
\hline 2 & 41,76 & 40,95 \\
\hline 4 & 41,90 & 40,74 \\
\hline 6 & 41,87 & 40,81 \\
\hline 8 & 41,38 & 40,28 \\
\hline 10 & 41,34 & 41,17 \\
\hline 12 & 41,62 & 42,40 \\
\hline 14 & 41,34 & 42,17 \\
\hline
\end{tabular}

\section{Evolução da massa média corpórea nos machos durante o teste}

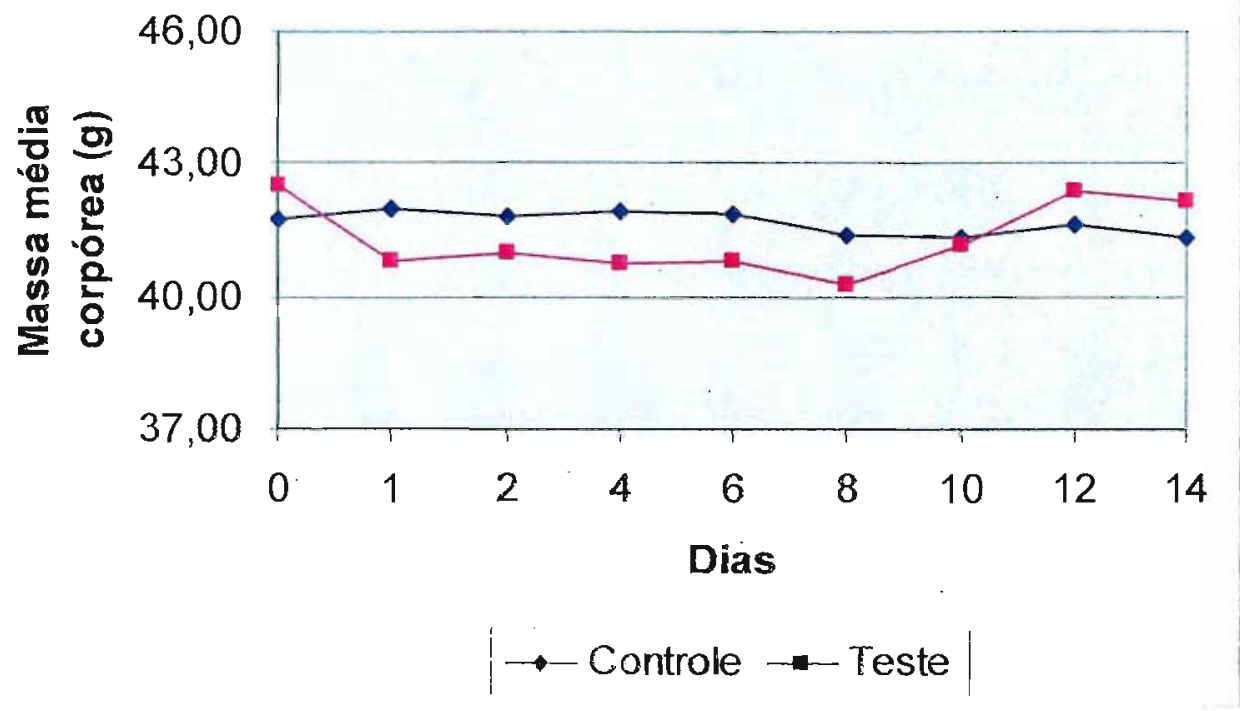

Figura 19 - Evolução da massa média corpórea dos camundongos machos, controle e teste tratados por via oral com exirato EHEL de Syzygium cumini (L.) Skeels na dose de $5 \mathrm{~g} / \mathrm{kg}$ de peso de animal, no ensaio de toxicidade aguda $(n=5)$. 
Tabela 12 - Consumo médio de ração por animal dos camundongos fêmeas, controle e teste tratadas por via oral com extrato EHEL de Syzygium cumini (L.) Skeels na dose de $5 \mathrm{~g} / \mathrm{kg}$ de peso de animal, no ensaio de toxicidade aguda $(n=4)$.

\begin{tabular}{lcc}
\hline Dias & $\begin{array}{c}\text { Consumo médio de ração }(\mathrm{g}) \\
\text { Controle }\end{array}$ & $\begin{array}{c}\text { Consumo médio de ração } \\
(\mathrm{g}) \\
\text { Teste }\end{array}$ \\
\hline 1 & 9,31 & 4,11 \\
\hline 2 & 6,92 & 4,04 \\
\hline 4 & 15,17 & 9,06 \\
\hline 6 & 13,28 & 13,31 \\
\hline 8 & 15,42 & 14,20 \\
\hline 10 & 16,26 & 16,06 \\
\hline 12 & 13,83 & 13,47 \\
\hline 14 & 11,78 & 12,52 \\
\hline
\end{tabular}

Comparação entre os grupos controle e teste do consumo de ração (fêmeas)

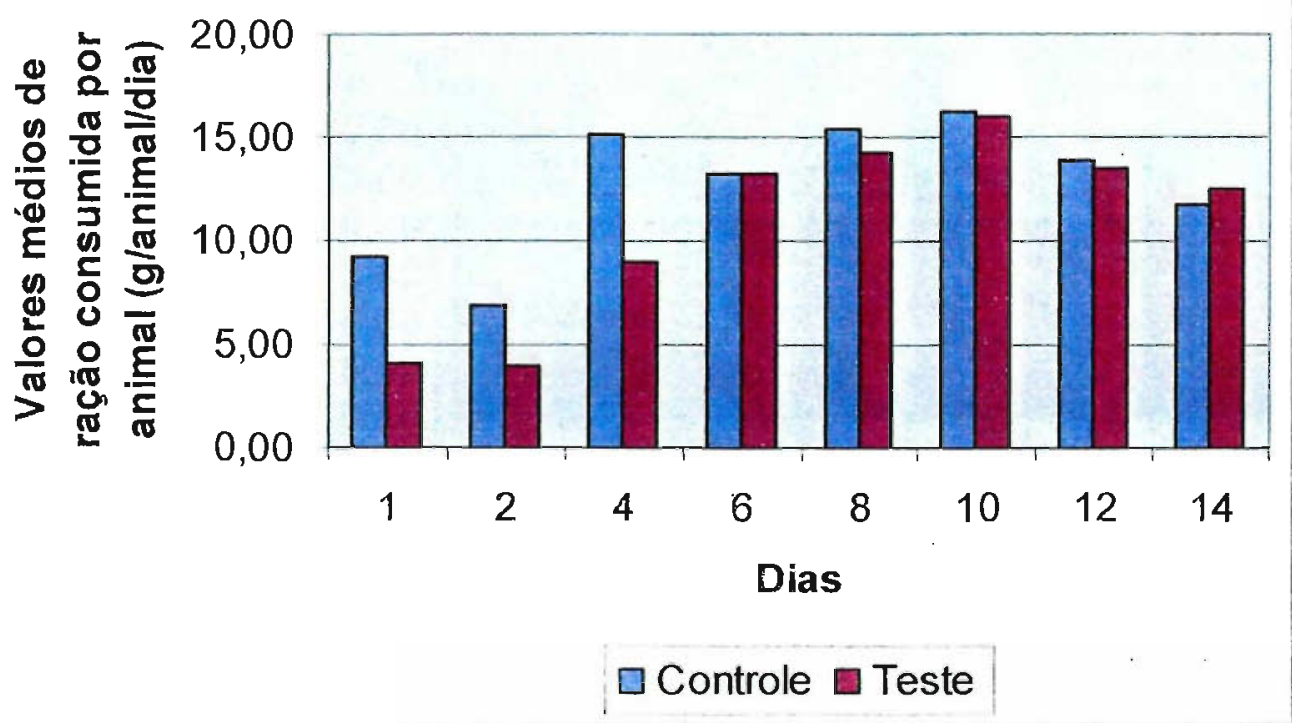

Figura 20 - Comparação do consumo médio de ração por animal dos camundongos fêmeas, controle e teste tratadas por via oral com extrato EHEL de Syzygium cumini (L.) Skeels na dose de $5 \mathrm{~g} / \mathrm{kg}$ de peso de animal, no ensaio de toxicidade aguda $(n=4)$. 
Tabela 13 - Consumo médio de ração por animal dos camundongos machos, controle e teste tratados por via oral com extrato EHEL de Syzygium cumini (L.) Skeels na dose de $5 \mathrm{~g} / \mathrm{kg}$ de peso de animal, no ensaio de toxicidade aguda $(n=5)$.

Dias

Consumo médio de ração Consumo médio de ração

(g)

(g)

Controle

Teste

\begin{tabular}{lcc}
\hline 1 & 14,08 & 6,53 \\
\hline 2 & 10,82 & 8,69 \\
\hline 4 & 27,43 & 20,33 \\
\hline 6 & 26,11 & 21,00 \\
\hline 8 & 25,33 & 22,40 \\
\hline 10 & 26,70 & 18,68 \\
\hline 12 & 22,21 & 25,41 \\
\hline 14 & 22,59 & 19,05 \\
\hline
\end{tabular}

\section{Comparação entre os grupos controle e teste no consumo de ração (machos)}

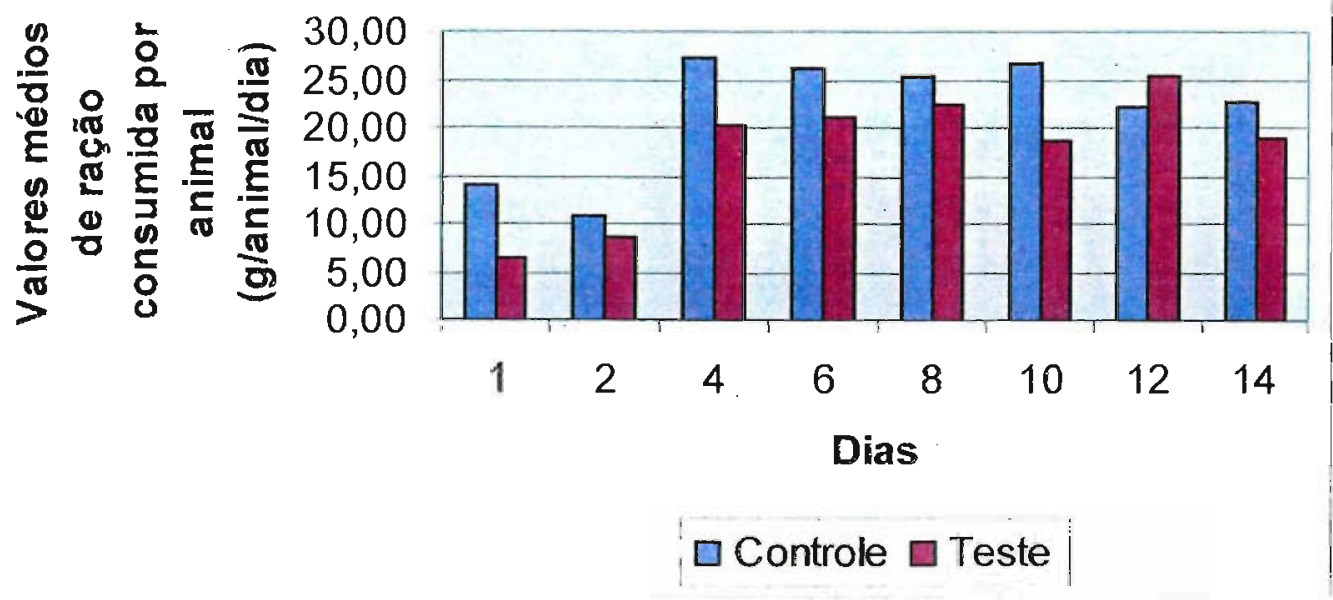

Figura 21 - Comparação do consumo médio de ração por animal dos camundongos machos, controle e teste tratados por via oral com extrato EHEL de Syzygium cumini (L.) Skeels na dose de $5 \mathrm{~g} / \mathrm{kg}$ de peso de animal, no ensaio de toxicidade aguda $(n=5)$. 
Tabela 14 - Consumo médio de água por animal dos camundongos fêmeas, controle e teste tratadas por via oral com extrato EHEL de Syzygium cumini (L.) Skeels na dose de $5 \mathrm{~g} / \mathrm{kg}$ de peso de animal, no ensaio de toxicidade aguda $(n=4)$.

\begin{tabular}{lcc}
\hline Dias & $\begin{array}{c}\text { Consumo médio de água }(\mathrm{mL}) \\
\text { Controle }\end{array}$ & $\begin{array}{c}\text { Consumo médio de água } \\
(\mathrm{mL}) \\
\text { Teste }\end{array}$ \\
\hline 1 & 6,3 & 3,0 \\
\hline 2 & 6,3 & 4,0 \\
\hline 4 & 15 & 7,0 \\
\hline 6 & 7,5 & 8,8 \\
\hline 8 & 12,5 & 11,3 \\
\hline 10 & 15,0 & 11,3 \\
\hline 12 & 16,3 & 11,3 \\
\hline 14 & 11,3 & 10,0 \\
\hline
\end{tabular}

Comparação entre os grupos controle e teste do consumo de água (fêmeas)

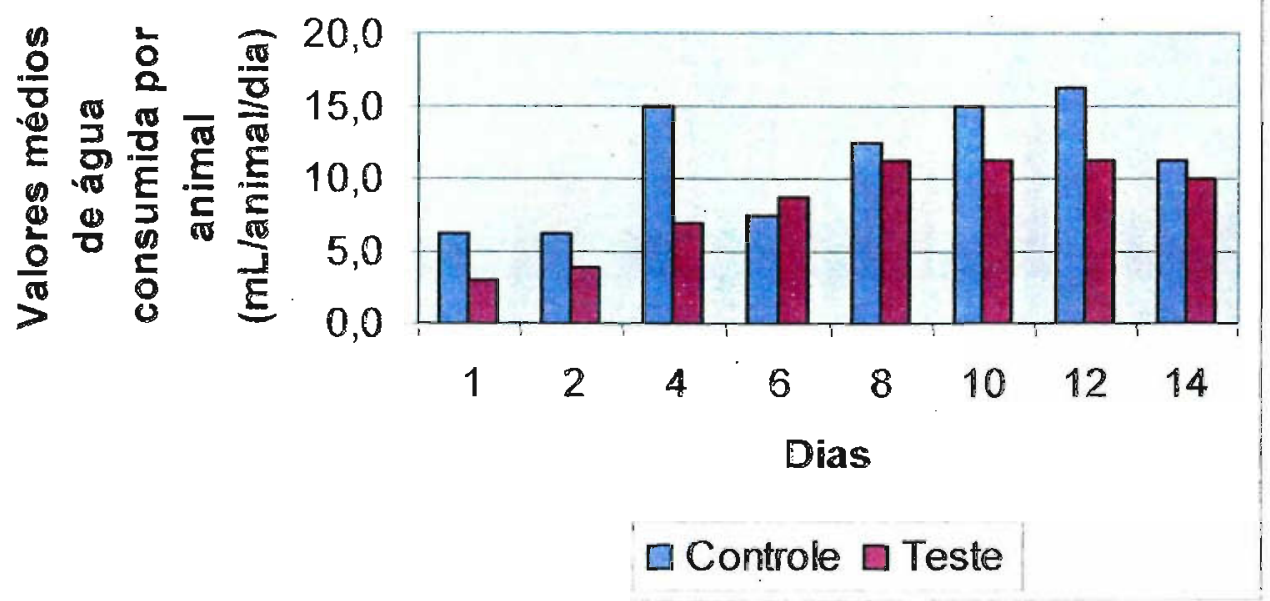

Figura 22 - Comparação do consumo médio de água por animal dos camundongos fêmeas, controle e leste tratadas por via oral com extrato EHEL de Syzygium cumini (L.) Skeels na dose de $5 \mathrm{~g} / \mathrm{kg}$ de peso de animal, no ensaio de toxicidade aguda $(n=4)$. 
Tabela 15 - Consumo médio de água por animal dos camundongos machos, controle e teste tratados por via oral com extrato EHEL de Syzygium cumini (L.) Skeels na dose de $5 \mathrm{~g} / \mathrm{kg}$ de peso de animal, no ensaio de toxicidade aguda $(n=5)$.

\begin{tabular}{lcc}
\hline Dias & $\begin{array}{c}\text { Consumo médio de água } \\
(\mathrm{mL}) \\
\text { Controle }\end{array}$ & $\begin{array}{c}\text { Consumo médio de água } \\
(\mathrm{mL}) \\
\text { Teste }\end{array}$ \\
\hline 1 & 36,0 & 4,0 \\
\hline 2 & 8,0 & 11,0 \\
\hline 4 & 15,0 & 23,0 \\
\hline 6 & 17,0 & 12,0 \\
\hline 8 & 18,0 & 18,0 \\
\hline 10 & 22,0 & 19,0 \\
\hline 12 & 17,0 & 18,0 \\
\hline 14 & 15,0 & 16,0 \\
\hline
\end{tabular}

\section{Comparação entre os grupos controle e teste do consumo de água (machos)}

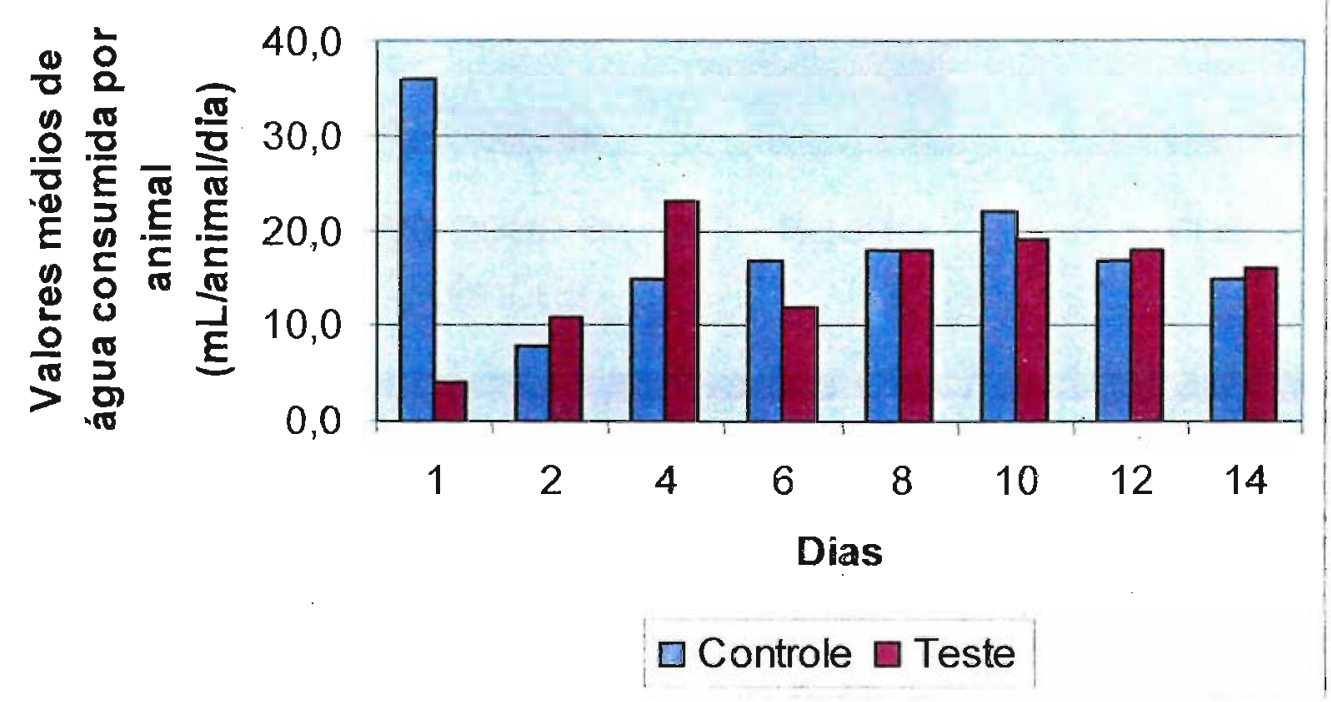

Figura 23 - Comparação do consumo médio de água por animal dos camundongos machos, controle e teste tratados por via oral com extrato EHEL de Syzygium cumini (L.) Skeels na dose de $5 \mathrm{~g} / \mathrm{kg}$ de peso de animal, no ensaio de toxicidade aguda $(n=5)$. 
Tabela 16 - Massa média dos órgãos dos camundongos fêmeas, controle e teste tratadas por via oral com extrato EHEL de Syzygium cumini (L.) Skeels na dose de $5 \mathrm{~g} / \mathrm{kg}$ de peso de animal, no ensaio de toxicidade aguda $(n=4)$.

\begin{tabular}{lcc}
\hline Órgão & $\begin{array}{c}\text { Massa média }(\mathrm{g}) \\
\text { Controle }\end{array}$ & $\begin{array}{c}\text { Massa média }(\mathrm{g}) \\
\text { Teste }\end{array}$ \\
\hline $\begin{array}{l}\text { Coração e } \\
\text { pulmões }\end{array}$ & 0,52 & 0,55 \\
\hline Figado & 1,94 & 1,65 \\
\hline Rins & 0,50 & 0,40 \\
\hline
\end{tabular}

\section{Comparação entre os grupos controle e teste da massa média dos órgãos (fêmeas)}

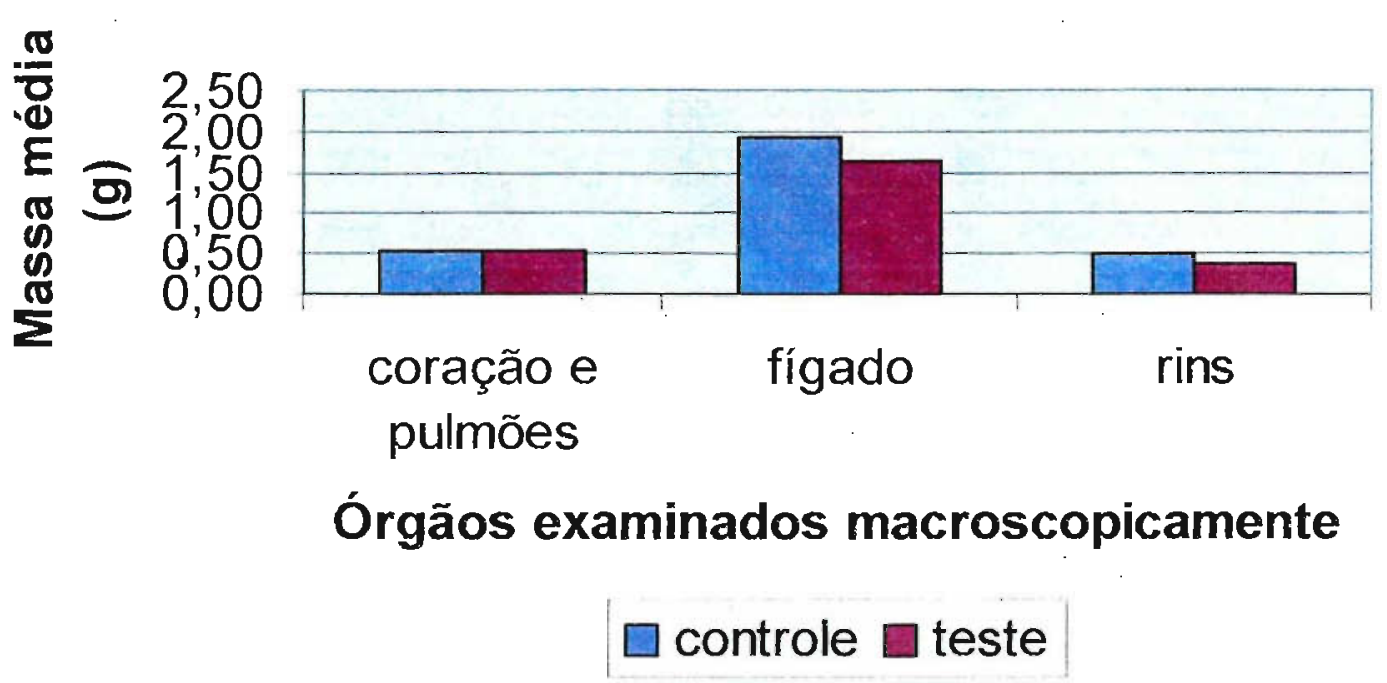

Figura 24 - Comparação da massa média dos órgãos dos camundongos fêmeas, controle e teste tratadas por via oral com extrato EHEL de Syzygium cumini (L.) Skeels na dose de $5 \mathrm{~g} / \mathrm{kg}$ de peso de animal, no ensaio de toxicidade aguda $(n=4)$. 
Tabela 17 - Massa média dos órgãos dos camundongos machos, controle e teste tratados por via oral com extrato EHEL de Syzygium cumini (L.) Skeels na dose de $5 \mathrm{~g} / \mathrm{kg}$ de peso de animal, no ensaio de toxicidade aguda $(n=5)$.

\begin{tabular}{lcc}
\hline Órgão & $\begin{array}{c}\text { Massa média (g) } \\
\text { Controle }\end{array}$ & $\begin{array}{c}\text { Massa média (g) } \\
\text { Teste }\end{array}$ \\
\hline $\begin{array}{l}\text { Coração e } \\
\text { pulmões }\end{array}$ & 0,66 & 0,64 \\
\hline Figado & 2,33 & 2,32 \\
\hline Rins & 0,71 & 0,60 \\
\hline
\end{tabular}

\section{Comparação entre os grupos controle e teste da massa média dos órgãos (machos)}

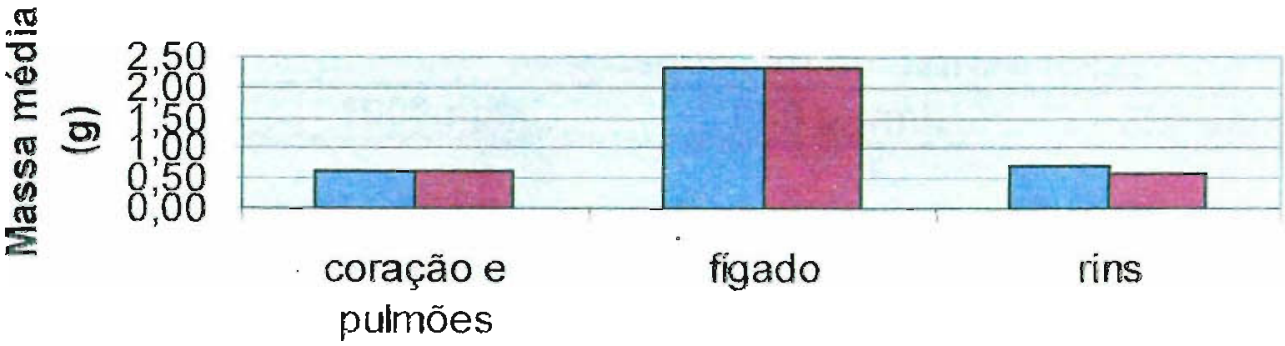

Órgãos examinados macroscopicamente

$\square$ controle $\square$ teste

Figura 25 - Comparaçăo da massa média dos órgãos dos camundongos machos, controle e teste tratados por via oral com extrato EHEL de Syzygium cumini (L.) Skeels na dose de $5 \mathrm{~g} / \mathrm{kg}$ de peso de animal, no ensaio de toxicidade aguda $(n=5)$. 


\subsubsection{Atividade antimicrobiana}

No método utilizado para a determinação da concentração inibitória mínima (CIM) que foi o da diluição em meio líquido, o parâmetro avaliado é a ausência de turvação no meio líquido que indica a inibição do crescimento do microrganismo.

Desde a concentração de $250 \mu \mathrm{g} / \mathrm{mL}$ do EHEL, a presença de taninos provocou a turvação do meio, dificultando a visualização do crescimento microbiano. Assim sendo, realizou-se uma subcultura em tubo como recurso para a deteç̧ão do crescimento microbiano. Constatou-se que as concentrações de até $1000 \mu \mathrm{g} / \mathrm{mL}$ do EHEL não possuem atividade biocida, uma vez que ocorreu o crescimento nos tubos, em todas as concentrações utilizadas, indicando que os microrganismos testados não foram inviabilizados. Os resultados são apresentados na tabela 18.

Tabela 18 - Atividade antimicrobiana do EHEL das folhas de Syzygium cumini (L.) Skeels pelo método de diluição em meio líquido em tubos.

\begin{tabular}{lcccc} 
& \multicolumn{3}{c}{ Concentração do exirato EHEL } \\
\hline Microrganismos & $\mathbf{1 0 0 0 \mu \mathrm { g } / \mathrm { mL }}$ & $\mathbf{5 0 0 \mu \mathrm { g } / \mathrm { mL }}$ & $\mathbf{2 5 0} \mathbf{\mu g} / \mathbf{m L}$ \\
\hline $\begin{array}{l}\text { Staphylococcus } \\
\text { aureus }\end{array}$ & + & + & + \\
\hline Escherichia coli & & + & + & + \\
\hline Candida albicans & + & + & + \\
\hline Aspergillus niger & + & + & + \\
\hline
\end{tabular}

$(+)$ com crescimento

(-) sem crescimento

\subsubsection{Atividade antioxidante}

O resultado obtido na cromatografia em camada delgada para a detecção de substâncias antioxidantes é mostrado na figura 26. 


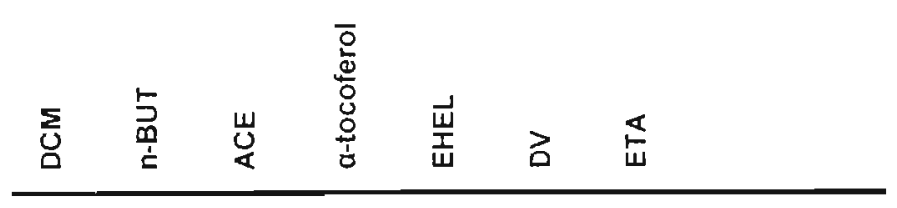

Figura 26: Cromatograma em camada delgada com silicagel - FM: clorofórmio/acetona/ácido fórmico $(75: 16,5: 8,5)$ - revelador betacaroteno e observação na luz natural.

O extrato hidroetanólico liofilizado das folhas de $S$. cumini apresentou a capacidade de inibir a lipoperoxidação no homogenato de cérebro de ratos. Os resultados são apresentados na tabela 19 e na figura 27.

Tabela 19 - Médias aritméticas e os desvios padrão da determinação da capacidade antioxidante (CAOx) do EHEL das folhas de Syzygium cumini (L.) Skeels.

\begin{tabular}{llll}
\hline $\begin{array}{l}\text { Concentração no } \\
\text { meio de reação } \\
(\mu \mathrm{g} / \mathrm{mL})\end{array}$ & $\begin{array}{l}\text { 1/Concentração } \\
\text { no meio de } \\
\text { reação }(\mathrm{mL} / \mu \mathrm{\mu g})\end{array}$ & $\begin{array}{l}\text { Média da } \\
\text { Capacidade } \\
\text { antioxidante }(\%)\end{array}$ & $\begin{array}{l}\text { Desvio } \\
\text { padrão da } \\
\text { capacidade } \\
\text { antioxidante }\end{array}$ \\
\hline 75,000 & 0,0133 & 100,0000 & 0,0000 \\
\hline 62,500 & 0,0160 & 86,1373 & 1,1553 \\
\hline 37,500 & 0,0267 & 71,7542 & 1,5788 \\
\hline 18,750 & 0,0533 & 47,6557 & 4,5092 \\
\hline 9,375 & 0,1067 & 37,4104 & 1,2224 \\
\hline
\end{tabular}




\section{Capacidade antioxidante}

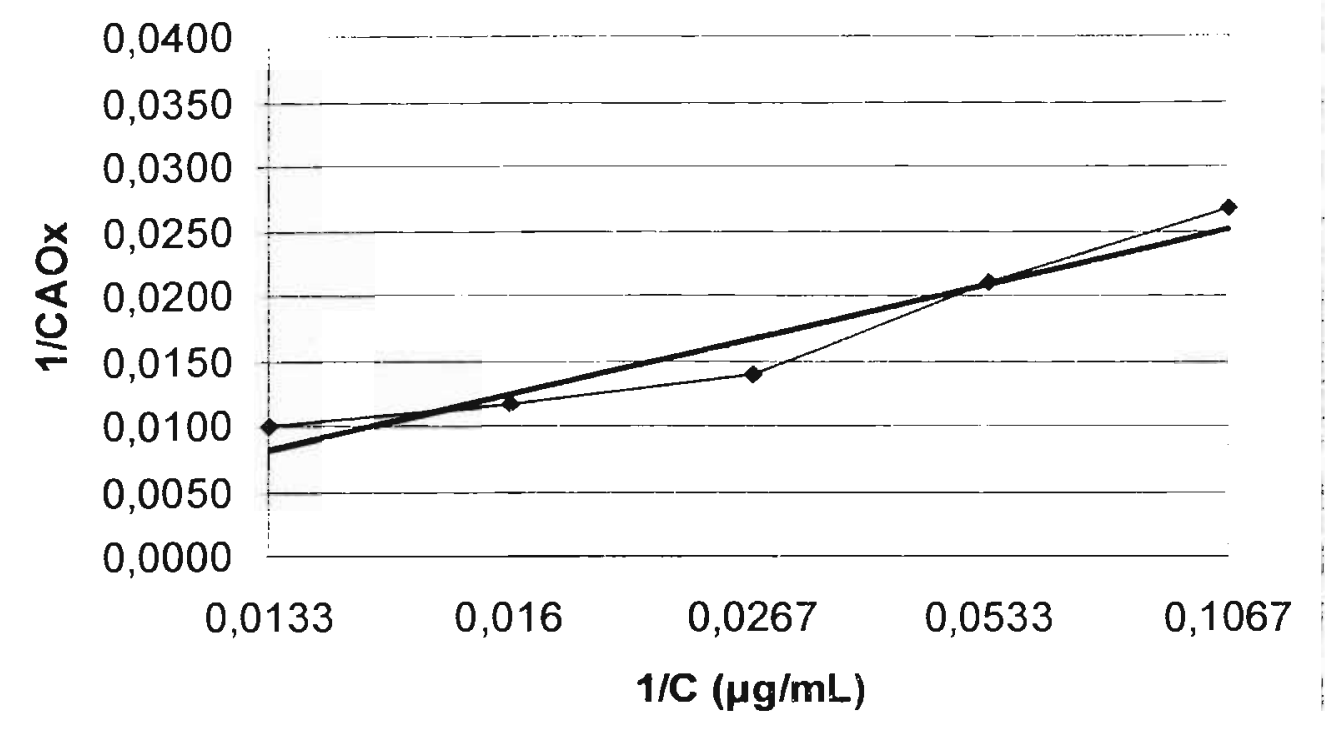

capacidade antioxidante linha de tendência

Figura 27 - Capacidade antioxidante do extrato hidroetanólico liofilizado (EHEL) de Syzygium cumini (L.) Skeels pelo método da formação de MDA em homogenato de cérebro de ratos.

\section{DISCUSSÃO}

\subsection{Generalidades}

O uso de produtos naturais com propriedades farmacológicas é tão antigo quanto a civilização humana e, durante muito tempo, produtos minerais, animais e vegetais foram as principais fontes de medicamentos (DE PASQUALE, 1984).

A Revolução Industrial e o desenvolvimento da Química Orgânica foram responsáveis pelo aumento do uso de produtos sintéticos na farmacoterapia. O desenvolvimento da indústria farmacêutica no início do 
século $X X$ aumentou a descoberta de novos compostos farmacologicamente ativos. A síntese de novos fármacos iniciou obtendo-se pequenas modificações estruturais nas moléculas já conhecidas e desenvolveu-se bem até haver um decréscimo no interesse a partir dos anos 60 , em razão da reflexão de já terem sido isoladas as principais moléculas farmacologicamente ativas das drogas vegetais (SARETT, 1979).

Entretanto, as plantas continuaram sendo amplamente utilizadas: fornecendo alguns compostos cuja sintese é mais onerosa do que a extração; na sintese de fármacos a partir de metabólitos isolados; servindo de triagem para o isolamento de novas moléculas; ou, ainda, na pesquisa quanto a novas propriedades terapêuticas. Como exemplo, a identificação de substâncias ativas contra cânceres humanos está intimamente ligada à triagem de produtos naturais (SHU, 1998).

O estudo, em particular, com a espécie Syzygium cumini surgiu do interesse de trabalho conjunto com um pós-graduando da Unifesp, que abordaria a aplicação do extrato em ratas prenhas hiperglicêmicas.

\subsection{Farmacobotânica}

A familia Myrtaceae reúne espécies de porte arbustivo a arbóreo, folhas opostas, geralmente coriáceas, providas de cavidades secretoras produtoras de óleos voláteis e resinas, reconhecidas na lâmina como pontos translúcidos (METCALFE, CHALK, 1950). Estes caracteres mostram utilidade no reconhecimento de representantes no campo. Kawasaki (1984) destaca o reduzido número de trabalhos com esta família, amplamente distribuída no Brasil, em razão da complexidade taxonômica de suas espécies.

O gênero Syzygium, aclimatado e amplamente distribuído no Brasil, apresenta algumas espécies ornamentais, de frutos édulos, com 
importância medicinal: S. cumini e $S$. jambos. Estas espécies, de hábito e uso medicinal semelhante, são motivo de confusão, mesmo em publicações científicas (TEIXEIRA e colaboradores, 2000).

Embora não seja inscrita na Farmacopéia Brasileira o uso de suas folhas como hipoglicemiante é difundido e motivo de pesquisa de diversos autores (TEIXEIRA e colaboradores, 1997, 2000; PEPATO e colaboradores, 2001).

As caracterizações morfo-anatômica e cromatográfica de $S$. cumini possibilitam a detecção de fraudes e a manutenção da qualidade da droga vegetal e do extrato preparados com suas folhas.

O padrão de venação de $S$. cumini foi classificado como camptódromo broquidódromo, segundo Hickey (1979); classificação coincidente com um dos padrões descritos para a família, por Carr e colaboradores (1986).

As células epidérmicas, em vista frontal, em ambas as faces, apresentam paredes anticlinais retas a ligeiramente sinuosas. Metcalfe e Chalk (1950) citam variações em seus contornos como característica comum à família, mencionando que a posição da célula epidérmica durante o desenvolvimento das folhas pode direcionar a forma de seus contornos.

O par de células epidérmicas que recobrem as cavidades secretoras apresentam a parede comissural de formato variado, desde ligeiramente curvo a denteado. Machado e colaboradores (1988) mencionam células semelhantes em Eugenia sulcata. O número de células que recobrem as cavidades secretoras, bem como o aspecto da parede que as separam, têm mostrado variação entre as mirtáceas. Fontenelle e colaboradores (1994) descrevem estas células dispostas aos pares, isoladas, ou menos freqüentemente, em número de três.

As folhas de jambolão são hipoestomáticas, fato apontado para outras mirtáceas (FERRI, 1971; MACHADO e colaboradores, 1988; AURICCHIO, 2001; MARKMANN, 2002; DONATINI, 2003). Segundo Metcalfe e Chalk 
(1950), estômatos em Myrtaceae são anomocíticos, podendo ocorrer paracíticos em alguns gêneros. Khatijah e colaboradores (1992) consideraram os paracíticos de maior freqüência nas espécies de Eugenia estudadas, observando-se, por vezes, estômatos anisocíticos e anomocíticos. Na espécie em estudo verificaram-se estômatos paraciticos e anomocíticos, predominando estes últimos.

Metcalfe e Chalk (1950) descrevem tricomas em Myrtaceae. Schmid (1972) relata que $5 \%$ das espécies de Syzygium mostram pubescência em órgãos vegetativos e/ou reprodutivos. Esse é um caráter diferencial de espécies de Eugenia. Cerca de $90 \%$ das Eugenia mostram-se pubescentes nos órgãos vegetativos e/ou reprodutivos. A espécie em estudo apresentou-se glabra. Fato em concordância com Schmid (1972) e observado por Donatini (2003) em S. jambos.

O mesofilo dorsiventral, bem como as cavidades secretoras relacionadas às duas faces, observados na espécie coincidem com o padrão descrito para a familia (METCALFE e CHALK, 1950), espécies de Eugenia (MACHADO e colaboradores, 1988; KHATIJAH, 1992; FONTENELLE, 1994; AURICCHIO, 2001) e S. jambos (DONATINI, 2003).

No mesofilo de jambolão reconhece-se o estrato coletor, descrito em outras mirtáceas, tais como, E. sulcata (MACHADO e colaboradores, 1988), E. uniflora (AURICCHIO, 2001) e S. jambos (DONATINI, 2003).

Cavidades secretoras circulares e elípticas, distribuidas junto às duas faces, são relatadas em diversas espécies da familia (FERRI, 1971; MACHADO e colaboradores, 1988; AURICCHIO, 2001; DONATINI, 2003). Essas cavidades são descritas como esquizógenas, esquizolisígenas e lisigenas em Myrtaceae (SCHMID, 1972). No material em estudo encontram-se cavidades secretoras circulares junto às duas faces. Estudos de ontogênese não foram realizados, fato que impossibilita a classificação da estrutura. Gottlieb e Salatino (1987) afirmam que o conteúdo das 
cavidades secretoras, inclusive de mirtáceas, freqüentemente trata-se de óleos voláteis, aos quais pode-se atribuir função de atração de polinizadores e proteção contra predadores.

A presença de cristais de oxalato de cálcio é referida como característica comum em mirtáceas. Drusas em idioblastos arredondados foram observadas no mesofilo, na região floemática e no parênquima cortical do jambolão. Schmid (1972) comenta que cristais prismáticos são pouco freqüentes e ráfides, ausentes, em Syzygium.

Floema interno foi observado na região da nervura mediana. Esse caráter é considerado comum na familia (METCALFE e CHALK, 1950). Os feixes vasculares de médio a grande porte apresentaram-se envolvidos por calotas de células esqlerenquimáticas, geralmente mais desenvolvidas na face abaxial. Metcalfe e Chalk (1950) citam tecidos mecânicos nas proximidades dos feixes vasculares de mirtáceas.

\subsection{Aspectos químicos}

Os vegetais produzem uma grande variedade de substâncias quimicas, sendo algumas delas fundamentais para satisfazer as exigências fundamentais das células. Os carboidratos, proteínas, ácidos graxos e ácidos nucléicos são exemplos desse grupo de substâncias que constituem o metabolismo primário dos vegetais.

Vegetais, microrganismos e, em menor escala, animais, apresentam um arsenal metabólico (enzimas, coenzimas e organelas) capaz de produzir, transformar e acumular inúmeras outras substâncias que, embora não necessariamente essenciais, garantem vantagens para sua sobrevivência e para a perpetuação de sua espécie, em seu ecossistema. Os metabólitos secundários têm ocorrência restrita a alguns grupos taxonômicos, são de baixo peso molecular, possuem grande diversidade estrutural e visam proporcionar 
alguma vantagem para o organismo produtor. Suas funções, a maioria ainda desconhecidas, constituem tema de diversos pesquisadores. Algumas destas substâncias possuem proteção adaptativa significante contra herbívoros e infecções microbianas, além de servirem como atrativo para polinizadores e animais dispersores de sementes. O reconhecimento das propriedades biológicas destes produtos naturais foi importante para que seu estudo fosse direcionado para a pesquisa de novos fármacos, inseticidas e herbicidas (SIMÕES e colaboradores, 2003).

Além disso, o estudo de metabólitos secundários como marcadores químicos em táxons de vegetais e microrganismos vem sendo, cada vez mais, utilizado na identificação de relações existentes entre seres vivos, em qualquer nivel hierárquico: populações, espécies, gêneros, tribos, famílias, etc., bem como em análises evolutivas para avaliar relações filogenéticas e variações dentro de espécies (ZDERO E BOHLMANN, 1990).

É importante ressaltar que diversos fatores como solo, clima e climáticoedáficos são importantes na produção dessas substâncias pelo vegetal. Além disso, a época da colheita, parte da planta coletada, estabilização, secagem, armazenamento, moagem e extração podem ocasionar discrepância nos resultados quando comparados com os obtidos de outros autores (BACCHI, 1996).

A abordagem fitoquímica (Tabela 5) e a análise cromatográfica em camada delgada da droga vegetal e do extrato hidroetanólico liofilizado de jambolão apresentaram resultado positivo para flavonóides (Figuras 10 a 12), taninos e saponinas, confirmando o descrito na literatura. Bhatia e colaboradores (1975) isolaram taninos, Mahmoud e colaboradores (2001) isolaram ácidos fenólicos, taninos e flavonóides e Vaishnava e colaboradores (1992), PDR (2000) e Timbola e colaboradores relataram a presença de miricetina, micricitrina, quercitrina e canferol nas folhas de jambolão. 
A análise cromatográfica em camada delgada é um método rápido, de baixo custo, que permite detectar fraudes e adulterações.

A análise cromatográfica em camada delgada da droga vegetal, do extrato hidroetanólico liofilizado, de suas frações e do EHEL hidrolisado foi efetuada em diversos sistemas cromatográficos, adsorventes e suporte, mas apenas cinco forneceram melhores resultados: acetato de etila/ ácido acético glacial (90:10), $n$-butanol/ácido acético glacial/água destilada (4:1:5), ácido acético a $30 \%(100 \%)$, clorofórmio/acetona/ácido fórmico $(75: 16,5: 8,5)$ e tolueno/acetato de etila (93:7). Os percursos de $15 \mathrm{~cm}$ foram os que forneceram melhor separação dos constituintes.

$\mathrm{Na}$ análise cromatográfica em camada delgada, flavonóides e terpenóides foram detectados na droga e no EHEL, apresentando-se em maior intensidade no segundo. Esta variação pode ser visualizada nos cromatogramas efetuados para a detecção de flavonóides e terpenóides (Figuras 10 a 14).

Pela observação das figuras 11 a 14 notamos manchas comuns nas drogas vegetais colhidas em diferentes estações e que as mesmas encontram-se em concentração ou coloração mais intensa no EHEL. Através dos ensaios realizados, não é possivel identificar os flavonóides presentes, mas apenas detectar sua presença, com exceção à rutina. Na revelação do cromatograma da figura 12 nota-se que o EHEL contém uma mancha correspondente à rutina e que, após hidrólise, é possível visualizar uma mancha correspondente à quercetina no cromatograma.

Pela observação das figuras 11 a 14 notamos manchas comuns nas drogas vegetais colhidas em diferentes estações e que as mesmas encontram-se em concentração ou coloração mais intensa no EHEL. Através dos ensaios realizados, não é possivel identificar os flavonóides presentes, mas apenas detectar sua presença, com exceção à rutina. Na revelação do cromatograma da figura 12 pode-se notar que o EHEL contém rutina e que, após hidrólise, é possível visualizar quercetina no cromatograma. 
A análise cromatográfica em fase gasosa do óleo volátil permitiu verificar a presença de 13 componentes (Tabela 6). Os componentes majoritários coincidem com os encontrados por Lustosa e colaboradores (1999) e Vijayamand e colaboradores (2001). O sistema cromatográfico em camada delgada que evidenciou as substâncias predominantes (Figuras 15 e 16) foi o constituído por tolueno/acetato de etila (93:7)

Após $\circ$ fracionamento do extrato com diferentes solventes, diclorometano, acetato de etila, $n$-butanol e etanol $70 \%$, observa-se que a fração que possui maior probabilidade de possuir substâncias antioxidantes é a fração acetato de etila, que contém a maior quantidade de flavonóides. A fração $n$-butanol também apresentou pequena quantidade de substâncias antioxidantes (Figura 26).

\subsection{Toxicidade aguda}

O registro de qualquer fitoterápico para uso humano necessita de estudos científicos que comprovem a segurança do uso do medicamento, os quais incluem toxicologia pré-clínica e clínica, além da eficácia terapêutica (BRASIL. Resolução RDC n. 17, 2000).

As normas para estudo da toxicidade de produtos fitoterápicos seguem as exigências estipuladas pelo Conselho Nacional de Saúde as quais incluem: toxicidade aguda; toxicidade subaguda e crônica; toxicidade dérmica; e testes complementares. Estes avaliam efeitos adversos sobre a fertilidade e a performance reprodutiva; efeitos adversos sobre fetos e sobre a mãe; mutagenicidade e carcinogenicidade (BRASIL. Resolução CNS n. 196, 1996; BRASIL. Portaria MS/SNVS n. 116, 1996).

O crescente uso de fitoterápicos, aliado à necessidade de regulamentação dos mesmos, mostra maior atenção nas pesquisas na área. $O$ ensaio de toxicidade aguda é um teste preliminar na avaliação da segurança de uso. 
A triagem fitoquímica da droga e do extrato de Syzygium cumini indicou a presença de flavonóides, taninos e saponinas; fato em concordância com a composição química da família. Os taninos, de modo geral, são considerados compostos de atividade tópica, os demais fenólicos, de menor peso molecular, podem sofrer absorção e, assim, ocasionar atividades farmacológicas diversas. Na literatura, poucos representantes deste grupo químico, particularmente os rotenóides (isoflavonóides) são descritos como tóxicos a insetos (BIRCH, 1985). As saponinas mostram toxicidade variável. Administrada por via oral a mamíferos e aves, as saponinas mostraram-se comparativamente atóxicas, embora a ingestão de grandes quantidades tenha provocado anorexia e edema. A ictiotoxicidade é bem conhecida, tendo sido empregada em ensaios de avaliação deste grupo de substâncias (CHEEKE, 1976).

O extrato liofilizado de Syzygium cumini, administrado na dose de $5 \mathrm{~g} / \mathrm{kg}$ de massa corpórea de camundongos não evidenciou alterações indicativas de toxicidade. Não se observaram óbitos de animais durante o experimento, com exceção de uma fêmea do grupo teste, fato que pode ser relacionado à sensibilidade individual ou problemas durante a administração do extrato.

Os parâmetros empregados na avaliação do estudo não apresentaram modificações relevantes. Apenas as fêmeas do grupo teste, durante as 24 horas iniciais, mostraram menor atividade em relação ao grupo controle, fato em discordância quanto aos machos. Nestes últimos, tanto o grupo teste quanto o controle evidenciaram mobilidade semelhante. A massa corpórea das fêmeas do grupo teste mostrou tendência a aumento, após ligeiro período de perda (Figura 18). A massa média do fígado e rins das fêmeas teste era ligeiramente menor (Figura 24). A massa corpórea dos machos do grupo teste evoluiu de maneira semelhante ao grupo controle (Figura 19), e a massa média dos órgãos também evidenciou semelhança com o grupo controle (Figura 25). A análise morfológica dos órgãos dos animais teste não mostrou nenhuma alteração macroscópica em relação 
aos animais controle. Analisando o conjunto destes dados pode-se classificar o extrato ensaiado como de baixa toxicidade aguda ao indivíduo, quando exposto por curto período de tempo, através da via oral, modo de administração empregado na medicina popular.

McGuffin e colaboradores (1997) incluem as cascas e sementes de Syzygium cumini como drogas vegetais que podem ser consumidas sem restriçōes, desde que utilizadas de maneira apropriada. Comparando-se os dados obtidos no presente ensaio com o relatado por estes autores, sugere-se que o extrato preparado com as folhas da espécie pode seguir a mesma classificação sem restrição de uso, desde que consumida de modo adequado.

Os dados apresentados em relação à DL 50 do extrato etanólico a $95 \%$ de sementes de Syzygium cumini (THE EUROPEAN AGENCY FOR THE EVALUATION OF MEDICINAL PRODUCTS, 1999) não são comparáveis ao obtido no ensaio de toxicidade aguda para o extrato em folhas. Os primeiros efetuaram o estudo em camundongos por via oral e parenteral.

\subsection{Atividade antimicrobiana}

A técnica da diluição em meio líquido foi escolhida na determinação da concentração inibitória mínima (CIM). Giesbrecht (1980) cita como vantagens deste método, o maior contato entre o meio de cultura e o microrganismo, sensibilidade e precisão em relação aos métodos de difusão e de bioautografia.

O extrato liofilizado não apresentou atividade bactericida em relação à Escherichia coli e Staphylococcus aureus até a concentração de 1000 $\mu \mathrm{g} / \mathrm{mL}$, enquanto que a CIM para o cloranfenicol foi de $6 \mu \mathrm{g} / \mathrm{mL}$. O tubo, no período de leitura, apresentou líquido límpido, mas residuo de coloração marrom no fundo. A subcultura do mesmo demonstrou a presença de microrganismos viáveis. Verifica-se, no entanto, que o extrato, de algum 
modo, interfere no crescimento bacteriano. O elevado teor de taninos no extrato $(13,97 \%)$ pode estar relacionado com o fato. Em etapa posterior, ensaiando-se uma fração do extrato, isenta de taninos, pode-se reavaliar o resultado. Comparativamente a Chattopadhyay e colaboradores (1998) que encontraram CIM variando de 128 a $2.000 \mu \mathrm{g} / \mathrm{mL}$ frente a diferentes microrganismos empregando o mesmo método com extrato aquoso e etanólico a $95 \%$ de $S$. andamanicum e S. samarangense, o extrato de $S$. cumini pode ser considerado mais ativo. A CIM da ampicilina utilizada neste estudo variou de 2 a $256 \mu \mathrm{g} / \mathrm{mL}$ frente aos microrganismos testados. Embora o extrato de $S$. cumini não mostre resultado promissor para a obtenção de antibióticos potentes para suprir a demanda do mercado, indica a presença de substâncias bioativas. Este ensaio tem sido empregado na busca de compostos com potencial atividade biológica em extratos vegetais (GIESBRECHT, 1980).

A atividade biostática do extrato pode ser relacionada à presença de flavonóides, taninos e saponinas detectadas na triagem fitoquímica (Tabela 5). Estes grupos de substâncias têm apresentado atividade antimicrobiana. Os taninos tem sido empregados há longa data em curtumes de couro em razão de sua propriedade de precipitar proteinas (ROBBERS e colaboradores, 1997). Wätcher e colaboradores (1999) identificaram em Eysenhardtia texana (Fabaceae), duas flavanonas ativas contra Staphylococcus aureus e Candida albicans na concentração de 0,1 mg/mL. Mahato e colaboradores (1988) consideraram saponinas como uma barreira à infecção fúngica. Enzimas proteolíticas secretadas, pelos fungos, em espaços intercelulares de tecidos vegetais, levaram à liberação de saponinas localizadas nos vacúolos celulares.

Os dados obtidos na presente dissertação não são comparáveis aos relatados por Schapoval e colaboradores (1988). Estes autores empregaram o método da difusão em ágar e utilizaram extratos etanólico, acetato de etila, butanólico e óleo volátil. 
A atividade antifúngica empregando-se Candida albicans e Aspergillus niger também não foi apresentou atividade até a concentração de $1000 \mu \mathrm{g} / \mathrm{mL}$.

\subsection{Atividade antioxidante}

Sabe-se que as dietas ricas em frutas e legumes protegem os seres humanos de doenças cardiovasculares, de algumas formas de câncer e diabetes. Este efeito protetor tem sido atribuído à presença de antioxidantes que seriam capazes de reduzir os radicais livres ou espécies reativas de oxigênio (DI CARLO e colaboradores, 1999).

Os diversos órgãos vegetais de S. cumini são empregados no tratamento de diabetes, há longa data.

A diabetes envolve um grupo de transtornos hiperglicêmicos que alteram o metabolismo de carboidratos, lipídeos e proteínas, e associa-se à deficiência de secreção ou ação da insulina (RAO, KESAVULU e APPARAO, 2001). Esta patologia caracteriza-se por complicações que afetam diversos órgãos. Kakkar e colaboradores (1995) consideram que os radicais livres podem estar envolvidos no processo.

Segundo alguns autores (PRINCE e colaboradores, 1998; JORNS, 1999), o aumento na produção de radicais livres através da autooxidação da glicose, durante a hiperglicemia, promove efeitos citotóxicos, resultando na formação de malonildialdeído (PRINCE e colaboradores, 1998; JORNS, 1999).

O termo espécie reativa de oxigênio não inclui apenas radicais centrados no oxigênio como o radical ânion superóxido $\left({ }^{\bullet} \mathrm{O}_{2}\right)$ e $\circ$ radical hidroxila $\left({ }^{\circ} \mathrm{OH}\right)$, mas também não radicalares como peróxido de hidrogênio $\left(\mathrm{H}_{2} \mathrm{O}_{2}\right)$ e o oxigênio singlete $\left({ }^{1} \mathrm{O}_{2}\right)$, entre outros (RÖPKE, 1999). 
Os radicais formados são passíveis de direta ou indiretamente danificar ácidos nucléicos, proteínas e fosfolipídeos de membranas (ABDALLA, 1996).

A fim de neutralizar os efeitos destrutivos dos radicais livres, organismos aeróbicos desenvolveram uma variedade de mecanismos de defesa antioxidante enzimáticos e não enzimáticos. Compostos capazes de inibir reações de radicais livres são usualmente definidos como antioxidantes (ABDALLA, 1996; LARSON, 1997).

Uma substância antioxidante pode ser definida como uma substância química que inibe o processo de oxidação, ou, qualquer substância que, quando presente em baixa concentração, comparada ao do substrato oxidável, diminui ou iribe significativamente a oxidação daquele substrato. Do ponto de vista biológico, antioxidantes são compostos que protegem sistemas biológicos contra os efeitos potencialmente danosos de processos ou reações que promovem a oxidação de macromoléculas ou estruturas celulares (ABDALLA, 1996).

Os constituintes enzimáticos do mecanismo de defesa antioxidante dos organismos incluem as enzimas superóxido dismutase, catalase, glutationa peroxidase, glutationa redutase e glicose-6-fosfato-desidrogenase. Entre os constituintes não enzimáticos temos as vitaminas (alfa-tocoferol, betacaroteno e ácido ascórbico), minerais (manganês, selênio, cobre e zinco), flavonóides e alguns compostos quelantes de ferro de cobre e proteínas (ABDALLA, 1996; RICE-EVANS e colaboradores, 1995; LARSON, 1997; RÖPKE, 1999).

Uma outra linha de defesa antioxidante é a presença de sistemas de reparo do DNA, as proteases e fosfolipases, que atuariam removendo as lesões oxidativas do DNA, proteínas e lipídios (ABDALLA, 1996). 
Os flavonóides possuem um grande potencial para serem agentes antioxidantes devido à sua estrutura química e pela localização na interfase lipídeo/água das membranas celulares (RICE-EVANS e colaboradores, 1995, SAIJA e colaboradores, 1995).

O ensaio de ação antioxidante foi realizado medindo-se a lipoperoxidação do homogenato de cérebro pela formação do MDA. Esse modelo foi o escolhido pois sabe-se que as células cerebrais contêm um alto teor de lipideos, podendo ser assim medida a sua lipoperoxidação ( STOCKS e colaboradores, 1974).

No estudo da formação do MDA, o extrato hidroetanólico liofilizado das folhas de S. cumini dissolvido em etanol $70 \%$ demonstrou possuir atividade antioxidante. 


\section{CONCLUSÕES}

Os principais grupos de metabólitos secundários presentes na droga vegetal e no extrato hidroetanólico foram: flavonóides, saponinas e taninos. Estes constituintes podem ser utilizados como marcadores tanto na padronização da droga vegetal quanto do extrato hidroetanólico liofilizado.

O teor de flavonóides totais variou de 0,53 (verão) a $0,62 \%$ (outono) na droga vegetal e foi de $2,19 \%$ no extrato hidroetanólico liofilizado.

O teor de óleo volátil variou de 0,15 a $0,3 \%$, sendo os constituintes principais o a-pineno (36,54\%), a-terpineol (12,85\%), $\beta$-pineno $(12,74 \%)$ e limoneno $(10,89 \%)$.

O teor de saponinas variou de 4,22 (verão) a $8,64 \%$ (outono) na droga vegetal e foi de $10,92 \%$ no extrato hidroetanólico liofilizado.

O teor de taninos variou de 3,47 (verão) a 4,15\% (outono) na droga vegetal e foi de $13.97 \%$ no extrato hidroetanólico liofilizado.

No ensaio de toxicidade aguda não houve alterações relevantes entre o grupo teste e o grupo controle, demonstrando que o extrato hidroetanólico liofilizado possui baixa toxicidade aguda com a utilização de dose única.

No estudo da formação do MDA, o extrato hidroetanólico liofilizado das folhas de Syzygium cumini dissolvido em etanol $70 \%$ demonstrou possuir atividade antioxidante.

O extrato hidroetanólico liofilizado, em concentração de até $1000 \mu \mathrm{g} / \mathrm{mL}$, não apresentou atividade contra Escherichia coli, Staphyloccccus aureus, Candida albicans e Aspergillus niger com o método da diluição em meio líquido. 


\section{REFERÊNCIAS BIBLIOGRÁFICAS}

ABDALLA, D.S.P. Radicais livres e antioxidantes In: OGA, S. Fundamentos de toxicologia. São Paulo: Atheneu, 1996. cap. 1.4., p.3958.

ACHREKAR, S. KAKLIJ, G.S., POTE, M.S., KELKAR, S.M. Hipiglycemic activity of Eugenia jambolana and Ficus bengalensis: mechanism of action. In vivo, Kapandriti, v.5, n.2, p.143-148, 1991.

ADAMS, R.P. Identification of essential oil components by gas cromatography/mass spectroscopy. Carol Stream: Allured Pub., 1995. $468 p$.

ADILMA, F.O., SCAMPARINI, R.P. Carbohidrates, organic acids and anthocyanin of Eugenia jambolana. Ind. Aliment., v.21, n.4, p.296-298, 1982.

ALMEIDA, E.R. Plantas medicinais brasileiras: conhecimentos populares e científicos. São Paulo: Hemus, 1993 p.212-213.

AURICCHIO, M.T. Estudo farmacognóstico de folhas de Eugenia uniflora. São Paulo, 2001. 128p. (Dissertação de Mestrado - Faculdade de Ciências Farmacêuticas - Universidade de São Paulo).

BACCHI, E.M. Controle de qualidade de fitoterápicos In: DI STASI, L.C. Plantas medicinais: arte e ciência. Um guia interdisciplinar. São Paulo: Editora UNESP, 1996. cap. 12. p.169-186.

BAILEY, L.H. Manual of cultivated plants. New York: Macmillan Publishing Co., 1951. p.724-731.

BALANEHRU, S., NAGARAJAN, B. Intervention of adriamycin induced free radical damage. Biochemistry International, v.28, n.4, p.735-744, 1992.

BARROSO, G.M. Sistemática de angiospermas do Brasil. v.2. São Paulo: Livros Técnicos e Científicos/EDUSP, 1984. p.103-133; 166.

BELLO, A., RODRIGUEZ, M.L., CASTINEIRAS, N., URQUIOLA, A., ROSADO, A., PINO, J.A. Major components of the leaf oil of Eugenia banderensis Urb. J. Essent. Oil Res., Carol Stream, v.7, n.6, p. 697-708, 1995. 
EENENCIA, F., COURREGES, M.C. In vitro and in vivo activity of eugenot on human herpes vírus. Phytotherapy Research, v.14, p.495-500, 2000.

BERLYN, G.P., MIKSCHE, J.P. Botanical microtechnique and cytochemistry. Ames: Iowa State University Press, 1976. p.3-21;91-98.

BHARGAVA, K.K. RAMESHWAR, D., SESHADRI, T.R., Chemical components of E. jambolana stem bark. Current Science, v.43, n.20, p.645-646, 1974.

BHATIA, I.S., BAJAJ, K.L. Chemical constituents of the seeds and bark of Syzygium cumini. Planta Medica, v.28, n.4, p.346-352, $1975 a$.

BHATIA, I.S., BAJAJ, K.L. Thin-layer chromatography of the phenolic constituents of $E$. jambolana seeds. J. Inst. Chem., v.84, p.127-130, 1975b

BIRCHE, N., CROMBIE, L., CROMBIE, W.M. Rotenoids of Lonchocarpus salvadorensis. Phytochemistry, Oxford, v.24, p.2881-2883, 1985.

BRASIL. Portaria n.116/MS/SNVS, de 8 de ago. 1996. Disponível em: http://www.anvisa.gov.br/legis/portarias!116 96.htm . Acesso em: 29 março 2002. [A Secretaria de Vigilância Sanitária propõe norma de estudo da toxicidade e da eficácia de produtos fitoterápicos (anexos I e II)].

BRASIL. Resolução n.196/MS/CNS, de 10 de out. 1996. Disponivel em: http://www.anvisa.gov.br/legis/resol/196 96.htm . Acesso em: 29 março 2002. [O Conselho Nacional de Saúde aprova as diretrizes e normas regulamentadoras de pesquisas envolvendo seres humanos].

BRASIL. Resolução RDC n.17, de 24 de fev. 2000. Disponivel em: http://www.anvisa.gov.br/legis/resol/2000/17 00rdc.htm . Acesso em: 29 março 2002. [A Diretoria Colegiada da Agência Nacional de Vigilância Sanitária aprova o regulamento técnico sobre o registro de medicamentos fitoterápicos junto ao Sistema de Vigilância Sanitária].

BRITO, A.B. Manual de ensaios toxicológicos in vivo. Campinas: Editora da UNICAMP, 1994. p.15-22.

BUKATSCH, F. Bermerkungen zur Doppelfärbung Astrablau-safranin. Mikrokosmos, Stuttgart, v.61, n.8, p.255, 1972.

CARR, D.J. Leaf venation in Eucalyptus and other genera of Myrtaceae. Australian Journal of Botany, v. 34, p. 53-62, 1986.

CHEEKE, P.P. Nutritional and physiological implications of saponins. Nutrition Reports International, Los Altos, v.13, p.315-324, 1976. 
COIMBRA, R. Manual de fitoterapia. 2.ed.Belém: Cejup, 1994. p.170-171.

CORREA, M.P. Dicionário das plantas úteis do Brasil e exóticas cultivadas.v.4. Rio de Janeiro: Imprensa Nacional, 1984. p.429-430.

COSTA, T.R., FERNANDES, O.F.L., SANTOS, S., OLIVEIRA, C.M.A., LIAO, L.M. FERRI, P.H., PAULA, J.R., FERREIRA, H.D., SALES, B.H.N., SILVA, M.D.O.R. Antifungal activity of volatile constituints of Eugenia dysenterica leaf oil. Journal of Ethnopharmacology, Lausane, v.72, n.1-2, p.11-117, 2000.

CRAVEIRO, A.A., ANDRADE, C.H.S., MATOS, F.J.A., ALENCAR, J.W., MACHADO, M.I.L. Essential oil of Eugenia jambolana. Journal of Natural Products. Columbus, v.46, n.4, p.591-592, 1983.

CRONQUIST, A. An integrated system of classification of flowering plants. New York: Columbia University Press, 1981. p.620-627, 639-643.

CRONQUIST, A. The evolution and classification of flowering plants. 2.ed. New York: New York Botanical Garden. 1988. p.263-363;502-511.

DAHLGREN, R.M.T. A revised system of classification of the angiosperms. Botanical Journal of the Linnean Society, London, v.80, p.91-124, 1980.

DAMASCENO, D.C., LIMA, P.H.O., GALHIANE, M.S., VOLPATO, G.T., RUDGE, M.V.C. Revista Brasileira de Plantas Medicinais., v.4, n.2, p.46$54,2002$.

DE LIMA, T.C.M., KLÜEGER, P.A., PEREIRA, P.A., MACEDO-NETO, W.P., MORATO, G.S., FARIAS, M.R. Behavioural effects of crude and semipurified extracts of Syzygium cuminii Linn. Skeels. Phytotherapy Research, v. 12, p. 488-493, 1998.

DE BILLERBECK, V.G., ROQUES, C.G., BESSIERE, J.M. Essential oil on the growth and morphogenesis of Aspergillus niger. Canadian Journal of Microbiology, v.47, p.9-17, 2001.

DE PASQUALE, A. Pharmacognosy: the oldest modern science. Journal of Ethnopharmacology, v.11, p.1-16, 1984.

DELLACASSA, E., LORENZO, D., MONDELLO, L., COTRONEO, A. Uruguayan essential oils. Part. VII. Composition of leaf of Eugenia uruguayensis Camb. var. uruguayensis (Myrtaceae). Journal of Essential Oil Research, Carol Stream, v.9, 1997.

DI CARLO, G., MASCOLO, N. IZZO, A.A., CAPASSO, F. Flavonoids: old and new aspects of a class of natural therapeutic drugs. Life Sciences, 
v.65, n.4, p.337-353, 1999.

DIBBERN, M., KELMANSKY, D., ROMERO. E. Minimal sample for foliar morphology: empirical method and its application in Myrtaceae. Phytomorphology, v.37, n.1, p.87-93, 1987.

DONATINI, R.S. Estudo farmacognóstico e farmacológico de Syzygium jambos (L.) Alston. São Paulo, 2003, 95p. (Dissertação de mestrado Faculdade de Ciências Farmacêuticas - Universidade de São Paulo).

EL-SHABRAWY, A.O. Essential oil composition and tannin contents of the leaves of Eugenia uniflora L. grow in Egypt. Bulletin of the Faculty of Pharmacy, Cairo, v.33, n.3, p.17-21, 1995.

ENGLER, A. Syllabus der pflanzen-familien. Berlin: Gebrüder Borntraeger, 1964. v.II. p. 348-352.

EUROPEAN Pharmacopeia, 3.ed. Suppl. 1. Sainte-Ruffine: Maisonneuve, 2003.

FARMACOPÉIA dos Estados Unidos do Brasil. 2.ed. São Paulo: Siqueira, 1959. p.829, 941-955.

FARMACOPÉIA Brasileira. 4.ed. São Paulo: Atheneu Editora São Paulo Ltda., 1988. pt.1. p.IV-7;V.2.6; V.2.11.

FARMACOPÉIA Brasileira. 4.ed. São Paulo: Atheneu Editora São Paulo Ltda., 1996. pt.2. fascículo 1, 1996. p. 30-2.

FARMACOPÉIA Brasileira. 4.ed. São Paulo: Atheneu Editora São Paulo Ltda., 2000. pt.2. fascículo 2, 2000. p.V.4.1;V.4.2.6;V.4.2.9 e V.4.2.11.

FARMACOPÉIA Brasileira. 4.ed. São Paulo: Atheneu Editora São Paulo Ltda., 2003. pt.2. fascículo 4, 2000. p.191 e 198.

FARNSWORTH, N.R. Biological and phytochemical screening of plants. Journal of Pharmaceutical Science, Washington, v.55, n.3, p.225-276, 1966.

FAVEL, A., STEINMETZ, M.D., REGLI, P. In vitro antifungal activity of triterpenoid saponins. Planta Medica. Stuttgart, v.60, p.50-53, 1994.

FAXING, Z.; PEIYU, L.; QI, Z.; ZHENGIN, Q. Studies on chemical constituents and root of Syzygium buxifolium. Zhonggyo Zhongyao Zazhi, Beijing, v.23, n.3, p. 164-165, 1998. 
FERRI. M.G. Informações sobre transpiração e anatomia foliar de diversas Mirtáceas. Ciência e Cultura, São Paulo, v.23, n.3, p.313-316, 1971.

FONTENELLE, G.B. Foliar anatomy and micromorphology of eleven species of Eugenia. Botanical Journal of the Linnean Society, v.116, n.14, p.111-133, 1994.

GARG, S.C., NIGAM, S.S. Chemical examination of the essential oil from the leaves of Eugenia heyneana L. The Flavour Industry, London, v.1, p.465-468, 1970.

GIESBRECHT, A.M. Atividade antibiótica de produtos naturais. São Paulo, 1980, 64p. (Tese de Livre Docência - Instituto de Ciências Biomédicas Universidade de São Paulo).

GODOY, R.L.O., ALEGRIO, L.V., DUARTE, A.D. Composition analysis of the oil of Eugenia ovalifolia Camb. (Myrtaceae). Journal of Essential Oil Research, Carol Stream, v.11, p.570-572, 1999.

GOTTLIEB, O.R., SALATINO, A. A função e evolução de óleos essenciais e de suas estruturas secretoras. Ciência e Cultura, São Paulo, v.39, n.8, p.707-716, 1987.

GROVER, J.K., RATHI, S.S., VATS, V. Amelioration of experimental diabetic neuropathy and gastropathy in rats following oral administration of plant (Eugenia jambolana, Mucuna pruriens and Tinospora cordifolia) extracts. Indian J. Exp. Biol., v.40, n.3, p.273-276, 2002.

GUPTA, D.R., AGRAWAL, S.K. Chemical examination of the unsaponificable matter of the seed fat of $S$. cumini. Sci. Cult., v.36, n.5, p.298, 1970.

GUPTA, G.S., SHARMA, D.P. Triterpenoid and other constituents of Eugenia jambolana leaves. Phytochemistry, Oxford, v.13, n.9, p.20132014, 1974 .

GUTTERIDGE, J.M.C., HALLIWELL, B. Antioxidants in nutrition, health, and disease. Oxford: Oxford University Press, 1994. 143p.

HARBONE, J.B. Introduction to ecological biochemistry. 3.ed. London: Academic Press, 1988. p277-301.

HARBONE, J.B. Phytochemical methods: a guide to modern techniques of plant analysis. London: Chapman and Hall, 1998. p.40106.

HEYWOOD, V.H. Flowering Plants of the World. Oxford: Oxford 
University Press, 1979. p.161-162.

HICKEY, L.J. A revised classification of the architecture of dicotyledonous leaves. In: METCALFE, C.R., CHALK, L. Anatomy of the dycotyledions: systematic anatomy of leaf and stem, with a brief history of the subject. Oxford: Clarendon Press, 1979. cap. 4, p.25-39.

HOOKER \& JACKSON. Index Kewensis: an enumeration of the genera and species of flowering plants. Oxford: Clarendon Press, 1895. p.904$912 ; 1027-1028$.

HOOKER \& JACKSON. Index Kewensis: an enumeration of the genera and species of flowering plants. supp.8. Oxford: Clarendon Press, 1995. p. 277.

HOWARD, R.A. The petiole. In: METCALFE, C.R., CHALK, L. Anatomy of the dycotyledons: systematic anatomy of leaf and stem, with a brief history of the subject. Oxford: Clarendon Press, 1979. cap. 9, p.88-96.

INVENTÁRIO de plantas medicinais do estado da Bahia. Salvador: SEPLATEC, 1979. p.606-608.

JAIN, M.C., SESHADRI, T.R. Anthocyanins of E. jambolana fruits. Indian J. Chem. Abst., v.13, n.1, p.20-23, 1975.

JOHANSEN, D.A. Plant microtechnique. New York: McGraw-Hill Book Company Inc., 1940. p.3-109.

JOLY, A.B. Botânica: Introdução à taxonomia vegetal. 8ed. São Paulo: Cia. Editora Nacional, 1987.p.219-221;504-509.

JORNS, A. Effect of superoxide dismutase, catalase,chelating agents, and free radical scavengers on the toxicity of alloxan to isolated pancreatic islet in vitro. Free Rad. Biol. Med., v.26, n.10, p.1330-1304, 1999.

JUDD, W.S., CAMPBELL, C.S., KELLOGG, E.A., STEVENS, P.F. Plant systematics: a phylogenetic approach. Sunderland: Sinauer Associates Inc. 1999. p.321-323.

KAKKAR, R. Lipid peroxidation and activity of antioxidant enzymes in diabetic rats. Molecular and Celular Biochemistry, v. 151, p.113-119, 1995.

KAWASAKI, M.L. A familia Myrtaceae na Serra do Cipó, Minas Gerais, Brasil. São Paulo, 1984. p.1-18. (Dissertação de Mestrado - Instituto de Biociências - Universidade de São Paulo). 
KHATIJAH, H.H. Leaf anatomical studies of Eugenia L. species from the Malay Peninsula. Botanical Journal of the Linnean Society, v.110, p.137156, 1992.

LABORATORIES LAROCHE NAVARRON. Hypoglicemic medicament based on S. jambolana (java plum). M.6114(Cl.A.61k), 26 jul 1968, Appl. 91, 714, 19 jan 1967, 4 p. APUD: Chemical Abstracts, v.76, 158336f, 1972.

LANDRUM, L.R., KAWASAKI, M.L. The genera of Myrtaceae in Brazilian illustrated synoptic treatment and identification keys. Brittonia, Bronx, v.49, p. 508-536, 1997.

LARSON, R.A. Naturally occurring antioxidants. Boca Raton: Lewis Publishers, 1997. 195p.

LAWRENCE, G.H.M. Taxonomy of vascular plants. New York: Macmillan Company, 1966. p.634.

LEE, K.G., SHIBAMOTO, T. Inhibition of malonaldehyde formation from blood plasma oxidation by aroma extracts and aroma components isolated from clove and eucalyptus. Food Chem. Toxicology, v.39, n.12, p.1199$1204,2001$.

LEE, M.H.; NISHIMOTO, S.; YANG, L.L.; YEN, K.Y.; HATAN'O, T., YOSHIDA, T.; OKUDA, T. Two macrocyclic hydrolysable tannin dimers from Eugenia uniflora. Phytochemistry, Oxford, v.44, n.7, p. 1343-1349, 1997.

LEGRAND, C.D., KLEIN, R.M. Flora medicinal catarinense. Mirtáceas. Itens 17 a 22. Índice. Itajai: CNPq/IBDF/HBR, 1978. p.835-837; 842-848; 853.

LEWIS, Y.S., DWARAKANATH, C.T., JOHAN, D.S. Acids and sugars in Eugenia jambolana. J. Sci. Research, v.25c, p.280-281, 1956.

LIMA, E.S., ABDALLA, D.S.P. Peroxidação lipídica: mecanismos e avaliação em amostras biológicas. Revista Brasileira de Ciências Farmacêuticas. São Paulo, v.37, n.3, p.293-303, 2001.

LINDE, H. Two phenols from java plum blossorns. Archierves of Pharmacology, Berlin, v.316, n.11, p.971-972, 1983.

MACHADO, R.D., COSTA, C.G. FONTENELLE, G.B. Anatomia foliar de Eugenia sulcata Spring ex Mart. Acta Botanica Brasilica, v.1, n.2, p.275$285,1988$. 
MAIA, J.G.S., ZOGHBI, M.G.B., LUZ, A.I.R. Essential oil of Eugenia punicifolia (HBK) DC. Journal of Essential Oil Research, Carol Stream, v.9, n.3, p.337-338, 1997.

MAHATO, S.B., SARKAR, S.K., PODDAR, G. Triterpenoid saponins. Phytochemistry, Oxford, v. 27, n. 10, p. 3037-3067, 1988.

MARKMANN. B.E.O. Caracterização farmacognóstica de Campomanesia xanthocarpa (Myrtaceae). São Paulo, 2002. 167p. (Dissertação de Mestrado - Faculdade de Ciências Farmacêuticas - Universidade de São Paulo).

MARTINS, R.C.C., ALEGRIO, L.V., CASTRO, R.N., GODOY, R.L.O. Constituents of the essential oil of Eugenia nitida Camb. (Myrtaceae). Journal of Essential Oil Research. Carol Stream, v.11, n.6, p.724-726, 1999.

MATOS, F.J.A. Introdução à fitoquímica experimental. Fortaleza: Edições UFC. 1988.126p.

McGUFFIN, M., HOBBS, C., UPTON, R., GOLDBERG, A. Botanical safety handbook. Boca Raton: CRC Press, 1997. 231p.

McLAFFERTY, F.W., STAUFFER, D.B. The WileyiNBS registry of mass spectral data. New York: John Wiley Sons, 1989. 7872p.

METCALFE, C.R., CHALK, L. Anatomy of the dicotyledons leaves, stem and wood in relation to taxonomy with notes on economic uses. Oxford: at the Clarendon Press, 1950. v.1. p.620-631.

MISSOURI Botanical Garden $w^{3}$ - tropicos. Nomenclatural data base. Disponivel em: http://mobot.mobot.org/cgi-bin/search vast . Acesso em: 24 março 2002.

MORAIS, S.M., CRAVEIRO, A.A., MACHADO, M.I.L., ALENCAR, J.W., MATOS, F.J.A. Volatile constituents of Eugenia uniflora leaf oil from northeastern Brazil. Journal of Essential Oil Research. Carol Stream, v.8, n.4, p.449-451, 1996.

MURUGANANDAN, S., PANT, S., SRINIVASAN, K., CHANDRA, S., TANDAN, S.K., LAL, J., PRAKASH, R.V. Inhibitory role of Syzygium cumini on autacoid-induced inflammation in rats. Indian J. Physiol. Pharmacol., v.46, n.4, p.482-486, 2002.

NAMBA, T., YOSHIZAKI, M., TOMIMORI, T., KOBASHI, K., MITSUI, K., HASE, J. Fundamental studies on the evaluation of the crude drugs. Planta Medica, Stuttgart, v.25, n.1, p.28-38, 1974. 
NARASIMHA-RAO, B.G.V., NIGAM, S.S. Chemical examination of the essential oil from Eugenia jambos Linn. Perf. Essent. Oil Res, Sagar, v.60, p. 282-286, 1969.

NARASIMHA-RAO, B.G.V., NIGAM, S.S., In vitro antimicrobial efficiency of essential oils. Indian J. Med. Res., v.58, n.5, p.627-633, 1970.

NDOUNGA, M., BILALA, J.P., OUABONZI, A. Antibacterial properties of aqueous extracts from Syzygium sp. Fitoterapia. Milan, v.65, n.1, p.80-82, 1994.

NONAKA, G., ISHIMARU, K., WATANABE, M., NISHIOKA, I., YAMAUCHI, T., WAN, A.S.C. Tannins and related compounds. LI Elucidation of the stereochemistry of the triphenoyl moiety in castalagin and vescalagin, and isolation of 1-O-galloylcastalagin from Eugenia grandis. Chemical Pharmaceutical Bulletin, Tokyo, v.35, n.1, p.217-220, 1987.

OLIVEIRA, F., AKISUE, G. Fundamentos de farmacobotânica. $2^{a}$ ed. São Paulo: Atheneu, 2000. 178p.

OLIVEIRA, F., SAITO, M.A. Alguns vegetais brasileiros empregados no tratamento da diabetes. Revista Brasileira de Farmacognosia, São Paulo, v. $2,3,4$, p.170-187, 1987/1989.

PENNA, M. Dicionário brasileiro de plantas medicinais. 3.ed. São Paulo: Livraria Kosmos Ltda, 1946. p.139; 374.

PRATT, D.E., MILLER, E.E. A flavonoid antioxidant in spanish peanuts. Journal of the American Oil Chemists' Society, v.61, n.6, p.1064-1067, 1984.

PRINCE, S.M.P., KAMALAKKANNAN, N., MENON, V.P. Syzygium cumini seed extracts reduce tissue damage in diabetic rat brain. Journal of Ethnopharmacology, Lausanne, v.84, n.2-3, p.205-209, 2003.

PRISTA, L.N., ALVES, A.C., MORGADO, R.M.R. Tecnologia farmacêutica. 4.ed. Lisboa: Fundação Calouste Gulbenkian, 1996. v.2. p.1062-1144.

RAJASEKARAN, M., BAPNA, J.S., LAKSHMANAN, S., NAIR, A.G.R., VELIATH, A.J., PANCHANADAM, M. Antifertility effect in male rats of oleanoic acid, a triterpene from Eugenia jambolana flowers. Journal of Ethnopharmacology, Lausanne, v.24, n.1, p.115-121, 1988.

RANA, N.S., JOSHI, M.N. Investigation on the antiviral activity of ethanolic extracts of Syzygium sp. Fitoterapia. Milan, v.63, n.6, p.542-544, 1992. 
RAO, B.K., KESAVULU, M.M., APPARAO, C.H. Antihyperglicemic activity of Momordica cymbalaria in alloxan diabetic rats. Journal of Ethnopharmacology, Lausanne, v.78, p.67-71, 2001.

RATSIMAMANGA, A.R., LEFOURNIER-CONTENSOU, C., BIBAL-PROT, $P$. Action comparative d'um principe retiré d'écorces de Eugenia jambolana avec le NN-diméthyl biguanide et le glybutamide sur l'hyperglycémie provoquée du rat normal. C.R. Acad. Sc., Paris, v.275, série D, p.913-915, 1972.

RATSIMAMANGA, A.R., LOISEAU, A., URVERG-RATSIMAMANGA: S., BIBAL-PROT, $P$. Nouvelle contribution à l'étude de l'áction d'un principe hypoglycémiant mis en évidence dans l'écorce jeune de Eugenia jambolana (Myrtacées) sur l'hyperglycémie provoquée du lapin normal et poursuite de sa purification. C. R.Acad. Sc., Paris, v.277, série D, p.2219-2222, 1973.

RAY, B.N., PAL, A.K. Estrogenic activity of tree leaves as animal feed. Indian J. Physiol. Allied. Sci., v.20, n.1, p.6-10, 1967.

RICE-EVANS, C.A., MILLER, N.J., PAGANGA, G. Structure-antioxidant activity relationships of flavonoids and phenolic acids. Free Radical Biology \& Medicine, v.20, n.7, p.933-956, 1996.

RIOS, J.L., RECIO, M.C., VILLAR, A. Screening methods for natural products with antimicrobial activity: a review of the literature. Journal of Ethnopharmacology, Lausanne, v.23, p.127-149, 1988.

ROBBERS, J.E., SPEEDIE, M.K., TYLER, V.E. Farmacognosia e farmacobiotecnologia. São Paulo: Editorial Premier, 1997. p.91-162.

ROBLES, C., GARZINO, S. Intraespecific variability in the essential oil composition of Cistus monspeliensis leaves. Phytochemistry, Oxford, v.53, p.71-75, 2000.

ROESER, K.R. Die Nadel der Schwarzkiefer. Massenprodukt und Kunstwek der Natur. Mikrokosmos, Stuttgart, v.61, n.2, p.33-36, 1962.

RÖPKE, C.D. Avaliação da atividade antioxidante de Pothomorphe umbellata Miq. na pele. São Paulo, 1999. 83p. (Dissertação de mestrado. Faculdade de Ciências Farmacêuticas- Universidade de São Paulo).

SAIJA, A., SCALESE, M., LANZA, M., MARZULLO, D., BONINA, F., CASTELLI, F. Flavonoids as antioxidant agents: importance of their interaction with biomembranes. Free Radical Biology and Medicine, New York, v.19, n.4, p.481-486, 1995. 
SANWAL, P.C., SEN, A.K., PAL, A.K. Histochemical studies on alkaline phosphatase activity in uterus of mice on injection of plant estrogens. Indian J. Anim. Sci., v.43, n.4, p.352-354, 1973.

SARETT, L.H. The impact of natural product research on drug discovery. Progress in Drug Research, v.23,p.51-62,1979.

SASS, J.E. Botanical microtechnique. 2.ed. Ames: lowa State College Press, 1951. p.91-98.

SCHAPOVAL, E.E., ALICE, C.B., ZUANAZZI, G.A.A.B., HENRIQUES, A.T. Determinação da actividade antimicrobiana dos extratos de Syzygium cuminii. Revista Portuguesa de Farmácia, Lisboa, v.38, n.4, p. 55-57, 1988.

SCHMEDA-HIRSCHMANN, G. Flavonoids from Calycorectes, Campomanesia, Eugenia and Hexachlamys species. Fitoterapia, Milan, v.66, n. 4 , p. 373-374, 1995.

SCHMEDA-HIRSCHMANN, G., THEODULOZ, C., FRANCO, L., FERRO, B.E., DE-ARIAS, A.R. Preliminary pharmacological studies on Eugenia uniflora leaves: xantine oxidase inhibitory activity. Journal of Ethnopharmacology, Lausanne, v.21, n.2, p.183-186, 1987.

SCHMEDA-HIRSCHMANN, G. Flavonoids from Calycorectes, Campomanesia, Eugenia and Hexachlamis species. Fitoterapia, Milano, v.66, n.4, p. 373-374, 1995.

SCHMID, R. A resolution of the Eugenia-Syzygium controversy (Myrtaceae). American Journal of Botany, v.59, n.4, p.423-436, 1972.

SENGUPTA, P., DAS, P.B. Triterpenoids from flowers of Eugenia jambolana. J. Indian Chem. Soc., v.42, n.8, p.539-542, 1965.

SHARMA, S.B., NASIR, A., PRABHU, K.M., MURTHY, P.S., DEV, G. Hypoglycaemic and hypolipidemic effect of ethanolic extract of seeds of Eugenia jambolana in alloxan-induced diabetic rabbits. Journal of Ethnopharmacology, Lausanne, v.85, n.2-3, p. 201-206, 2003.

SHU, Y.Z. Recent natural products based drug development: a pharmaceutical industry perspective. Journal of Natural Products, v.61, n. 8, p. 1053-1071, 1998.

SILVA, I.K., MILANEZE, M.A. Morfo-anatomia das folhas de Syzygium cumini (L.) Skeels (Myrtaceae). In: SIMPÓSIO BRASILEIRO DE FARMACOGNOSIA, III, Curitiba, 2001. Anais. Curitiba, Sociedade Brasileira de Farmacognosia, s.d.p., p.fb-26. 
SIMÕES, C.M.O., SCHENKEL, E.P., GOSMANN, G., MELLO, J.C.P., MENTZ, L.A., PETROVICK, P.R. Farmacognosia: da planta ao medicamento. 5.ed. Porto Alegre/Florianópolis: Editora da UFRGS/Editora da UFSC, 2003.467-495.

SKEELS, U.S. Dept. Agric. Bur. PI. Ind. Bull. 248: 25. 1912. Apud: MISSOURI Botanical Garden $w^{3}$ - tropicos. Nomenclatural data base. Disponivel em: http://mobot.mobot.org/cgi-bin/search vast . Acesso em: 24 março 2002.

STOCKS, J., GUTTERIDGE, J.M.C., SHARP, R.J., DORMANDY T.L. Assay using brain homogenate for measuring the antioxidant activity of biological fluids. Clinical science and molecular medicine, Oxford, v.47, n.3, p.212222, 1974.

TAHKTAJAN, A.L. Outline of the classification of flowering plants (magnoliophyta). Bot. Rev., v.46, n.3, p.225-359, 1980.

TEIXEIRA, C.C., RAVA, C.A., SILVA, P.M., MELCHIOR, R., ARGENTA, R., ANSELMI, F., ALMEIDA, C.R.C., FUCHS, F.D. Absence of antihyperglycemic effect of jambolan in experimental and clinical models. Journal of Ethnopharmacology, Lausanne, v.71, p.343-347, 2000.

THE EUROPEAN AGENCY FOR THE EVALUATION OF MEDICINAL PRODUCTS. Committee for veterinary medicinal products. Syzygium cumini summary report. 1999. Disponivel em: http://www.eudra.org/emea.html . Acesso em: 29 abril 2002.

THE NATIONAL COMMITTEE FOR CLINICAL LABORATORY STANDARS. Methods for dilution antimicrobial susceptibility test for bacteria that grow aerobically. Approved standard-5.ed. M7-A5. Wayne: NCCLS, 2000 , v.20, n.2, p.1-31.

TIMBOLA, A.K., SZPOGANICZ, B., BRANCO, A., MONACHE, F.D., PIZZOLATTI, M.G. A new flavonol from leaves of Eugenia jambolana. Fitoterapia, v.73, n.2, p.174-176, 2002.

TSAI, I.L., SHEEN, W.S., CHEN, J.J., CHEN, I.S. Isolation of constituents from the leaves of Syzygium tripinnatum. Chin. Pharm. J., Taipei, v.46, n.5, p. 401-4.12, 1994.

USDA, ARS, National Genetic Resources Program. Germplasm Resources Information Network - (GR/N). [Online Database] National Germplasm Resources Laboratory, Beltsville, Maryland. Disponível em: http://www.arsgrin.gov/cgi-bin/npgs/html/splist.pl?11821 Acesso em: 14 abril 2002. 
WÄTCHTER, G.A., HOFFMANN, J.J., FURBACHER, T., BLAKE, M.E. Antibacterial and fungal flavanones from Eysenhardtia texana. Phytochemistry, Oxford, v. 52, p. 1469-1471, 1999.

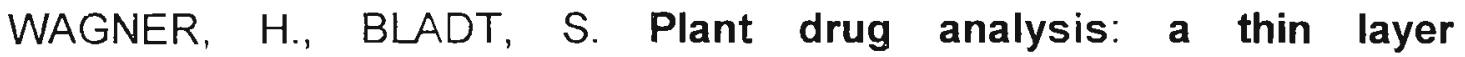
chromatography atlas. 2.ed. Berlin: Springer, 1996. 384p.

WASICKY, R., AKISUE, G. Um aparelho aperfeiçoado para extração de óleos essenciais. Revista da Faculdade de Farmácia e Bioquímica da Universidade de São Paulo, São Paulo, v.7, n.2, p.339-405, 1969.

WEYERSTAHL, P., MARSCHALL-WEYERSTAHL, H., CHRISTIANSEN, C., OGUNTIMEIN, B.O. Volatile constituents of Eugenia uniflora leaf oil. Planta medica. Stuttgart, v.54, n.6, p.546-549, 1988.

ZDERO, C., BOHLMANN, F. Systematics and evolution within the Compositae seen with the eyes of a chemist. Plant Syst. Evol., v.171, p.114, 1990.

ZHENG, G.O., KENNEY, P.M., LAM, L,K.T. Sesquiterpenes from clove (Eugenia caryophyllata) as potential anticarcinogenic agents. Journal of Natural Products, Columbus, v.55, n.7, p.999-1003, 1992. 